Pacific Northwest

National Laboratory

Operated by Battelle for the

U.S. Department of Energy

\title{
Overview of the Flammability of Gases Generated in Hanford Waste Tanks
}

\author{
L. A. Mahoney \\ J. L. Huckaby \\ S. A. Bryan \\ G. D. Johnson
}

July 2000

Prepared for the U.S. Department of Energy under Contract DE-AC06-76RLO 1830 


\title{
DISCLAIMER
}

This report was prepared as an account of work sponsored by an agency of the United States Government. Neither the United States Government nor any agency thereof, nor Battelle Memorial Institute, nor any of their employees, makes any warranty, express or implied, or assumes any legal liability or responsibility for the accuracy, completeness, or usefulness of any information, apparatus, product, or process disclosed, or represents that its use would not infringe privately owned rights. Reference herein to any specific commercial product, process, or service by trade name, trademark, manufacturer, or otherwise does not necessarily constitute or imply its endorsement, recommendation, of favoring by the United States Government or any agency thereof, or Battelle Memorial Institute. The views and opinions of authors expressed herein do not necessarily state or reflect those of the United States Government or any agency thereof.

\author{
PACIFIC NORTHWEST NATIONAL LABORATORY \\ operated by \\ BATTELLE \\ for the \\ UNITED STATES DEPARTMENT OF ENERGY \\ under Contract DE-AC06-76RLO 1830
}

Printed in the United States of America

Available to DOE and DOE contractors from the

Office of Scientific and Technical Information, P.O. Box 62, Oak Ridge, TN 37831;

prices available from (615) 576-8401.

Available to the public from the National Technical Information Service, U.S. Department of Commerce, 5285 Port Royal Rd., Springfield, VA 22161 


\title{
Overview of the Flammability of Gases Generated in Hanford Waste Tanks
}

\author{
L.A. Mahoney \\ J.L. Huckaby \\ S. A. Bryan \\ G.D. Johnson ${ }^{(a)}$
}

July 2000

Prepared for

the U.S. Department of Energy

under Contract DE-AC06-76RLO 1830

Pacific Northwest National Laboratory

Richland, Washington 99352

(a) CH2M Hill Hanford Group, Inc. 


\section{Executive Summary}

This report presents an overview of what is known about the flammability of the gases generated and retained in Hanford waste tanks in terms of the gas composition, the flammability and detonability limits of the gas constituents, and the availability of ignition sources. The intrinsic flammability (or nonflammability) of waste gas mixtures is one major determinant of whether a flammable region develops in the tank headspace; other factors are the rate, surface area, volume of the release, and the tank ventilation rate, which are not covered in this report.

The flammability hazard in Hanford waste tanks was first recognized in the large periodic gas releases that occurred in the double-shell Tank 241-SY-101 (SY-101). In the early 1990s in that tank, periodic spontaneous gas releases resulted when gas that was generated accumulated in a layer of settled solids and made parts of the layer buoyant, causing those regions to break away, rise, and release part of their gas contents to the surface. These buoyant displacement gas release events (BD GREs) are possible only in tanks with deep supernatant layers. This currently includes only double-shell tanks. There are no deep supernatant layers in single-shell tanks, and as a result release events in these tanks have characteristically been small, produced by wastedisrupting activities (such as salt-well pumping) and very localized spontaneous mechanisms.

Waste in the Hanford tanks is generally classified into nonconvective and convective layers. Nonconvective layers contain enough solids to prevent temperature-gradient-driven convection, as shown by nonuniform temperature profiles. Convective layers have uniform temperature profiles and are sufficiently liquid to allow convection. They are called supernatant layers if they lie above a nonconvective layer. In common parlance, nonconvective layer refers to the settled solids on the bottom of a tank or to exceptionally thick floating layers of solids such as those in Tanks A-101 and AX-101. Relatively thin solids layers that float on a convective layer are called crusts. Nonconvective layers can be submerged beneath a supernatant layer or exposed to the headspace, as after salt-well pumping, wherein the upper part of the layer contains little liquid.

Flammable gases are generated in the liquid waste and retained in substantial quantities only in the nonconvective and crust layers. In SY-101, the mechanically mixed slurry layer also contained considerable gas. The flammability of the gases becomes a concern only after large releases to the headspace or to other air-filled volumes such as drill strings. Steady-state releases from the waste produce background concentrations that have been far below flammability. Gases stored in nonconvective layers and crusts are present in isolated bubbles or local networks that are too small to support in situ combustion and lack ignition sources. Though pore networks in the dry upper part of salt-well pumped waste may be large in extent, gases generated in the wet waste below diffuse so rapidly through the pores that flammable concentrations cannot exist there.

The gases that are of most concern in flammability assessment are hydrogen $\left(\mathrm{H}_{2}\right)$, a highly flammable fuel that makes up a large part of the gas in many of the sampled tanks; ammonia $\left(\mathrm{NH}_{3}\right)$, a less flammable and less prevalent fuel; and nitrous oxide $\left(\mathrm{N}_{2} \mathrm{O}\right)$, an oxidant (at sufficiently high temperature). Methane $\left(\mathrm{CH}_{4}\right)$ and other hydrocarbons are highly flammable fuels but present only in negligible concentrations. Nitrogen $\left(\mathrm{N}_{2}\right)$ is an inert gas that tends to 
stifle flammability; water vapor $\left(\mathrm{H}_{2} \mathrm{O}\right)$, is also an inerting agent but present in smaller concentrations than nitrogen. Oxygen $\left(\mathrm{O}_{2}\right)$ is the primary oxidant in the headspace but is not available within the waste. The relative amounts of fuel, oxidant, and inert gas in the waste in a given tank determine the gas flammability. The relative accuracies of the different types of gas composition measurements are important.

A review of the waste gas composition data from headspace samples, retained gas sampler (RGS) samples, drill string samples, and laboratory gas generation studies showed that

- In some cases (AW-101, A-101, and $\mathrm{AN}-103$ ) the $\mathrm{H}_{2} / \mathrm{N}_{2} \mathrm{O}$ ratios measured by $\mathrm{RGS}$ are substantially different for the convective and nonconvective layers. The direction of the difference is not consistent.

- In almost all cases (S-111 and SY-101 are exceptions), the RGS-measured $\mathrm{H}_{2} / \mathrm{N}_{2}$ ratio in the gas retained in the convective layer is between 0.2 and 0.45 .

- The $\mathrm{H}_{2} / \mathrm{N}_{2} \mathrm{O}$ and $\mathrm{H}_{2} / \mathrm{N}_{2}$ ratios of laboratory-generated gases do not consistently match those in gases measured in the waste or in the headspace. The direction of the difference is not consistent.

- The overall composition $\left(\mathrm{H}_{2} / \mathrm{N}_{2} \mathrm{O} / \mathrm{N}_{2}\right)$ of retained gas cannot be determined reliably from drill string samples because the $\mathrm{H}_{2} / \mathrm{N}_{2}$ ratio cannot be measured meaningfully in high-air samples and the $\mathrm{H}_{2} / \mathrm{N}_{2} \mathrm{O}$ ratio does not consistently match RGS values.

The in situ gas composition (plus evaporated ammonia) is most appropriate for assessing the large sudden releases, while the headspace gas composition is appropriate for steady-state conditions. RGS composition data, where available, are preferred to define in situ gas composition because the measurements were made as nearly in situ as possible and contain all the constituents that affect flammability (Barker et al. 1999). However, ammonia released by evaporation should be added to RGS compositions of retained gas to represent the total release composition.

Because the released gas is highly diluted with air, drill string and headspace data lack $\mathrm{N}_{2}$ measurements, which, in most RGS samples, made up 20 to $50 \mathrm{~mol} \%$ of the gas. It follows that $\mathrm{N}_{2} \mathrm{O}$ and $\mathrm{H}_{2}$ together usually made up 50 to $80 \mathrm{~mol} \%$ of the gas, so the absence of $\mathrm{N}_{2}$ data introduces about $25 \%$ uncertainty into estimates of the $\mathrm{H}_{2}$ flammability contribution in the headspace after a large release. A larger uncertainty comes from the fact that the $\mathrm{H}_{2} / \mathrm{N}_{2} \mathrm{O}$ ratios from headspace and drill string measurements often were within about $50 \%$ of the RGS values but could as easily differ by more than a factor of two. Drill string $\mathrm{H}_{2} / \mathrm{N}_{2} \mathrm{O}$ ratios were usually closer to RGS values than were the headspace measurements.

The flammability limits of a combustible mixture are those limiting compositions that will just support flame propagation when stimulated by an external ignition source. Flame propagation in fuel-rich mixtures is limited by oxidant availability and in lean mixtures by fuel availability. Thus the conditions of flammability are characterized by the upper (rich) and lower (lean) flammability limits of fuel gas concentration. In considering the flammability hazard associated with tank wastes, we are concerned more with the lower flammability limit (LFL) than with the upper flammability limit (UFL). The LFL is determined by the gas composition, 
energy and location of the ignition source, direction of flame propagation relative to gravity, and whether the gas is quiescent or being mixed.

Using a large set of data obtained both from the open literature and from experiments with gas mixtures similar to those in the tanks, we calculated both the flammability in air and the selfflammability of the waste gases in RGS-sampled tanks. The conclusions were that

- $\mathrm{H}_{2}$ dominates flammability, even at relatively low concentrations, and flammability limits for $\mathrm{H}_{2}$ in the presence of other fuel gases can be readily calculated.

- The minimum waste gas concentration required to reach the LFL in the tank headspace was calculated for the gases retained in nonconvective layers or crusts in the 14 RGS-sampled tanks. The gas fractions, expressed as the volume fraction of gas in the gas/air mixture, ranged from $5.6 \mathrm{vol} \%$ (for A-101) to $16 \mathrm{vol} \%$ (for U-103).

- Natural inerting (water vapor and waste-gas $\mathrm{N}_{2}$ ) will not prevent combustion in tank headspaces or in the waste itself in every tank;

- Many wastes did not contain sufficient $\mathrm{N}_{2} \mathrm{O}$ oxidant to support combustion in the absence of air. Of the 15 tanks whose nonconvective or crust layers were sampled by RGS, nine contained gas that was not self-flammable, two (AX-101 and AN-104) contained marginally self-flammable gas, and the remaining four (S-102, SX-106, U-103, and SY-101 crust) contained gas that was probably self-flammable.

- Nitrous oxide does not act as an oxidant until the temperature approaches $1000 \mathrm{~K}$. Thus the flammability of waste gas in air near the LFL is not affected by the concentration of nitrous oxide and should not be included in LFL calculation.

When a flammable gas mixture is exposed to an ignition source, the resulting combustion propagation may be either deflagration or detonation. In an open volume, deflagration is possible whenever the gas mixture is between the LFL and the UFL. However, the propagation of deflagration and detonation waves in the pores of a porous medium or a small-diameter pipe depends not only on the gas composition but also on the pore diameter. For assessing Hanford waste, "pore" denotes not only pores between particles but also other, larger cracks and bubble networks. Propagation of detonation in pores, like flame propagation, requires that the pore diameter be greater than a minimum value. The conditions under which detonation can occur (whether in an open space or in pores) are more restrictive than the conditions that permit deflagration.

Deflagration results in subsonic flame propagation away from the ignition site. The peak pressure caused by combustion depends on the completeness of combustion, the resulting adiabatic flame temperature, and the increase (or decrease) in gas moles dictated by the stoichiometry of the combustion reaction. A detonation causes supersonic flame propagation. The peak pressure of a detonation is not uniform throughout an enclosure, as is essentially true for a deflagration, but is localized at the shock wave moving through the gas mixture. For a given gas mixture, a deflagration and a detonation may both release the same amount of energy, but the peak pressure of the detonation shock wave is approximately double that of the deflagration, and the reflection of the shock wave can produce pressures more than twice as high as those in the shock wave itself. 
Deflagration and detonation experiments carried out with gas mixtures similar to those retained in the tanks provided information on which an evaluation of RGS-sampled wastes was based, with the following results:

- The measured peak pressures from deflagrations of waste gases were usually more than four times but less than 10 times the initial pressure in all the measurements made with air as the primary oxidant.

- The presence of $\mathrm{N}_{2} \mathrm{O}$ increased the peak pressures of deflagrations, while $\mathrm{N}_{2}$ significantly reduced the peak pressure.

- Deflagrations are unlikely to propagate within Hanford wastes because retained gas does not appear to take the form of millimeter-diameter pores interconnected in a large network. Creating an ignition source within the waste is also problematic. However, small-scale deflagrations involving fracture bubbles of several $\mathrm{cm}$ extent or bubble networks of up to $1 \mathrm{~m}$ extent cannot be ruled out.

- $\mathrm{NH}_{3}$ and $\mathrm{CH}_{4}$ reduced the detonability of $\mathrm{H}_{2} / \mathrm{N}_{2} \mathrm{O}$ mixtures.

- Fuel-rich mixtures (such as the experimentally simulated gases for AN-103 and A-101) remained potentially detonable in the headspace even when diluted $65 \%$ by air.

- Detonations will not propagate within Hanford wastes; the same conditions that make deflagration unlikely make detonation implausible.

The final consideration in flammability assessment is the ignition energy required to initiate a sustainable combustion. The minimum ignition energy (MIE) is the energy below which the ignition of a combustible mixture cannot occur and above which ignition occurs. The MIE for a gas varies with the composition of the mixture and is orders of magnitude higher at the LFL than at the slightly fuel-rich conditions at which the MIE is a minimum. Experiments with simulated tank waste gas mixtures showed that $0.04 \mathrm{~J}$ sparks were as effective in igniting gas/air mixtures at the LFL as $8 \mathrm{~J}$ sparks.

Friction sparks that result from the impact of two surfaces can serve as an ignition source for flammable gas mixtures but cool quickly and can ignite gases only under very favorable conditions. A study showed that hotspot temperatures achieved by normal or glancing blows were less than the temperature required to ignite hydrogen-air mixtures, that the presence of rust could make ignition more likely, and that stainless steel was one of the most sparking-resistant materials available. The results of this work led to using stainless steel for new components that were placed in SY-101 and other similar tanks. In addition, special tools of copper-beryllium and other low-sparking alloys are being used at Hanford to minimize the danger of sparks in hazardous locations.

Flammable gas mixtures can also be ignited by a heated surface that exceeds the autoignition temperature. However, for the $\mathrm{H}_{2}-\mathrm{N}_{2} \mathrm{O}-\mathrm{NH}_{3}$ mixtures in Hanford tanks, the autoignition temperature would be $457^{\circ}$ to $507^{\circ} \mathrm{C}$. Procedural protections restrict welding and other activities that might produce such high surface temperatures. 
The overall conclusion of this study is that most of the RGS-sampled tanks, and probably most of the tanks at Hanford, contain gas whose composition is such that it can be readily ignited and burned if sufficient gas is released rapidly enough into a tank's headspace. However, it is unlikely that such a deflagration in the headspace will make the transition to a detonation. It is very unlikely that a deflagration could propagate in the retained gas within the waste, and implausible that detonation could be achieved within the waste.

\section{Reference}

Barker SA, WB Barton, DR Bratzel, M Epstein, PA Gauglitz, GD Johnson, SN Maruvada, CE Olson, ML Sauer, SE Slezak, CW Stewart, and J Young. 1999. Flammable Gas Safety Analysis Data Review. SNL-000198, Sandia National Laboratories, Albuquerque, New Mexico. 


\section{Contents}

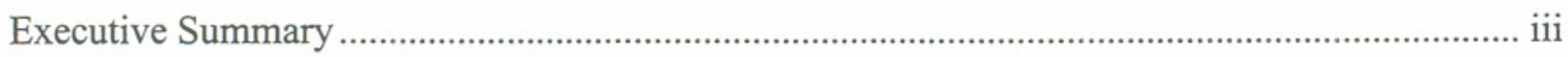

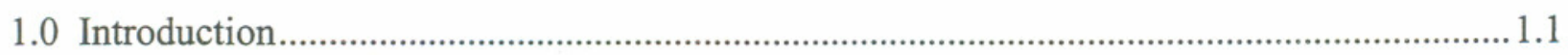

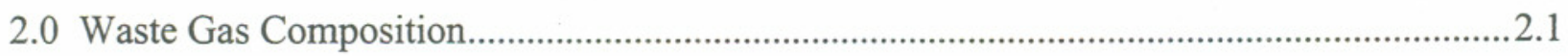

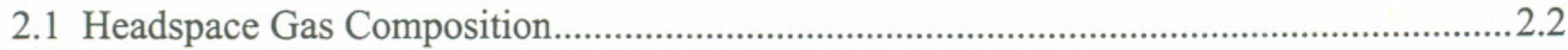

2.1.1 SHMS Cabinet Grab Sample Methods......................................................................... 2.3

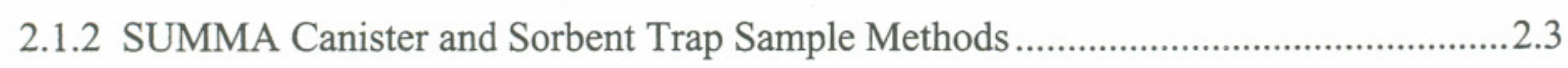

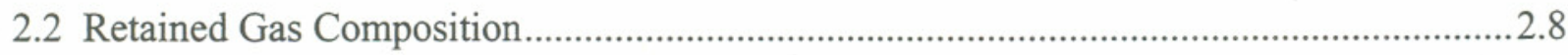

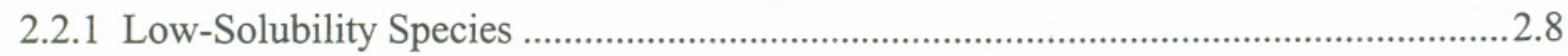

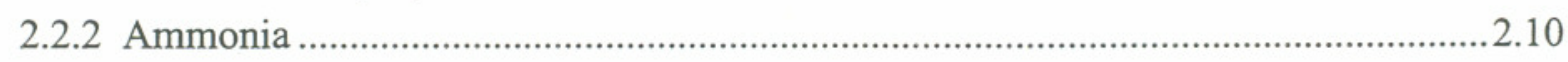

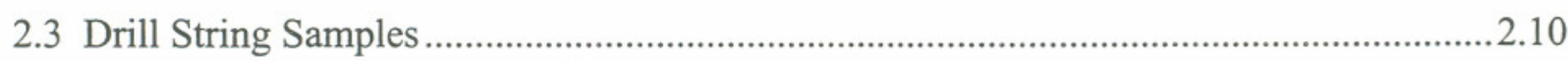

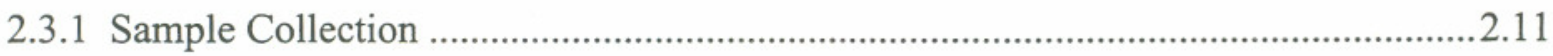

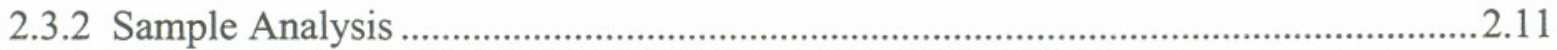

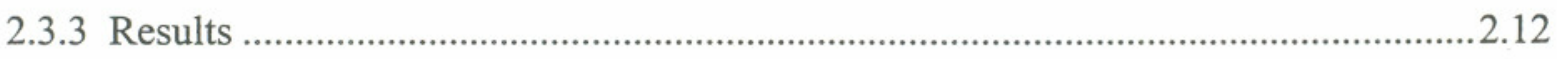

2.4 Waste Sample Gas Composition Derived from Laboratory Tests ....................................2.12

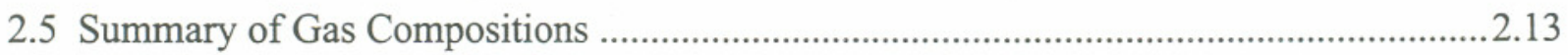

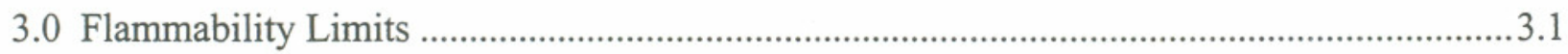

3.1 Flammability of Hydrogen in Air and Nitrous Oxide .......................................................... 3.2

3.2 Flammability of Ammonia in Air and Nitrous Oxide ......................................................... 3.5

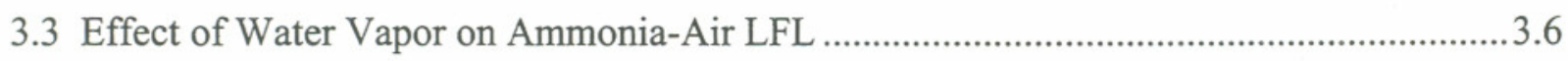

3.4 Methane Flammability in Air and Nitrous Oxide ..............................................................

3.5 Flammability of Hydrogen, Methane, and Ammonia Mixtures in Air .................................

3.6 Self-Flammability of Hydrogen, Methane, Ammonia, and Nitrous Oxide

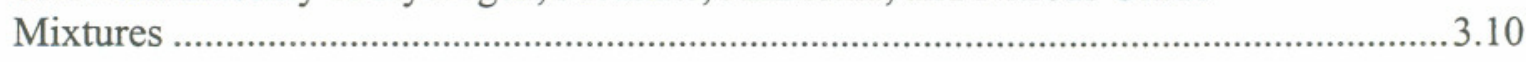

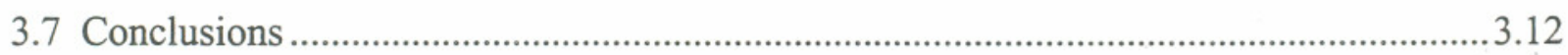

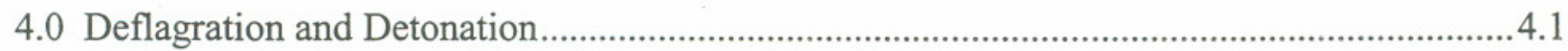

4.1 Deflagration in Open Spaces....................................................................................... 4.1

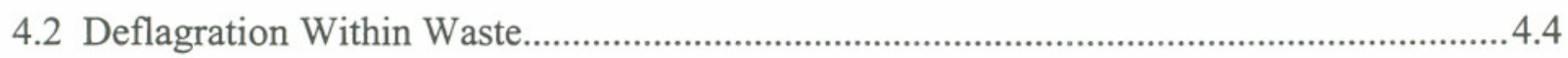

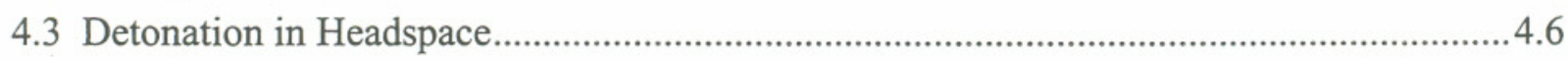

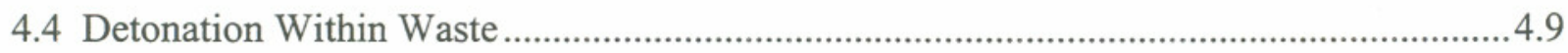

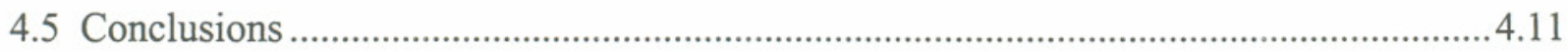

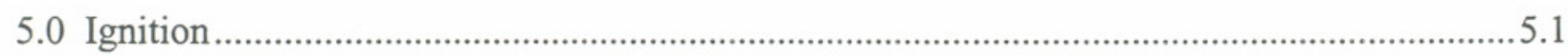

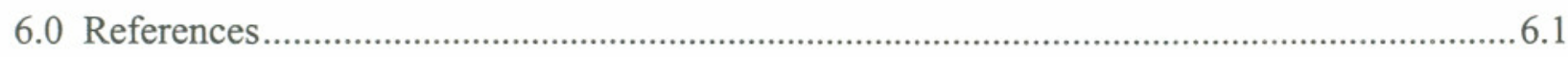




\section{Figures}

3.1 Limits of Flammability of the System $\mathrm{H}_{2}-\mathrm{N}_{2} \mathrm{O}$-Air at $28^{\circ} \mathrm{C}$ and $1 \mathrm{~atm}$................................ 3.3

3.2 Equilibrium Water Vapor Fraction and Ammonia Flammability ....................................... 3.7

4.1 Laminar Burning Velocities for Gas/Air Mixtures ............................................................... 4.2

4.2 Typical Variation of Detonation Cell Widths with Composition ....................................... 4.7

5.1 Typical Relationship Between Stoichiometry and Minimum Ignition Energy .................. 5.2

5.2 Relationship Between Stoichiometry and Minimum Ignition Energy for $\mathrm{H}_{2} / \mathrm{O}_{2} /$ Inert........ 5.2

\section{Tables}

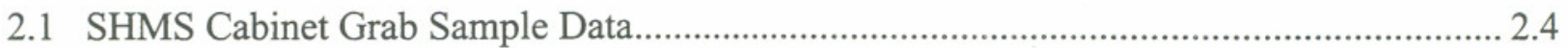

2.2 Headspace Flammable Species Average Concentrations …............................................... 2.5

2.3 Hydrogen Mole Fractions in Retained Gas, from RGS Sampling .................................... 2.9

2.4 Nitrogen Mole Fractions in Retained Gas, from RGS Sampling...................................... 2.9

2.5 Nitrous Oxide Mole Fractions in Retained Gas, from RGS Sampling .............................. 2.10

2.6 Ammonia Mole Fractions in Retained Gas, from Recent RGS Sampling........................ 2.11

2.7 Adjusted Gas Analysis Data from Drill String Samples................................................. 2.12

2.8 Concentrations and Generation Rates of Gases Measured from Waste Samples.............. 2.12

2.9 Comparison of $\mathrm{H}_{2} / \mathrm{N}_{2} \mathrm{O}$ Ratios from RGS, Drill String Samples, SHMS, Vapor Grab Samples and Laboratory Gas Generation Tests ........................................... 2.14

2.10 Comparison of $\mathrm{H}_{2} / \mathrm{N}_{2}$ Ratios from RGS, Drill String Samples, SHMS, Vapor Grab Samples and Laboratory Gas Generation Tests ............................................ 2.15

3.1 Flammability Limits of Hydrogen, Ammonia, and Methane in Air ................................. 3.2

3.2 Flammability Limits of Hydrogen, Ammonia, and Methane in Nitrous Oxide................... 3.2

3.3 Waste Gas Fractions at the LFL in Air/Gas Mixtures ...................................................... 3.9

3.4 Waste Gas Fractions at the LFL in Air/Gas Mixtures ................................................... 3.11

4.1 Minimum Pore Diameter to Allow Deflagration in Pores ................................................... 4.6

4.2 Detonation Cell Widths for Various Dilutions .................................................................. 4.9 


\subsection{Introduction}

The principal flammable products of Hanford waste gas generation reactions are $\mathrm{H}_{2}, \mathrm{~N}_{2} \mathrm{O}$, $\mathrm{NH}_{3}$, and, to a lesser degree, $\mathrm{CH}_{4}$ and other hydrocarbons. These substances have been observed in many laboratory studies with simulants and in laboratory studies with actual waste samples (Ashby et al. 1992, 1993, 1994; Barefield et al. 1995, 1996; Bryan and Pederson 1993, 1994, 1995; Camaioni et al. 1997; Delegard 1980; Johnson 1997; King et al. 1997; Meisel et al. 1991a, 1991b, 1992,1993; Person 1996; Pederson and Bryan 1996). These same products are found in the headspaces of actual waste tanks and in gas samples obtained using the RGS (Johnson 1997; Mahoney et al. 1999). All the gases but $\mathrm{NH}_{3}$ and, to a lesser degree, $\mathrm{N}_{2} \mathrm{O}$ are nearly insoluble in the concentrated, caustic wastes and are found primarily in the gas phase.

The waste gases are often classified by their solubility in the aqueous waste phase and may be divided into low-solubility gases and soluble gases. The low-solubility gases important to flammability are $\mathrm{H}_{2}, \mathrm{~N}_{2} \mathrm{O}$, and $\mathrm{N}_{2} . \mathrm{CH}_{4}$ and other low-solubility hydrocarbons are also permanent but have negligible effect on solubility. Although $\mathrm{N}_{2} \mathrm{O}$ is about 50 times more soluble than the other low-solubility gases, its solubility is so low that less than $15 \%$ of its inventory is dissolved in the liquid. Other low-solubility gases are quantitatively present only as gas. $\mathrm{NH}_{3}$ is the only soluble gas important to flammability with more than $98 \%$ of its inventory present in dissolved form. The relative solubilities of the flammable gases control their forms of release and their effects on headspace flammability. Low-solubility gas releases are dominated by bubble release; soluble gas releases are dominated by direct evaporation from wetted surfaces. $\mathrm{N}_{2} \mathrm{O}$ falls in between but is closer to the other low-solubility gases in behavior. It reaches the headspace predominantly through bubble release, but its headspace concentrations can be significantly affected by evaporation. Thus retained gas compositions can contain lower $\mathrm{NH}_{3}$ and $\mathrm{N}_{2} \mathrm{O}$ fractions than waste gas measured in the headspace, where evaporation also has an effect.

Thus the gases generated and released by the waste are usually mixtures of flammable gases (primarily $\mathrm{H}_{2}$ and $\mathrm{NH}_{3}$ ), a potential oxidant gas $\left(\mathrm{N}_{2} \mathrm{O}\right.$ ), and one or more inert gases (mainly $\mathrm{N}_{2}$ ). Whether a flammable condition develops when gas is released depends on the composition and flammability of the gas mixture, the rate at which it is released, the surface area through which it is released, the total volume released, and the rate of mixing and dilution in the headspace.

This report gathers information from several sources to provide an overview of the flammability of waste gases released into the tank headspaces, focusing on the gas properties that must be considered to assess the risk of a deflagration or detonation of the gases released into the tank headspace. Other documents discuss the additional flammability factors, including the release rates (Stewart et al. 1996; Meyer et al. 1997; Barker et al. 1999), the measured ventilation rates (Huckaby et al. 1997a, 1997b, 1998), and the rate at which the waste gases mix with the air in the headspace (Antoniak and Recknagle 1997; Epstein 1995; Epstein and Burelbach 1998). ${ }^{(a)}$

(a) Antoniak ZI and KP Recknagle, 1995, Modeling of Post-GRE Spatial and Temporal Hydrogen Concentrations in the Tank AW-101 Dome, PNLFG:080295; 1996, Modeling of Post-GRE Spatial and Temporal Hydrogen Concentrations in the Tank AN-105 Dome, WTS FG95.96; Modeling of Hydrogen Plume Concentrations in a Single-Shell Tank Dome, TWSFG96.6; Modeling of Hydrogen Plume Concentrations in Single and Double-Shell Tank Domes, TWSFG96.12. PNNL, Richland, Washington. 
The following are the specific areas covered in this report:

- Waste gas composition data from headspace and retained gas samples (Section 2)

- Flammability limits applicable to $\mathrm{H}_{2} / \mathrm{N}_{2} \mathrm{O} / \mathrm{NH}_{3} /$ air mixtures and to the retained gas in the absence of air (Section 3)

- Deflagration and detonation in the headspace and in the gas retained in the pores of the waste (Section 4)

- Requirements for and availability of ignition sources (Section 5). 


\subsection{Waste Gas Composition}

The waste gas composition measurements that we discuss can be divided into four types based on where the sample was collected:

- the tank headspace

- a waste sample containing trapped gas

- the waste core sampling drill string

- a laboratory gas-generation experiment using waste samples.

Tank headspace sample collection and interpretation are relatively simple and inexpensive. Samples have been collected on a majority of the tanks. By contrast, direct sampling of the gas retained by the waste involves a specialized waste sampling system, the retained gas sampler (RGS), and has been performed successfully on only 14 tanks. Gas samples collected from the drill string of the waste core sampling system have been analyzed for 12 tanks. Like the RGS samples, they provide information on the composition of trapped gas but have large uncertainties due to sampling conditions. Laboratory gas generation tests have been conducted on wastes from six tanks and are the only source of information on the effect of temperature.

Each method has its own limitations, as discussed in this section. Data for retained gas composition and headspace gas composition generally do not agree well. The reason for this is not understood; however, the RGS data are believed to best define the retained gas composition, though there is high uncertainty in the retained ammonia, and thus to best define the composition of the gas released to the headspace during GREs (Barker et al. 1999). The headspace gas composition best defines the flammability for steady-state conditions.

Waste gas released into the tank headspaces is diluted by the air present, so comparisons of headspace waste gas concentrations with results from RGS, drill string, and laboratory tests are typically done by comparing concentration ratios (e.g., $\mathrm{H}_{2} / \mathrm{N}_{2} \mathrm{O}, \mathrm{NH}_{3} / \mathrm{N}_{2} \mathrm{O}, \mathrm{H}_{2} / \mathrm{N}_{2}$, etc.). Ratios involving $\mathrm{N}_{2}$ are not useful because $\mathrm{N}_{2}$ in the tank headspaces (and some of the drill string samples) is overwhelmingly dominated by $\mathrm{N}_{2}$ from air. The waste $\mathrm{N}_{2}$ contribution to the headspace concentration is not measurable. The $\mathrm{H}_{2} / \mathrm{N}_{2} \mathrm{O}$ ratio is particularly useful because it is the dominant fuel/oxidant ratio under airless conditions in gas pockets in the waste, and it tends to be indicative of different waste types. The $\mathrm{H}_{2} / \mathrm{NH}_{3}$ ratio tends not to be useful as a means of comparison, primarily because the ammonia concentration in trapped gas bubbles is essentially in equilibrium with the surrounding waste, while the ammonia concentration in the headspace is controlled by the evaporation rate. However, the headspace $\mathrm{H}_{2} / \mathrm{NH}_{3}$ ratio does indicate to what extent $\mathrm{H}_{2}$ dominates the flammability of headspace gas.

Comparisons of the four types of waste gas composition measurements and their gas concentration ratios are presented and discussed in the following sections. Headspace gas compositions are discussed in Section 2.1, retained gas compositions are discussed in Section 2.2, core sample drill string gas compositions in Section 2.3, and waste sample gas compositions derived from laboratory tests in Section 2.4. 


\subsection{Headspace Gas Composition}

The vast majority of waste gas composition data have come from the tank headspaces or ventilation systems connected to the headspaces. The concentration of a waste gas in a tank headspace at any time is a function of the concentration of the gas at some initial time and the rates of gas release by the waste and ventilation since the initial time. To the extent that the gas release and ventilation rates are constant, the concentrations of waste gases will approach constant (steady state) values.

One limitation of headspace measurements is that no information can be obtained about the release of $\mathrm{N}_{2}$ by the waste. This is because $\mathrm{N}_{2}$ is the principal constituent of air and the change due to released quantities is not measurable; that is, it is a problem of measuring very small changes in a large value. In the context of this report, the $\mathrm{N}_{2}$ present in waste gas releases is primarily of interest because it serves as a diluent.

Another limitation of headspace composition measurements is that headspace gas and vapor concentrations are inherently based on the rates of gas release from the waste surface. They may not be representative of the retained gases within the waste and of the headspace composition after large releases. Gases that are soluble in the aqueous waste are transported to the waste surface via diffusion and convection in the aqueous phase, where they may be released by evaporation into the headspace. Less soluble gases are not efficiently transported by this mechanism; they tend to build up in the retained gas phase and appear when the gas is released. Evidence of differences between headspace and retained gas compositions is discussed in Section 2.5.

A further limitation of headspace composition measurements is that headspace gas and vapor concentrations fluctuate with time. Fluctuations are due principally to changes in temperatures and ventilation rates. Most of the single-shelled tanks (SSTs) are passively ventilated, and the exchange of air between their headspaces and the atmosphere can be affected by changing meteorological conditions. In actively ventilated tanks, which are ventilated by exhaust fans, fluctuations result primarily from changes in fan operation.

Available data suggest that fluctuations of more than about $40 \%$ over a period of months are possible but not common in the passively ventilated tanks. The interpretation of headspace composition data in passively ventilated tanks is further complicated by the fact that cascade line connections and ventilation system piping between tanks can allow significant exchange between the headspaces of adjacent tanks. This leads to potential errors in assuming the gases in a tank's headspace are from the waste in that tank. Exchanges between tanks, evidently via a cascade line, have been observed during tracer ventilation studies. The airflow through the cascade line was also observed to change direction (Huckaby et al. 1998). These limitations notwithstanding, the headspace composition data indicate that levels of flammable gases, including $\mathrm{CH}_{4}$ and $\mathrm{NH}_{3}$, have been lower than their lower flammability limits (LFLs) in air.

Headspace flammable gas composition data have been obtained by two sampling and analytical methods as well as various gas monitoring methods. Gas "grab" samples have been collected routinely using the standard hydrogen monitoring systems (SHMS) mounted on selected tanks (McCain 1999). Gas samples have also been collected from 110 SSTs using 
SUMMA canisters and sorbent traps (PNNL 1999). Various analytical methods have been applied to measure low-solubility gases, $\mathrm{NH}_{3}$, and organic vapors in these samples. Because the laboratory analyses are consistent with and representative of the higher-quality monitoring data, only the laboratory analyses are presented and discussed further in this report.

Monitoring methods range from real-time industrial hygiene "sniffs" to field-installed, datalogged automated analytical systems. Industrial hygiene sniffs are routinely performed to ensure safe working conditions. They are conducted with portable organic vapor monitors (OVMs), organic vapor analyzers (OVAs), combustible gas monitors (CGMs), and colorimetric indicator tubes. The suite of automated instrumentation include Whittaker cells for monitoring $\mathrm{H}_{2}$ concentrations, photoacoustic infrared spectrometers for measuring $\mathrm{NH}_{3}$, a Fourier transform infrared (FTIR) spectrometer that also measures ammonia, and gas chromatographs with thermal conductivity detectors (GC-TCD) for monitoring $\mathrm{H}_{2}, \mathrm{~N}_{2} \mathrm{O}$, and $\mathrm{CH}_{4}$. The monitoring data constitute a large body of information but are of varying quality. Only the laboratory analyses are presented in this report.

\subsubsection{SHMS Cabinet Grab Sample Methods}

Gas grab samples are routinely collected manually from the SHMS cabinets for laboratory analysis. Grab samples are also collected automatically when a high-level alarm is activated by a monitoring instrument. A description of the sampling system and the analytical method is given by McCain (1999). The SHMS grab samples have been analyzed for permanent gases by mass spectrometry at the PNNL Radiochemical Processing Laboratory (RPL).

Table 2.1 lists the 42 double-shelled tanks (DSTs) and SSTs for which SHMS grab samples have been collected, the number of samples analyzed, the average and maximum $\mathrm{H}_{2}$ concentration reported, and the average ratio of $\mathrm{H}_{2}$ to $\mathrm{N}_{2} \mathrm{O}$ in the samples (McCain 1999). The $\mathrm{H}_{2}$ averages include the reported detection limits when no $\mathrm{H}_{2}$ was detected in the sample. The average $\mathrm{H}_{2}$ to $\mathrm{N}_{2} \mathrm{O}$ ratio includes only samples for which both $\mathrm{H}_{2}$ and $\mathrm{N}_{2} \mathrm{O}$ concentrations were above detection limits. "U" is entered when no samples from a given tank met that criterion.

Boldface type indicates that each maximum reported $\mathrm{H}_{2}$ concentrations in $\mathrm{AN}-103, \mathrm{AN}-104$, AN-105, AW-101, and SY-103 is associated with a GRE and was collected automatically by a high-level alarm. Though these GRE-related concentrations are higher than the corresponding averages, they are probably lower than those measured by on-line instruments for the given GRE. Aside from the results associated with GREs, the higher $\mathrm{H}_{2}$ concentrations tend to be associated with passively ventilated SSTs in which breathing rates are highly variable and usually at least an order of magnitude less than in actively ventilated tanks. All of these measured hydrogen concentrations are well below the LFL of hydrogen at $40,000 \mathrm{ppmv}$ in air.

\subsubsection{SUMMA Canister and Sorbent Trap Sample Methods}

Concentrations of permanent gases, inorganic vapors, and organic vapors have been measured in 110 SSTs using SUMMA canister and sorbent trap sampling methods and laboratory analyses. SUMMA canisters are stainless steel vessels with electrochemically passivated internal surfaces that improve the recovery of many organic vapors. SUMMA 
Table 2.1. SHMS Cabinet Grab Sample Data

\begin{tabular}{|c|c|c|c|c|c|}
\hline Tank & Type & $\begin{array}{l}\text { Number } \\
\text { of } \mathrm{H}_{2} \\
\text { Samples }\end{array}$ & $\begin{array}{c}\text { Average } \\
\mathrm{H}_{2} \\
\text { (ppmv) }\end{array}$ & $\begin{array}{l}\text { Average } \\
\mathrm{H}_{2} / \mathrm{N}_{2} \mathrm{O}\end{array}$ & $\begin{array}{c}\text { Maximum } \\
\mathrm{H}_{2} \\
\text { (ppmv) }\end{array}$ \\
\hline A-101 & SST, P & 16 & 801 & 4.8 & 1,540 \\
\hline $\mathrm{AN}-101$ & DST, A & 15 & 10 & $\mathrm{U}$ & 10 \\
\hline $\mathrm{AN}-103$ & DST, A & 62 & 44 & 11 & 800 \\
\hline AN-104 & DST, A & 57 & 27 & 6.2 & 154 \\
\hline AN-105 & DST, A & 35 & 476 & 5.3 & 10,700 \\
\hline AN-107 & DST, A & 20 & 23 & 0.3 & 49 \\
\hline AW-101 & DST, A & 39 & 426 & 43 & 2,980 \\
\hline AX-101 & SST, P & 19 & 48 & 9.6 & 100 \\
\hline AX-103 & SST, P & 9 & 26 & 1.1 & 36 \\
\hline AY-102 & DST, A & 32 & 33 & $\mathrm{U}$ & 73 \\
\hline AZ-101 & DST, A & 6 & 37 & $\mathrm{U}$ & 65 \\
\hline AZ-102 & DST, A & 4 & 98 & $\mathrm{U}$ & 190 \\
\hline BY-103 & SST, P & 18 & 54 & 3.3 & 230 \\
\hline BY-105 & SST, P & 4 & 35 & 0.8 & 69 \\
\hline BY-106 & SST, P & 18 & 143 & 1.9 & 1,110 \\
\hline BY-109 & SST, P & 18 & 36 & 10 & 154 \\
\hline C-106 & SST, A & 2 & 10 & $\mathrm{U}$ & 10 \\
\hline S-101 & SST, P & 6 & 332 & 1.6 & 430 \\
\hline S-102 & SST, P & 12 & 568 & 1.3 & 760 \\
\hline S-106 & SST, P & 5 & 19 & $\mathrm{U}$ & 30 \\
\hline S-107 & SST, P & 6 & 137 & 2.2 & 180 \\
\hline S-108 & SST, P & 2 & 12 & $\mathrm{U}$ & 12 \\
\hline S-109 & SST, P & 4 & 44 & $\mathrm{U}$ & 64 \\
\hline S-111 & SST, P & 21 & 81 & 7.3 & 330 \\
\hline S-112 & SST, P & 22 & 25 & 6.9 & 43 \\
\hline SX-101 & SST, A & 24 & 9 & 3.6 & 33 \\
\hline SX-102 & SST, A & 17 & 17 & 3.5 & 42 \\
\hline SX-103 & SST, A & 24 & 27 & 4.2 & 66 \\
\hline SX-104 & SST, A & 28 & 8 & $\mathrm{U}$ & 28 \\
\hline SX-105 & SST, A & 30 & 22 & 4.3 & 98 \\
\hline SX-106 & SST, A & 25 & 39 & 3.0 & 160 \\
\hline SX-109 & SST, A & 18 & 19 & 4.0 & 69 \\
\hline SY-101 & DST, A & 9 & 14 & 0.9 & 22 \\
\hline SY-102 & DST, A & 15 & 10 & $\mathrm{U}$ & 10 \\
\hline SY-103 & DST, A & 56 & 229 & 2.0 & 1,810 \\
\hline $\mathrm{T}-110$ & SST, P & 21 & 9 & $\mathrm{U}$ & 21 \\
\hline U-102 & SST, P & 4 & 335 & 0.4 & 540 \\
\hline U-103 & SST, P & 21 & 575 & 0.7 & 840 \\
\hline U-105 & SST, P & 18 & 611 & 0.4 & 1,550 \\
\hline U-107 & SST, P & 24 & 390 & 0.8 & 690 \\
\hline U-108 & SST, P & 29 & 379 & 1.0 & 1,060 \\
\hline U-109 & SST, P & 20 & 386 & 0.8 & 630 \\
\hline \multicolumn{6}{|c|}{$\begin{array}{l}\text { DST-double shelled tank; SST-single shelled tank. } \\
\text { A-actively ventilated; P-passively ventilated. } \\
\text { U-less than detection limit. }\end{array}$} \\
\hline
\end{tabular}


canisters used at Hanford were cleaned and evacuated at a laboratory, then filled with air from the tank headspace air via a purged sampling probe. Sorbent traps are pencil-sized tubes packed with sorbent media that remove specific vapors from an air sample passed through them. Sorbent traps were used for ammonia and organic vapors. Generally, tanks have been sampled on a single date from the central portion of the headspace, but some SSTs have been resampled periodically to examine temporal effects (Huckaby et al. 1997a) and from multiple locations to examine headspace homogeneity (Huckaby et al. 1997b). Sampling and analysis methods are described by Huckaby et al. (1996).

Table 2.2 lists the average $\mathrm{NH}_{3}, \mathrm{H}_{2}, \mathrm{CH}_{4}$, and $\mathrm{N}_{2} \mathrm{O}$ concentrations measured in each of the 110 SST headspaces that have been sampled. Also given in Table 2.2 are the $\mathrm{H}_{2} / \mathrm{N}_{2} \mathrm{O}$ ratio, the highest reported total non-methane hydrocarbon (TNMHC) concentration, and the calculated maximum percentage of the LFL in air for each tank.

Table 2.2. Headspace Flammable Species Average Concentrations

\begin{tabular}{|c|c|c|c|c|c|c|c|c|}
\hline & Type & $\begin{array}{c}\mathrm{NH}_{3} \\
\text { (ppmv) }\end{array}$ & $\begin{array}{c}\mathrm{CH}_{4} \\
\text { (ppmv) }\end{array}$ & $\begin{array}{c}\mathrm{H}_{2} \\
\text { (ppmv) }\end{array}$ & $\begin{array}{c}\mathrm{N}_{2} \mathrm{O} \\
(\mathrm{ppmv})\end{array}$ & $\begin{array}{c}\text { Ratio }^{(\mathrm{a})} \text { of } \\
\mathrm{H}_{2} / \mathrm{N}_{2} \mathrm{O}\end{array}$ & $\begin{array}{c}\text { TNMHC } \\
\left(\mathrm{mg} / \mathrm{m}^{3}\right)\end{array}$ & $\begin{array}{c}\text { Max \% of } \\
\text { LFL }^{(c)}\end{array}$ \\
\hline & & $\begin{array}{c}\text { LFL } \\
\text { in air } \\
150,000\end{array}$ & $\begin{array}{c}\text { LFL } \\
\text { in air } \\
50,000\end{array}$ & \begin{tabular}{|c|} 
LFL \\
in air \\
40,000
\end{tabular} & $\mathrm{NA}^{(\mathrm{d})}$ & NA & $\begin{array}{c}\text { LFL } \\
\text { in air } \\
42,000^{(\mathrm{e})}\end{array}$ & NA \\
\hline 241-A-101 & SST, P & 754 & $<12$ & 758 & 218 & 3.5 & 26 & 2.5 \\
\hline 241-A-102 & SST, P & 257 & $<4$ & 297 & 227 & 1.3 & 5.0 & 0.9 \\
\hline 241-A-103 & SST, P & 264 & $<4$ & 474 & 222 & 2.1 & 7.8 & 1.4 \\
\hline 241-A-106 & SST, P & 278 & $<50$ & 120 & 200 & 0.6 & 4.8 & 0.7 \\
\hline $241-A X-101$ & SST, P & 42 & $<12$ & 103 & $<13$ & $>8$ & 3.3 & 0.3 \\
\hline 241-AX-102 & SST, P & 34 & $<12$ & $<98$ & 50 & $<2$ & 12 & 0.3 \\
\hline 241-AX-103 & SST, P & 42 & $<12$ & $<98$ & 24 & $<4$ & 0.5 & 0.3 \\
\hline 241-AX-104 & SST, P & $<14$ & $<110$ & $<100$ & $<100$ & $\mathrm{NA}$ & 1.1 & 0.6 \\
\hline 241-B-102 & SST, P & 5 & $<25$ & $<17$ & 64 & $<0.3$ & 4.2 & 0.1 \\
\hline 241-B-103 & SST, P & 9 & $<54$ & $<44$ & 66 & $<0.7$ & 17 & 0.4 \\
\hline 241-B-105 & SST, P & 6 & $<25$ & $<17$ & 27 & $<0.6$ & 3.8 & 0.1 \\
\hline 241-B-107 & SST, P & 21 & $<25$ & $<17$ & $<17$ & NA & 3.6 & 0.1 \\
\hline 241-B-202 & SST, P & 3 & $<25$ & $<17$ & $<17$ & NA & 0.9 & 0.1 \\
\hline 241-BX-102 & SST, $P$ & 3 & $<25$ & $<17$ & $<17$ & NA & 7.9 & 0.1 \\
\hline 241-BX-103 & SST, P & 91 & $<25$ & 154 & 80 & 1.9 & 55 & 0.6 \\
\hline 241-BX-104 & SST, P & 213 & $<31$ & 91 & 132 & 0.69 & 130 & 0.8 \\
\hline 241-BX-105 & SST, P & 147 & $<25$ & 49 & 117 & 0.42 & 4.4 & 0.3 \\
\hline 241-BX-106 & SST, P & 47 & $<25$ & $<17$ & 44 & $<0.4$ & 2.0 & 0.1 \\
\hline 241-BX-107 & SST, P & 83 & $<4$ & 11 & 12 & 0.92 & 2.4 & 0.1 \\
\hline $241-B X-110$ & SST, $P$ & 63 & $<25$ & $<17$ & $<17$ & NA & 3.8 & 0.2 \\
\hline 241-BX-111 & SST, $P$ & 63 & $<25$ & $<17$ & $<17$ & NA & 11 & 0.2 \\
\hline 241-BY-101 & SST, P & 60 & $<25$ & 29 & 57 & 0.51 & 57 & 0.3 \\
\hline 241-BY-102 & SST, P & 175 & $<4$ & 34 & 18 & 1.9 & 20 & 0.3 \\
\hline 241-BY-103 & SST, P & 30 & $<61$ & 21 & 33 & 0.64 & 13 & 0.4 \\
\hline 241-BY-104 & SST, P & 266 & 8 & 250 & 253 & 1.0 & 207 & 1.4 \\
\hline 241-BY-105 & SST, P & 50 & 4 & 85 & 86 & 1.0 & 18 & 0.3 \\
\hline 241-BY-106 & SST, P & 82 & 3.6 & 55 & 82 & 0.67 & 13 & 0.3 \\
\hline
\end{tabular}


Table 2.2. Headspace Flammable Species Average Concentrations

\begin{tabular}{|c|c|c|c|c|c|c|c|c|}
\hline & Type & $\begin{array}{c}\mathrm{NH}_{3} \\
\text { (ppmv) }\end{array}$ & $\begin{array}{c}\mathrm{CH}_{4} \\
\text { (ppmv) }\end{array}$ & $\begin{array}{c}\mathrm{H}_{2} \\
\text { (ppmv) }\end{array}$ & $\begin{array}{c}\mathrm{N}_{2} \mathrm{O} \\
(\mathrm{ppmv})\end{array}$ & $\begin{array}{c}\text { Ratio }^{(\mathrm{a})} \text { of } \\
\mathrm{H}_{2} / \mathrm{N}_{2} \mathrm{O}\end{array}$ & \begin{tabular}{|c|}
$T_{N M H C}^{(b)}$ \\
$\left(\mathrm{mg} / \mathrm{m}^{3}\right)$
\end{tabular} & $\begin{array}{c}\text { Max \% of } \\
\text { LFL }^{(c)}\end{array}$ \\
\hline 241-BY-107 & SST, P & 972 & NA & 692 & 712 & 1.0 & \begin{tabular}{|r|}
173 \\
\end{tabular} & 1.9 \\
\hline 241-BY-108 & SST, P & 881 & 13 & 431 & 589 & 0.73 & 594 & 2.9 \\
\hline 241-BY-109 & SST, P & 45 & NA & NA & NA & NA & 30 & 0.1 \\
\hline 241-BY-110 & SST, P & 401 & $<61$ & $<160$ & 103 & $<1.6$ & 50 & 1.0 \\
\hline 241-BY-111 & SST, $\mathrm{P}$ & 59 & $<61$ & 67 & 99 & 0.68 & 10 & 0.6 \\
\hline 241-BY-112 & SST, P & 63 & $<61$ & $<94$ & 40 & $<2.4$ & 14 & 0.4 \\
\hline 241-C-101 & SST, P & 99 & 12 & 436 & 643 & 0.68 & 256 & 1.4 \\
\hline 241-C-102 & SST, P & 189 & 5 & 146 & 143 & 1.0 & 313 & 0.9 \\
\hline 241-C-103 & SST, $P$ & 328 & 16 & 776 & 717 & 1.1 & 2139 & 3.5 \\
\hline 241-C-104 & SST, A & 44 & & 70 & 64 & 1.1 & 27 & 0.3 \\
\hline 241-C-105 & SST, A & 2 & & 22 & 5 & 4.4 & 7.5 & 0.1 \\
\hline 241-C-106 & SST, A & 3 & & 10 & 4 & 2.5 & 1.3 & 0.03 \\
\hline 241-C-107 & SST, P & 64 & 3.4 & 455 & 107 & 4.3 & 10 & 3.3 \\
\hline 241-C-108 & SST, P & 3 & 0.3 & 15 & 180 & 0.08 & 1.4 & 0.04 \\
\hline 241-C-109 & SST, P & 10 & 0.93 & 125 & 369 & 0.34 & 1.8 & 0.3 \\
\hline $241-C-110$ & SST, P & 124 & 2 & 12 & 15 & 0.80 & 28 & 0.5 \\
\hline 241-C-111 & SST, P & 3 & 0.5 & 14 & 69 & 0.20 & 1.2 & 0.0 \\
\hline 241-C-112 & SST, P & 23 & 1 & 204 & 544 & 0.38 & 6.3 & 0.5 \\
\hline 241-C-201 & SST, P & $<2$ & $<25$ & $<17$ & $<17$ & NA & 6.3 & 0.1 \\
\hline 241-C-202 & SST, P & $<1$ & $<25$ & $<17$ & $<17$ & NA & 2.5 & 0.1 \\
\hline 241-C-204 & SST, P & 1 & $<25$ & $<17$ & $<17$ & NA & 218 & 0.5 \\
\hline $241-S-101$ & SST, P & 773 & $<25$ & 442 & 271 & 1.6 & 15 & 1.7 \\
\hline $241-S-102$ & SST, P & 600 & 6 & 742 & 701 & 1.1 & 68 & 3.7 \\
\hline $241-S-103$ & SST, P & 150 & $<50$ & 79 & 136 & 0.58 & 13 & 0.4 \\
\hline $241-S-105$ & SST, P & 37 & $<4$ & 21 & 8 & 2.6 & 2.7 & 0.1 \\
\hline 241-S-106 & SST, P & 36 & $<25$ & $<17$ & $<17$ & NA & 9.2 & 0.1 \\
\hline $241-S-107$ & SST, P & 183 & $<25$ & 362 & 91 & 4.0 & 7.1 & 1.1 \\
\hline $241-S-108$ & SST, P & 26 & $<4$ & 22 & 3 & 7.3 & 2.6 & 0.1 \\
\hline 241-S-109 & SST, P & 45 & $<25$ & $<17$ & $<17$ & NA & 3.7 & 0.1 \\
\hline $241-S-110$ & SST, P & 148 & $<4$ & 135 & 40 & 3.4 & 3.8 & 0.5 \\
\hline 241-S-111 & SST, P & 122 & $<23$ & 391 & 48 & 8.1 & 2.0 & 1.1 \\
\hline $241-S-112$ & SST, P & 89 & $<25$ & $<25$ & $<25$ & NA & 8.2 & 0.2 \\
\hline 241-SX-101 & SST, A & 4 & $<25$ & $<25$ & $<25$ & NA & 1.0 & 0.1 \\
\hline 241-SX-102 & SST, A & 16 & $<25$ & $<25$ & $<25$ & NA & 5.6 & 0.2 \\
\hline 241-SX-103 & SST, A & 77 & $<23$ & $<23$ & $<23$ & NA & 1.0 & 0.2 \\
\hline 241-SX-104 & SST, A & 25 & $<25$ & $<25$ & $<25$ & $\mathrm{NA}$ & 1.6 & 0.2 \\
\hline 241-SX-105 & SST, A & 28 & $<25$ & $<25$ & $<25$ & NA & 3.0 & 0.2 \\
\hline 241-SX-106 & SST, A & 179 & $<12$ & $<98$ & 14 & $<7$ & 2.3 & 0.4 \\
\hline 241-SX-107 & SST, A & $<14$ & $<50$ & $<50$ & $<50$ & NA & 0.7 & 0.3 \\
\hline 241-SX-108 & SST, A & $<14$ & $<50$ & $<50$ & $<50$ & NA & 1.1 & 0.3 \\
\hline 241-SX-109 & SST, A & 17 & $<25$ & $<25$ & $<25$ & NA & 1.2 & 0.2 \\
\hline 241-SX-110 & SST, A & $<14$ & $<50$ & $<50$ & $<50$ & NA & 1.0 & 0.3 \\
\hline 241-SX-111 & SST, A & $<14$ & $<50$ & $<50$ & $<50$ & NA & 1.1 & 0.3 \\
\hline 241-SX-112 & SST, A & $<14$ & $<50$ & $<50$ & $<50$ & NA & 1.1 & 0.3 \\
\hline 241-SX-114 & SST, A & $<14$ & $<50$ & $<50$ & $<50$ & NA & 0.9 & 0.3 \\
\hline
\end{tabular}


Table 2.2. Headspace Flammable Species Average Concentrations

\begin{tabular}{|c|c|c|c|c|c|c|c|c|}
\hline & Type & $\begin{array}{c}\mathrm{NH}_{3} \\
\text { (ppmv) }\end{array}$ & $\begin{array}{c}\mathrm{CH}_{4} \\
(\mathrm{ppmv})\end{array}$ & $\begin{array}{c}\mathrm{H}_{2} \\
(\mathrm{ppmv})\end{array}$ & \begin{tabular}{|c|}
$\mathrm{N}_{2} \mathrm{O}$ \\
$(\mathrm{ppmv})$
\end{tabular} & $\begin{array}{c}\text { Ratio }^{(\mathrm{a})} \text { of } \\
\mathrm{H}_{2} / \mathrm{N}_{2} \mathrm{O}\end{array}$ & \begin{tabular}{|c|} 
TNMHC $^{(b)}$ \\
$\left(\mathrm{mg} / \mathrm{m}^{3}\right)$ \\
\end{tabular} & $\begin{array}{c}\operatorname{Max} \% \text { of } \\
\text { LFL }^{\text {(c) }}\end{array}$ \\
\hline 241-T-101 & SST, P & 22 & $<50$ & 52 & $<50$ & $>1.0$ & 0.2 & 0.3 \\
\hline 241-T-104 & ST, P & 105 & $<4$ & 12 & 8 & 1.5 & 1.9 & 0.1 \\
\hline 241-T-107 & ST, P & 125 & $<61$ & $<94$ & 42 & $<2.2$ & 3.9 & 0.5 \\
\hline $241-\mathrm{T}-110$ & ST, P & 108 & $<25$ & $<25$ & $<25$ & NA & 1.1 & 0.2 \\
\hline 241-T-111 & SST, P & 226 & $<61$ & $<94$ & $<13$ & $\mathrm{NA}$ & 24 & 0.6 \\
\hline 241-TX-101 & SST, P & $<14$ & $<50$ & 69 & $<50$ & $>1.4$ & 1.1 & 0.3 \\
\hline 241-TX-102 & SST, P & 170 & $<50$ & $<50$ & 55 & $<0.9$ & 10 & 0.4 \\
\hline 241-TX-103 & SST, P & 108 & $<50$ & $<50$ & 87 & $<0.6$ & 5.2 & 0.3 \\
\hline 241-TX-104 & SST, P & 29 & $<50$ & $<50$ & $<50$ & NA & 1.5 & 0.3 \\
\hline 241-TX-105 & SST, P & 20 & $<61$ & $<99$ & 13 & $<8$ & 5.2 & 0.4 \\
\hline 241-TX-106 & SST, P & 255 & $<150$ & $<50$ & $<50$ & NA & 5.6 & 0.6 \\
\hline 241-TX-108 & SST, P & 25 & $<50$ & $<50$ & $<50$ & NA & 3.8 & 0.3 \\
\hline 241-TX-110 & SST, P & 985 & $<50$ & 160 & 130 & 1.2 & 30 & 1.2 \\
\hline 241-TX-111 & SST, P & 612 & $<25$ & 109 & 177 & 0.62 & 16 & 0.8 \\
\hline 241-TX-112 & SST, P & 113 & $<50$ & $<50$ & $<50$ & $\mathrm{NA}$ & 7.0 & 0.3 \\
\hline 241-TX-113 & SST, P & 22 & $<50$ & $<50$ & $<50$ & NA & 7.7 & 0.3 \\
\hline 241-TX-114 & SST, P & 163 & $<50$ & $<50$ & $<50$ & NA & 11 & 0.4 \\
\hline 241-TX-115 & SST, P & $<14$ & $<50$ & $<50$ & $<50$ & NA & 3.6 & 0.3 \\
\hline 241-TX-116 & ST, P & 14 & $<50$ & $<50$ & $<50$ & NA & 15 & 0.3 \\
\hline 241-TX-117 & SST, P & $<14$ & $<50$ & $<50$ & $<50$ & NA & 4.0 & 0.3 \\
\hline 241-TX-118 & SST, P & 38 & 3 & 78 & 18 & 4.3 & 12 & 0.4 \\
\hline 241-TY-101 & SST, P & 17 & $<12$ & $<93$ & 98 & $<1.0$ & 22 & 0.3 \\
\hline 241-TY-102 & SST, P & 4 & $<4$ & $<3$ & 67 & $<0.04$ & 1.0 & 0.0 \\
\hline 241-TY-103 & SST, P & 44 & $<21$ & 63 & 190 & 0.33 & 95 & 0.4 \\
\hline 241-TY-104 & SST, $\mathrm{P}$ & 59 & $<23$ & $<49$ & 98 & $<0.5$ & 20 & 0.2 \\
\hline 241-TY-105 & SST, P & $<14$ & $<50$ & $<50$ & 51 & $<1.0$ & 35 & 0.3 \\
\hline 241-U-102 & SST, $P$ & 658 & $<50$ & 1100 & 1100 & 1.0 & 10 & 3.3 \\
\hline 241-U-103 & SST, P & 730 & $<61$ & 555 & 878 & 0.63 & 11 & 2.0 \\
\hline 241-U-104 & SST, P & $<1$ & $<25$ & $<17$ & 86 & $<0.2$ & 0.6 & 0.1 \\
\hline 241-U-105 & SST, P & 325 & $<23$ & $<49$ & 154 & $<0.3$ & 4.8 & 0.4 \\
\hline $241-\mathrm{L}$ & SST, P & 931 & $<61$ & 210 & 559 & 0.38 & 17 & 1.3 \\
\hline $241-U-107$ & SST, P & 453 & $<12$ & 500 & 701 & 0.71 & 16 & 1.6 \\
\hline 241-U-108 & SST, P & 692 & $<25$ & 522 & 612 & 0.85 & 12 & 1.9 \\
\hline 241-U-109 & SST, P & 577 & $<25$ & 748 & 868 & 0.86 & 12 & 2.3 \\
\hline 241-U-111 & SST, P & 676 & $<12$ & 247 & 327 & 0.76 & 9.3 & 1.1 \\
\hline 241-U-112 & SST, P & 305 & $<25$ & 142 & 254 & 0.56 & 6.8 & 0.9 \\
\hline 241-U-203 & SST, P & 1 & $<25$ & $<25$ & $<25$ & NA & 11 & 0.1 \\
\hline 241-U-204 & SST, P & .1 & $<25$ & $<25$ & $<25$ & NA & 7.2 & 0.1 \\
\hline \multicolumn{9}{|c|}{$\begin{array}{l}\text { A - actively ventilated. P-passively ventilated. } \\
\text { (a) Calculated from average hydrogen and nitrous oxide concentrations given in columns } 5 \text { and } 6 \text {. } \\
\text { (b) TNMHC = total non-methane hydrocarbons. Value is highest of average EPA Task Order } 12 \text { analysis for } \\
\text { TNMHC, and the average summation of organic species based on gas chromatograph/mass spectral analyses. } \\
\text { (c) \%LFL = Maximum in Tank Characterization Database (PNNL 2000) under vapor flammability results. } \\
\text { (d) NA = not available or not applicable. } \\
\text { (e) LFL of TNMHC in air was based on LFL values for semivolatile alkanes. }\end{array}$} \\
\hline
\end{tabular}


Compared with their LFLs in air, the measured headspace concentrations of all the flammable species are small. Of all the headspace sampling events conducted, the highest calculated flammability was observed for Tank S-102, for which the fuel content reached only about $3.7 \%$ of the LFL. The conclusion to be drawn is that, under normal conditions, the SST headspaces contain far too little fuel to be flammable.

\subsection{Retained Gas Composition}

Direct sampling of the gas retained by the waste has been performed successfully on 14 tanks using the RGS, which is a modified version of the universal core sampler specifically designed to sample gas retained in tank waste. The results of analysis of RGS samples are used to calculate the gas volume fraction and the partition of gas species between the liquid and gas phases under in situ conditions. The major species generally measured are $\mathrm{H}_{2}, \mathrm{NH}_{3}, \mathrm{~N}_{2}, \mathrm{~N}_{2} \mathrm{O}, \mathrm{O}_{2}$, argon, $\mathrm{CH}_{4}$, and other hydrocarbons (a lumped category). The quantity of in situ ammonia is measured with significant uncertainty because of the limitations of the analytical process. Details on the core sampler and modifications and operational constraints of the RGS are contained in Webb (1994).

The analysis of RGS samples is carried out by extruding hermetically sealed core samples into an evacuated sealed container. The gases released by the extruded sample are pumped into collection canisters whose pressure, temperature, and composition are measured, allowing calculation of the amount and composition of the gas in the sample. More detailed descriptions of the experimental procedure may be found in Shekarriz et al. (1997) and Mahoney et al. (1997, 1999). Comprehensive studies were performed to quantify the uncertainty in measuring retained gases using RGS (Cannon and Knight 1995; Cannon 1996).

Gas concentrations are subject to small uncertainties (less than 15\%) for low-solubility species such as $\mathrm{H}_{2}, \mathrm{~N}_{2} \mathrm{O}, \mathrm{N}_{2}$, and $\mathrm{CH}_{4}$ and higher uncertainties (at least 50\%) for $\mathrm{NH}_{3}$. Once the concentration of each species in the sample is determined, the in situ partition of the species between the gas and liquid phases is calculated using the Schumpe gas solubility model. The overall uncertainty in the reported composition of the retained gas (the gas phase) is derived from the uncertainties in both the measured species concentrations and the solubility model.

\subsubsection{Low-Solubility Species}

Tables 2.3, 2.4, and 2.5 show the mole fractions of hydrogen, nitrogen, and nitrous oxide, respectively, in the tanks that have been sampled with the RGS (Mahoney et al. 1999). The tables are arranged by row in chronological order of sampling and are subdivided into columns according to the types of layers from which samples were taken. The average mole fraction for each layer is given, together with the number of samples taken in each layer (in parentheses). Within each cell of the table, the mole percent for a lower-bound solubility is given first with its measurement uncertainty followed by the mole percent for an upper-bound solubility. In some cases, the same mole percent was calculated for both ends of the solubility range, so a single number is presented. 
Table 2.3. Hydrogen Mole Fractions in Retained Gas, from RGS Sampling

\begin{tabular}{|c|c|c|c|}
\hline Tank & $\begin{array}{c}\text { Average in a layer located in } \\
\text { or immediately under surface } \\
\text { solids (mol\%) }\end{array}$ & $\begin{array}{c}\text { Average in a convective or } \\
\text { mixed layer (mol\%) }\end{array}$ & $\begin{array}{c}\text { Average in a settled solids } \\
\text { layer (mol\%) }\end{array}$ \\
\hline A-101 & $70 \pm 7.3-72 \pm 7.0(4)$ & $14 \pm 4.3-15 \pm 4.6(3)$ & \\
\hline AN-103 & $62 \pm 6.4-63 \pm 6.4(1)$ & $19 \pm 12(2)$ & $61 \pm 7.7-62 \pm 7.7(2)$ \\
\hline AN-104 & & $24 \pm 13-26 \pm 15(1)$ & $45 \pm 6.9-47 \pm 7.0(5)$ \\
\hline AN-105 & & $25 \pm 12(1)$ & $59 \pm 5.4-62 \pm 5.4(6)$ \\
\hline AW-101 & & $26 \pm 9.4-25 \pm 9.2(1)$ & $32 \pm 3.2-33 \pm 3.2(5)$ \\
\hline AX-101 & $60 \pm 5.5-64 \pm 5.4(1)$ & & $50 \pm 5.5-51 \pm 5.6(3)$ \\
\hline BY-109 & & & $33 \pm 3.0-34 \pm 3.0(1)$ \\
\hline S-102 & & & $63 \pm 5.7-64 \pm 5.9(4)$ \\
\hline S-106 & & $6.4 \pm 3.4-6.1 \pm 3.3(1)$ & $66 \pm 1-67 \pm 11(4)$ \\
\hline S-111 & & $21 \pm 4.8-18 \pm 4.4(2)$ & $51 \pm 4.7-53 \pm 4.5(5)$ \\
\hline SX-106 & & $26 \pm 8.1-31 \pm 9.5(7)$ & \\
\hline SY-101 & $34 \pm 4.4-40 \pm 4.5(5)$ & & $23 \pm 1.4(4)$ \\
\hline U-103 & & & $25 \pm 3.0-26 \pm 3.1(4)$ \\
\hline U-109 & & & \\
\hline
\end{tabular}

Table 2.4. Nitrogen Mole Fractions in Retained Gas, from RGS Sampling

\begin{tabular}{|c|c|c|c|}
\hline Tank & $\begin{array}{c}\text { Average in a layer located in } \\
\text { or immediately under } \\
\text { surface solids (mol\%) }\end{array}$ & $\begin{array}{c}\text { Average in a convective or } \\
\text { mixed layer (mol\%) }\end{array}$ & $\begin{array}{c}\text { Average in a settled } \\
\text { solids layer (mol\%) }\end{array}$ \\
\hline A-101 & $19 \pm 4.9(4)$ & $60 \pm 22-71 \pm 27(3)$ & $33 \pm 4.3(2)$ \\
\hline AN-103 & $29 \pm 3.2(1)$ & $68 \pm 61-75 \pm 68(2)$ & $29 \pm 4.8-31 \pm 5.0(5)$ \\
\hline AN-104 & & $55 \pm 48-63 \pm 57(1)$ & $24 \pm 4.0(6)$ \\
\hline AN-105 & & $57 \pm 41-64 \pm 47(1)$ & $55 \pm 6.2-57 \pm 6.3(5)$ \\
\hline AW-101 & & $67 \pm 32-69 \pm 33(1)$ & $28 \pm 5.0-29 \pm 5.1(3)$ \\
\hline AX-101 & $16 \pm 2.6-18 \pm 2.7(1)$ & & $32 \pm 4.3-33 \pm 4.4(4)$ \\
\hline BY-109 & & & $25 \pm 3.7-26 \pm 3.8(4)$ \\
\hline S-102 & & & $21 \pm 5.6-22 \pm 5.7(4)$ \\
\hline S-106 & & $90 \pm 68-91 \pm 69(1)$ & $20 \pm 4.0-21 \pm 4.0(5)$ \\
\hline S-111 & & $61 \pm 20-76 \pm 25(2)$ & \\
\hline SX-106 & & $40 \pm 14-48 \pm 16(7)$ & $36 \pm 2.3-37 \pm 2.3(4)$ \\
\hline SY-101 & $27 \pm 4.5-32 \pm 4.9(5)$ & & $46 \pm 7.7-47 \pm 8.0(4)$ \\
\hline U-103 & & & \\
\hline U-109 & & & \\
\hline
\end{tabular}


Table 2.5. Nitrous Oxide Mole Fractions in Retained Gas, from RGS Sampling

\begin{tabular}{|c|c|c|c|}
\hline Tank & $\begin{array}{c}\text { Average in a layer located in } \\
\text { or immediately under } \\
\text { surface solids (mol\%) }\end{array}$ & $\begin{array}{c}\text { Average in a convective or } \\
\text { mixed layer (mol\%) }\end{array}$ & $\begin{array}{c}\text { Average in a settled solids } \\
\text { layer (mol\%) }\end{array}$ \\
\hline A-101 & $5.7 \pm 0.6-5.5 \pm 0.5(4)$ & $15 \pm 5.4-6.0 \pm 2.2(3)$ & \\
\hline AN-103 & $6.9 \pm 0.7-6.3 \pm 0.6(1)$ & $8.3 \pm 5.3-2.6 \pm 1.7(2)$ & $4.2 \pm 0.6-3.6 \pm 0.5(2)$ \\
\hline AN-104 & & $15 \pm 8.4-5.2 \pm 3.1(1)$ & $23 \pm 3.8-20 \pm 3.3(5)$ \\
\hline AN-105 & & $13 \pm 6.6-4.6 \pm 2.4(1)$ & $15 \pm 1.5-12 \pm 1.2(6)$ \\
\hline AW-101 & & $2.3 \pm 0.8-0.8 \pm 0.3(1)$ & $7.5 \pm 0.8-5.1 \pm 0.6(5)$ \\
\hline AX-101 & $11 \pm 1.1(1)$ & & $18 \pm 2.5-17 \pm 2.3(3)$ \\
\hline BY-109 & & & $33 \pm 3.3-32 \pm 3.0(4)$ \\
\hline S-102 & & & $11 \pm 1.0-9.0 \pm 0.9(4)$ \\
\hline S-106 & & $2.2 \pm 1.3-0.9 \pm 0.6(1)$ & $11 \pm 1.8-10 \pm 1.6(4)$ \\
\hline S-111 & & $15 \pm 4.2-2.8 \pm 0.8(2)$ & $24 \pm 2.7(5)$ \\
\hline SX-106 & & $24 \pm 7.4-16 \pm 4.9(7)$ & \\
\hline SY-101 & $19 \pm 2.5-22 \pm 2.4(5)$ & & $40 \pm 2.4-38 \pm 2.3(4)$ \\
\hline U-103 & & & $27 \pm 3.6-25 \pm 3.4(4)$ \\
\hline U-109 & & & \\
\hline
\end{tabular}

\subsubsection{Ammonia}

Ammonia is a highly soluble species. Little of the sample $\mathrm{NH}_{3}$ is present in the gas extracted from RGS samples by the analytical methods that have been used; most of it remains dissolved in the sample liquid. To determine the residual dissolved $\mathrm{NH}_{3}$, it is necessary to either measure it directly or find a physical relationship by which the residual $\mathrm{NH}_{3}$ can be calculated from the extracted $\mathrm{NH}_{3}$. Both alternatives are technically problematic, and the actual relationship between the extracted $\mathrm{NH}_{3}$ vapor and the dissolved residual $\mathrm{NH}_{3}$ is difficult to determine. Therefore, the uncertainty in ammonia concentrations is estimated as at least $50 \%$. See Mahoney et al. (2000) for a detailed discussion of ammonia extraction procedures, analysis methods, and the resulting uncertainties. The $\mathrm{NH}_{3}$ mole fractions in the retained gas are given in Table 2.6.

\subsection{Drill String Samples}

Drill string samples are grab samples taken from the gas volume in the drill string during tank waste core drilling operations. The primary purpose of drill string samples is to ensure safe working conditions during core drilling. Under certain circumstances, these samples also provide data on gases retained in the tank waste. Siciliano (1998) provides a detailed description of the process of extracting data relevant to characterizing retained gases from this type of sample. These data provide approximate retained gas information on tanks not sampled with the more refined RGS method. 
Table 2.6. Ammonia Mole Fractions in Retained Gas, from Recent RGS Sampling

\begin{tabular}{|l|c|c|c|}
\hline Tank & $\begin{array}{c}\text { Average in a layer located in } \\
\text { or immediately under } \\
\text { surface solids (mol\%) }\end{array}$ & $\begin{array}{c}\text { Average in a convective or } \\
\text { mixed layer (mol\%) }\end{array}$ & $\begin{array}{c}\text { Average in a settled } \\
\text { solids layer (mol\%) }\end{array}$ \\
\hline A-101 & $4.8 \pm 1.8-1.8 \pm 0.7(4)$ & $7.8 \pm 4.0-3.0 \pm 1.5(3)$ & \\
\hline AN-103 & $1.8 \pm 0.8-0.6 \pm 0.3(1)$ & $1.2 \pm 0.9-0.5 \pm 0.4(2)$ & $0.9 \pm 0.4-0.3 \pm 0.1(2)$ \\
\hline AN-104 & & $1.0 \pm 0.7-0.4 \pm 0.3(1)$ & $1.4 \pm 0.7-0.5 \pm 0.3(5)$ \\
\hline AN-105 & & $0.8 \pm 0.5-0.4 \pm 0.2(1)$ & $0.6 \pm 0.3-0.3 \pm 0.1(6)$ \\
\hline AW-101 & & $0.6 \pm 0.3-0.2 \pm 0.1(1)$ & $0.9 \pm 0.4-0.3 \pm 0.2(5)$ \\
\hline AX-101 & $9.1 \pm 2.1-3.5 \pm 0.8(1)$ & & $0.3 \pm 0.1-0.1 \pm 0.06(3)$ \\
\hline BY-109 & & & $1.0 \pm 0.3-0.4 \pm 0.1(4)$ \\
\hline S-102 & & & $0.4 \pm 0.2-0.2 \pm 0.1(4)$ \\
\hline S-106 & & $0.1 \pm 0.1(1)$ & $1.0 \pm 0.3-0.5 \pm 0.2(4)$ \\
\hline S-111 & & $0.6 \pm 0.1-0.2 \pm 0.05(2)$ & $4.4 \pm 0.9-1.6 \pm 0.4(5)$ \\
\hline SX-106 & & $7.1 \pm 2.2-2.3 \pm 0.7(7)$ & \\
\hline SY-101 & $19 \pm 4.7-4.9 \pm 1.2(5)$ & & $0.6 \pm 0.3-0.3 \pm 0.1(4)$ \\
\hline U-103 & & & $0.9 \pm 0.3-0.4 \pm 0.2(4)$ \\
\hline U-109 & & & \\
\hline
\end{tabular}

\subsubsection{Sample Collection}

The drill string is the passageway through which core samplers are lowered into the waste and cores are retrieved. Vapors or gases that are released from the waste during the drilling are contained in the headspace of the drill string. Drill string samples potentially contain gas originating in more than one core sample or layer so do not provide a definite basis for making distinctions between the gas composition in different layers.

During the tank waste coring operation, hazardous gas monitoring is used to verify that hazardous gases in the drill string are below specified safety limits. When the limits are exceeded, a grab sample may be collected for later laboratory analysis. In addition, the drill string headspace may be purged with argon or $\mathrm{N}_{2}$ or air may be admitted to the drill string. Thus, subsequent grab samples can contain residual purge gas or air, which complicates the interpretation of results. The sample containers sometimes also contain residual helium from their preparation.

\subsubsection{Sample Analysis}

The samples were analyzed using mass spectrometry at the RPL. Because oxygen, argon, and helium are not produced in the waste, the measured amounts of these gases were assumed to be residuals from either the sample container preparation or drill string purging and were used to correct for air/purge gas contamination. Siciliano (1998) provides the details of data correction. 


\subsubsection{Results}

Table 2.7 lists the 16 drill string samples collected and the concentrations of the primary gases in each sample. Ammonia is not listed because, as in the case of SHMS grab samples, the sampling methods and devices did not allow this species to be properly measured. Table 2.7 also lists the calculated ratios of $\mathrm{H}_{2}$ to $\mathrm{N}_{2}$ and $\mathrm{H}_{2}$ to $\mathrm{N}_{2} \mathrm{O}$.

Table 2.7. Adjusted Gas Analysis Data from Drill String Samples

\begin{tabular}{|c|c|c|c|c|c|c|c|}
\hline Tank & $\begin{array}{c}\mathrm{H}_{2} \\
(\mathrm{~mol} \%)\end{array}$ & $\begin{array}{c}\mathrm{CH}_{4} \\
(\mathrm{~mol} \%)\end{array}$ & $\begin{array}{c}\mathrm{N}_{2} \\
(\mathrm{~mol} \%)\end{array}$ & $\begin{array}{c}\mathrm{N}_{2} \mathrm{O} \\
(\mathrm{mol} \%)\end{array}$ & $\begin{array}{c}\text { Other } \\
(\mathrm{mol} \%)\end{array}$ & $\begin{array}{c}\mathrm{H}_{2} / \mathrm{N}_{2} \mathrm{O} \\
\text { Ratio }\end{array}$ & $\begin{array}{c}\mathrm{H}_{2} / \mathrm{N}_{2} \\
\text { Ratio }\end{array}$ \\
\hline AN-103 & 47.5 & 0.203 & 47.1 & 5.15 & 0.33 & 9.2 & 1.01 \\
\hline AN-104 & 33.3 & 0.897 & 53.9 & 11.2 & 0.56 & 3.0 & 0.62 \\
\hline AW-101 & 25.4 & & 72.6 & 2.03 & & 12.5 & 0.35 \\
\hline B-203 & 3.10 & 0.0020 & 96.7 & & 0.28 & & 0.03 \\
\hline BY-109 & 32.4 & 0.57 & 56.9 & 9.65 & 1.1 & 3.4 & 0.57 \\
\hline BY-110 & 35.2 & 1.22 & $39.0^{(a)}$ & 21.8 & 2.9 & 1.6 & 0.90 \\
\hline S-102 & 25.8 & 0.201 & $58.7^{(a)}$ & 15.4 & & 1.7 & 0.44 \\
\hline S-102 & 36.7 & & $60.5^{(a)}$ & 2.98 & & 12.3 & 0.61 \\
\hline S-106 & 41.7 & & 47.7 & 10.4 & 0.24 & 4.0 & 0.87 \\
\hline S-106 & 64.9 & 0.176 & 23.6 & 10.3 & 0.38 & 6.3 & 2.75 \\
\hline S-107 & 19 & 0.0308 & 75.9 & 2.52 & 1.45 & 7.6 & 0.25 \\
\hline SX-106 & 2.31 & 0.015 & 96.6 & 0.924 & 0.12 & 2.5 & 0.02 \\
\hline SY-102 & 2.42 & 0.015 & 96.9 & 0.307 & 0.23 & 7.9 & 0.02 \\
\hline U-109 & 41.0 & 0.171 & $50.7^{(\mathrm{a})}$ & 7.98 & 1.74 & 5.1 & 0.81 \\
\hline U-109 & 23.4 & 0.302 & $56^{(\mathrm{a})}$ & 20 & 0.26 & 1.2 & 0.42 \\
\hline U-109 & 23.2 & 0.392 & $61.1^{\text {(a) }}$ & 15.1 & & 1.5 & 0.38 \\
\hline (a) Nitrogen purged. & & & & & \\
\hline
\end{tabular}

\subsection{Waste Sample Gas Composition Derived from Laboratory Tests}

The rate and composition of waste gas generation has been measured in the laboratory for six tanks under different combinations of temperature and irradiation conditions. This composition measurement method is the only one that allows us to predict gas composition change with temperature and irradiation.

The laboratory gas generation tests involved subjecting tank waste core samples under helium cover gas to different temperatures and levels of radiation (supplied by a ${ }^{137} \mathrm{Cs}$ gamma source). Runs typically lasted several hundred hours. The stainless-steel reaction vessels were cornected to a stainless-steel gas manifold outside the hot cell. Gas samples were taken from the manifold several times during the run and analyzed by mass spectrometry at RPL to determine composition. Argon was measured to determine the correction for nitrogen that leaked in from air. Ammonia was usually detected in these samples but is not included here because a total $\mathrm{NH}_{3}$ generation rate could not be measured accurately with the gas manifold system. Table 2.8 is a summary of generation rates and concentrations from the experiments (King and Bryan 1999). 
Table 2.8. Concentrations and Generation Rates of Gases Measured from Waste Samples

\begin{tabular}{|c|c|c|c|c|c|c|c|c|}
\hline Tank & \multicolumn{3}{|c|}{$\mathrm{H}_{2}$} & \multicolumn{3}{c|}{$\mathrm{N}_{2} \mathrm{O}$} & \multicolumn{3}{c|}{$\mathrm{N}_{2}$} & \multicolumn{3}{c|}{$\mathrm{CH}_{4}$} \\
\hline & mol/day $^{(\text {a) }}$ & $\%$ of total & mol/day $^{(\text {a) }}$ & $\%$ of total & mol/day & \% of total & mol/day $^{(a)}$ & $\%$ of total \\
\hline A-101 & 1.13 & 45.0 & 0.73 & 29.1 & 0.59 & 23.5 & 0.06 & 2.4 \\
\hline AW-101 & 11.6 & 81.2 & 1.6 & 11.2 & 1.0 & 7.0 & 0.09 & 0.6 \\
\hline S-102 & 1.0 & 61.8 & 0.4 & 24.7 & 0.2 & 12.4 & 0.019 & 1.2 \\
\hline S-106 & 0.19 & 39.8 & 0.2 & 41.9 & 0.08 & 16.8 & 0.007 & 1.5 \\
\hline SY-103 & 10.7 & 78.2 & 0.9 & 6.6 & 2.0 & 14.6 & 0.08 & 0.6 \\
\hline U-103 & 0.48 & 26.7 & 0.65 & 36.1 & 0.60 & 33.3 & 0.07 & 3.9 \\
\hline
\end{tabular}

(a) Based on tank waste mass, temperature, and dose rate.

\subsection{Summary of Gas Compositions}

As shown in Tables 2.3 and 2.7, the retained gas in the sampled tanks ranged from less than $20 \mathrm{~mol} \%$ to over $70 \mathrm{~mol} \% \mathrm{H}_{2}$. The results from laboratory gas generation tests also showed substantial variation in the $\mathrm{H}_{2}$ mole fraction. RGS samples indicated that the $\mathrm{H}_{2}$ mole fractions in liquid layers were lower than those in settled solids layers, even when the higher uncertainty associated with measuring smaller amounts of gas and proportionally larger contributions from air contamination in the liquid layers is taken into account.

The $\mathrm{N}_{2}$ and $\mathrm{N}_{2} \mathrm{O}$ mole fractions (Tables 2.4, 2.5, and 2.7) also varied considerably from tank to tank. The highest $\mathrm{N}_{2}$ values were often found in RGS samples from liquid layers with high uncertainties. In nonconvective and crust layers, the $\mathrm{N}_{2}$ mole fraction in most cases lay between one and three times the $\mathrm{N}_{2} \mathrm{O}$ mole fraction. However, five out of the six gas generation tests produced gas in which $\mathrm{N}_{2} \mathrm{O}$ exceeded $\mathrm{N}_{2}$.

The RGS-sampled tanks seemed to fall into two categories, one in which $\mathrm{N}_{2} \mathrm{O}$ was greater than 20 mol\% (AN-104, U-103, SX-106, S-102, U-109, and SY-101), and the other a relatively low $\mathrm{N}_{2} \mathrm{O}$ group. Of the drill string-sampled tanks, only BY-110 contained more than $20 \mathrm{~mol} \%$ $\mathrm{N}_{2} \mathrm{O}$, while some tanks that showed high $\mathrm{N}_{2} \mathrm{O}$ in RGS samples had low $\mathrm{N}_{2} \mathrm{O}$ in drill string samples. Waste from Tanks A-101, S-102, S-106, and U-103 generated gas with more than $20 \mathrm{~mol} \% \mathrm{~N}_{2} \mathrm{O}$ in laboratory tests.

Methane and non-methane hydrocarbons (NMHCs) made up the remaining low-solubility gas in the waste. RGS data indicate that $\mathrm{CH}_{4}$ made up less than $1 \mathrm{~mol} \%$ of the gas in 46 of the 75 samples taken. When non-methane hydrocarbons $\left(\mathrm{C}_{2} \mathrm{H}_{\mathrm{x}}, \mathrm{C}_{3} \mathrm{H}_{\mathrm{x}}\right.$, and others) are included, the sum of $\mathrm{CH}_{4}, \mathrm{C}_{2} \mathrm{H}_{\mathrm{x}}, \mathrm{C}_{3} \mathrm{H}_{\mathrm{x}}$, and other hydrocarbons equaled or exceeded $3 \mathrm{~mol} \%$ of the retained gas in 12 of the 75 RGS samples. These included five from AW-101 (with a maximum of $6 \mathrm{~mol} \%$ ), one from A-101 (5 mol\%), one from AN-105 (3 mol\%), one from AN-104 (3 mol\%), one from BY-109 (3 mol\%), two from SX-106 (the higher was $4 \mathrm{~mol} \%$ ), and one from AX-101 ( $3 \mathrm{~mol} \%$ ). Only one drill string sample, from BY-110, contained more than $1 \mathrm{~mol}^{2} \mathrm{CH}_{4}$. This same sample also contained a relatively high concentration, $2.9 \mathrm{~mol} \%$, of "other" gases. Of the six tanks whose waste was used in gas generation tests, only U-103 produced gas containing more than $3 \mathrm{~mol}_{\%} \mathrm{CH}_{4}$. 
The composition data obtained from headspace samples, RGS samples, drill string samples, and laboratory gas generation tests do not compare well. The reasons for the differences are not known. The $\mathrm{H}_{2} / \mathrm{N}_{2} \mathrm{O}$ ratio is used for comparison because it is the only composition property measured by all four methods. Part of the reason for differences may be that RGS methods showed in situ compositions, while headspace sample compositions often contain mixtures of gas from different layers (as may drill string samples). RGS samples show that gas composition can vary substantially from layer to layer.

Table 2.9 presents comparisons of the $\mathrm{H}_{2} / \mathrm{N}_{2} \mathrm{O}$ ratios in gas from RGS, drill string samples, SHMS, vapor grab samples, and laboratory gas generation tests on actual Hanford waste. Table 2.10 presents comparisons of the $\mathrm{H}_{2} / \mathrm{N}_{2}$ ratios in gas from RGS, drill string samples, and gas generation tests. Certain specific features are evident from the data compiled in the tables.

Table 2.9. Comparison of $\mathrm{H}_{2} / \mathrm{N}_{2} \mathrm{O}$ Ratios from RGS, Drill String Samples, SHMS, Vapor Grab Samples and Laboratory Gas Generation Tests

\begin{tabular}{|c|c|c|c|c|c|}
\hline Tank & $\begin{array}{l}\text { RGS } \mathrm{H}_{2} / \mathrm{N}_{2} \mathrm{O} \\
\text { (Tables } 2.3,2.5 \text { ) }\end{array}$ & $\begin{array}{l}\text { Drill String } \\
\mathrm{H}_{2} / \mathrm{N}_{2} \mathrm{O} \\
(\text { Table 2.7) }\end{array}$ & $\begin{array}{c}\text { Average } \\
\text { SHMS } \\
\mathrm{H}_{2} / \mathrm{N}_{2} \mathrm{O} \\
\text { (Table 2.1) }\end{array}$ & $\begin{array}{l}\text { Average of other } \\
\text { Headspace } \\
\text { Samples } \mathrm{H}_{2} / \mathrm{N}_{2} \mathrm{O} \\
\text { (Table 2.2) } \\
\end{array}$ & $\begin{array}{l}\text { Gas Generation } \\
\text { Test } \mathrm{H}_{2} / \mathrm{N}_{2} \mathrm{O} \\
\text { (Table 2.8) }\end{array}$ \\
\hline A-101 & $\begin{array}{l}\text { Convective: } 0.9 \pm 0.4-2.5 \pm 1.2 \\
\text { Nonconvective: } 12 \pm 1.8-13 \pm 1.7\end{array}$ & & 4.8 & 3.5 & 1.5 \\
\hline AN-103 & $\begin{array}{l}\text { Crust: } 9.0 \pm 1.3-10 \pm 1.4 \\
\text { Convective: } 2.3 \pm 2.1-7.3 \pm 6.6 \\
\text { Nonconvective: } 15 \pm 2.8-17 \pm 3.2 \\
\end{array}$ & 9.2 & 11 & & \\
\hline AN-104 & $\begin{array}{l}\text { Convective: } 1.6 \pm 1.2-5.0 \pm 4.1 \\
\text { Nonconvective: } 2.0 \pm 0.4-2.4 \pm 0.5 \\
\end{array}$ & 3.0 & 6.2 & & \\
\hline AN-105 & $\begin{array}{l}\text { Convective: } 1.9 \pm 1.3-5.4 \pm 3.9 \\
\text { Nonconvective: } 3.9 \pm 0.5-5.2 \pm 0.7\end{array}$ & & 5.3 & & \\
\hline AW-101 & $\begin{array}{l}\text { Convective: } 11 \pm 5.7-31 \pm 16 \\
\text { Nonconvective: } 4.3 \pm 0.6-6.5 \pm 1.0\end{array}$ & 12.5 & 43 & & 7.2 \\
\hline $\mathrm{AX}-101$ & Nonconvective: $5.5 \pm 0.7-5.8 \pm 0.8$ & & 9.6 & $>8.2$ & \\
\hline BY-109 & Nonconvective: $2.8 \pm 0.5-3.0 \pm 0.5$ & 3.4 & 10 & & \\
\hline S-102 & Nonconvective: $1.0 \pm 0.1-1.1 \pm 0.1$ & $1.7,12.3$ & 1.3 & 1.1 & 2.5 \\
\hline S-106 & Nonconvective: $5.7 \pm 0.7-7.1 \pm 1.0$ & $4.0,6.3$ & $>2$ & & 0.95 \\
\hline S-111 & $\begin{array}{l}\text { Convective: } 2.9 \pm 3.3-6.8 \pm 5.8 \\
\text { Nonconvective: } 6.0 \pm 1.3-6.8 \pm 5.8\end{array}$ & & 7.3 & 8.1 & \\
\hline SX-106 & $\begin{array}{l}\text { Convective: } 1.4 \pm 0.5-6.4 \pm 2.4 \\
\text { Nonconvective: } 2.1 \pm 0.3-2.2 \pm 0.3 \\
\end{array}$ & 2.5 & 3.0 & $<7$ & \\
\hline SY-101 & $\begin{array}{l}\text { Crust: } 1.8 \pm 0.3 \\
\text { Mixed slurry: } 1.1 \pm 0.5-1.9 \pm 0.8\end{array}$ & & 0.9 & & \\
\hline U-103 & Nonconvective: $0.6 \pm 0.05$ & & 0.7 & 0.6 & 0.74 \\
\hline U-109 & Nonconvective: $0.9 \pm 0.2-1.0 \pm 0.2$ & $5.1,1.2,1.5$ & 0.8 & 0.9 & \\
\hline
\end{tabular}


Table 2.10. Comparison of $\mathrm{H}_{2} / \mathrm{N}_{2}$ Ratios from RGS, Drill String Samples, SHMS, Vapor Grab Samples and Laboratory Gas Generation Tests

\begin{tabular}{|c|c|c|c|}
\hline Tank & $\begin{array}{c}\text { RGS } \mathrm{H}_{2} / \mathrm{N}_{2} \\
\text { (Tables } 2.3,2.4 \text { ) }\end{array}$ & $\begin{array}{c}\text { Drill string } \\
\mathrm{H}_{2} / \mathrm{N}_{2} \\
\text { (Table 2.7) }\end{array}$ & $\begin{array}{c}\text { Gas Generation } \\
\text { Test } \mathrm{H}_{2} / \mathrm{N}_{2} \\
\text { (Table 2.8) }\end{array}$ \\
\hline A-101 & $\begin{array}{l}\text { Convective: } 0.23 \pm 0.11-0.21 \pm 0.10 \\
\text { Nonconvective: } 3.7 \pm 1.0-3.8 \pm 1.0\end{array}$ & & 1.9 \\
\hline AN-103 & $\begin{array}{l}\text { Crust: } 2.1 \pm 0.3-2.2 \pm 0.3 \\
\text { Convective: } 0.3 \pm 0.3 \\
\text { Nonconvective: } 1.8 \pm 0.3-1.9 \pm 0.3\end{array}$ & 1.0 & \\
\hline AN-104 & $\begin{array}{l}\text { Convective: } 0.44 \pm 0.44 \\
\text { Nonconvective: } 1.6 \pm 0.4-1.5 \pm 0.3\end{array}$ & 0.62 & \\
\hline AN-105 & $\begin{array}{l}\text { Convective: } 0.44 \pm 0.38-0.39 \pm 0.34 \\
\text { Nonconvective: } 2.5 \pm 0.5-2.6 \pm 0.5\end{array}$ & & \\
\hline AW-101 & $\begin{array}{l}\text { Convective: } 0.39 \pm 0.23-0.36 \pm 0.22 \\
\text { Nonconvective: } 0.58 \pm 0.09\end{array}$ & 0.35 & 12 \\
\hline AX-101 & Nonconvective: $3.8 \pm 0.7-3.6 \pm 0.6$ & & \\
\hline BY-109 & Nonconvective: $1.8 \pm 0.4$ & 0.57 & \\
\hline S-102 & Nonconvective: $1.0 \pm 0.2$ & $0.44,0.61^{(a)}$ & 5.0 \\
\hline S-106 & Nonconvective: $2.5 \pm 0.4$ & $0.87,2.8$ & 2.4 \\
\hline S-111 & $\begin{array}{l}\text { Convective: } 0.07 \pm 0.08 \\
\text { Nonconvective: } 3.1 \pm 1.0\end{array}$ & & \\
\hline SX-106 & $\begin{array}{l}\text { Convective: } 0.34 \pm 0.14-0.24 \pm 0.10 \\
\text { Nonconvective: } 2.6 \pm 0.6-2.5 \pm 0.5 \\
\end{array}$ & 0.02 & \\
\hline SY-101 & $\begin{array}{l}\text { Crust: } 1.3 \pm 0.3 \\
\text { Mixed slurry: } 0.65 \pm 0.30\end{array}$ & & \\
\hline U-103 & Nonconvective: $0.6 \pm 0.06$ & & 0.80 \\
\hline U-109 & Nonconvective: $0.54 \pm 0.11$ & $\begin{array}{c}0.81,0.42 \\
0.38^{(\mathrm{a})}\end{array}$ & \\
\hline
\end{tabular}

- In some cases (AW-101, A-101, and AN-103) the $\mathrm{H}_{2} / \mathrm{N}_{2} \mathrm{O}$ ratios measured by RGS are substantially different for the convective and nonconvective layers. The direction of the difference is not consistent.

- In almost all cases (S-111 and SY-101 are exceptions), the RGS-measured $\mathrm{H}_{2} / \mathrm{N}_{2}$ ratio in the gas retained in the convective layer is between 0.2 and 0.45 .

- The $\mathrm{H}_{2} / \mathrm{N}_{2} \mathrm{O}$ and $\mathrm{H}_{2} / \mathrm{N}_{2}$ ratios of laboratory-generated gases do not match consistently those in gases measured in the waste or in the headspace. The direction of the difference is not consistent.

- The overall composition $\left(\mathrm{H}_{2} / \mathrm{N}_{2} \mathrm{O} / \mathrm{N}_{2}\right)$ of retained gas cannot be determined reliably from drill string samples because the $\mathrm{H}_{2} / \mathrm{N}_{2}$ ratio cannot be measured meaningfully in high-air samples and the $\mathrm{H}_{2} / \mathrm{N}_{2} \mathrm{O}$ ratio does not correlate with values obtained by other methods. 
RGS composition data, where available, are preferred to represent in situ gas composition because the measurements were made as nearly in situ as possible and contain all the constituents that affect flammability (Barker et al. 1999). However, ammonia released by evaporation must be added to RGS compositions of retained gas to represent the total release composition. Drill string and headspace data lack $\mathrm{N}_{2}$ measurements, which, in most retained gas, made up 20 to $50 \mathrm{~mol} \%$ of the gas. It follows that $\mathrm{N}_{2} \mathrm{O}$ and $\mathrm{H}_{2}$ together usually made up 50 to 80 $\mathrm{mol} \%$ of the gas, so the absence of $\mathrm{N}_{2}$ data introduces about $25 \%$ uncertainty into estimates of the $\mathrm{H}_{2}$ flammability contribution in the headspace after a large release. A larger uncertainty comes from the fact that the $\mathrm{H}_{2} / \mathrm{N}_{2} \mathrm{O}$ ratios from headspace and drill string measurements often were within about $50 \%$ of the RGS values but could as easily differ by more than a factor of 2 . Drill string $\mathrm{H}_{2} / \mathrm{N}_{2} \mathrm{O}$ ratios were usually closer to RGS values than the headspace measurements. 


\subsection{Flammability Limits}

The principal flammable products of Hanford waste gas generation reactions are $\mathrm{H}_{2}, \mathrm{~N}_{2} \mathrm{O}$, and $\mathrm{NH}_{3} . \mathrm{CH}_{4}$ and other hydrocarbons are present to a much lesser extent. These substances have been observed in many laboratory studies with simulants and in laboratory studies with actual waste samples (Ashby et al. 1992, 1993, 1994; Barefield et al. 1995, 1996; Bryan and Pederson 1993, 1994, 1995; Camaioni et al. 1997; Delegard 1980; Johnson 1997; King et al. 1997; Meisel et al. 1991a, 1991b, 1992,1993; Person 1996; Pederson and Bryan 1996). These same products are found in the headspace of actual waste tanks and in gas samples obtained using the RGS (Johnson 1997; Mahoney et al. 1999). This section summarizes experimental work investigating the flammability limits of these gases in the presence of air and $\mathrm{N}_{2} \mathrm{O}$, and applies the experimental results to assessing the flammability of the gases retained in selected tanks where gas compositions have been measured.

The flammability limits of a combustible mixture are those limiting compositions that will just support flame propagation when stimulated by an external ignition source. Although there is no widely accepted theoretical method for predicting flammability limits, there are a number of empirical rules and simple models, the results of which are summarized in Lewis and Von Elbe (1961) and updated by Hertzberg (1976). The fuel type, mixture properties, and mass diffusion of the deficient reactant are all factors in defining the limiting composition (Abbud-Madrid and Ronney 1990).

The primary reason for the existence of the flammability limit is heat loss (thermal radiation and conduction) from the hot products to the cooler surroundings (Spalding 1957). When the rate of heat loss exceeds the rate of heat generated by the chemical reactions, a flame cannot be supported. The composition at which a balance exists between heat loss and generation determines the flammability limit. Thermal radiation from infrared-active species $\mathrm{CO}_{2}$ and $\mathrm{H}_{2} \mathrm{O}$ is one mechanism of heat loss from propagating flames. Thermal conduction to cold container walls is also a major heat loss mechanism in standard flammability tests (Coward and Jones 1952). Flammability limit measurements are therefore dependent on vessel size and geometry.

Flame propagation in fuel-rich mixtures is limited by oxidant availability and in lean mixtures by fuel availability. Thus the conditions of flammability are characterized by the upper (rich) and lower (lean) flammability limits of fuel gas concentration. In considering the flammability hazard associated with tank wastes, we are concerned more with the LFL than with the upper flammability limit (UFL). The LFL is determined by the gas composition, energy and location of the ignition source, direction of flame propagation relative to gravity, and whether the gas is quiescent or being mixed. The gas composition effects include those associated with different oxidants $\left(\mathrm{O}_{2}\right.$ in air versus $\left.\mathrm{N}_{2} \mathrm{O}\right)$ and those associated with inert constituents.

In a quiescent atmosphere, the transition to flammability is abrupt and the LFL is higher (i.e., more fuel is required) for downward flame propagation than for upward propagation because of the buoyancy of the heated gases. Thus, the upward propagation limit (the minimum fuel concentration required for a flame to propagate upward) is lower than the downward propagation limit (the minimum fuel concentration required for a flame to propagate downward). In a turbulent, well-mixed atmosphere the transition to flammability is more gradual, with combustion pressures increasing linearly as the fuel concentration increases from the upward 
propagation limit. However, the flame propagation speed remains relatively low for concentrations above the upward propagation limit but below the downward propagation limit (Cashdollar et al. 1992). A very energetic ignition source has an effect similar to turbulence.

The flammability limits in air for both upward and downward propagation for $\mathrm{H}_{2}, \mathrm{CH}_{4}$, and $\mathrm{NH}_{3}$ are summarized in Table 3.1. ${ }^{\text {(a) }}$ The minimum amount of $\mathrm{N}_{2}$ needed to inert a fuel/air mixture is also given. The corresponding limits for $\mathrm{N}_{2} \mathrm{O}$ are given in Table 3.2. The tables were compiled from experiments in which high ignition energies between 5 and $10 \mathrm{~J}$ were used.

Table 3.1. Flammability Limits of Hydrogen, Ammonia, and Methane in Air

\begin{tabular}{|c|c|c|c|c|}
\hline \multirow{2}{*}{ Fuel } & \multicolumn{2}{|c|}{$\begin{array}{c}\text { Lower Flammability Limit } \\
\text { in Air (mol\%) }\end{array}$} & \multirow{2}{*}{$\begin{array}{c}\text { Upper } \\
\text { Flammability } \\
\text { Limit in Air } \\
(\mathrm{mol} \%)\end{array}$} & \multirow{2}{*}{$\begin{array}{c}\text { Minimum } \\
\text { Nitrogen to } \\
\text { Inert }(\mathrm{mol} \%)\end{array}$} \\
\hline & $\begin{array}{l}\text { Upward } \\
\text { Propagation }\end{array}$ & $\begin{array}{c}\text { Downward } \\
\text { Propagation }\end{array}$ & & \\
\hline Hydrogen & 4 & 8 & 75 & 70 \\
\hline Methane & 5 & 5 & 15 & 37 \\
\hline Ammonia & 15 & 18 & 28 & 17 \\
\hline
\end{tabular}

Table 3.2. Flammability Limits of Hydrogen, Ammonia, and Methane in Nitrous Oxide

\begin{tabular}{|c|c|c|c|c|}
\hline \multirow{2}{*}{ Fuel } & \multicolumn{2}{|c|}{$\begin{array}{l}\text { Lower Flammability Limit } \\
\text { in } \mathrm{N}_{2} \mathrm{O}(\mathrm{mol} \%)\end{array}$} & \multirow{2}{*}{$\begin{array}{c}\text { Upper } \\
\text { Flammability } \\
\text { Limit in } \mathrm{N}_{2} \mathrm{O} \\
(\mathrm{mol} \%)\end{array}$} & \multirow{2}{*}{$\begin{array}{l}\text { Minimum } \\
\text { Nitrogen to } \\
\text { Inert (mol\%) }\end{array}$} \\
\hline & $\begin{array}{l}\text { Upward } \\
\text { Propagation }\end{array}$ & $\begin{array}{l}\text { Downward } \\
\text { Propagation }\end{array}$ & & \\
\hline Hydrogen & 3 & 6 & 84 & $\sim 60$ \\
\hline Methane & 2.8 & 5 & 50 & 70 \\
\hline Ammonia & 2.6 & 6.8 & 71 & 60 \\
\hline
\end{tabular}

\subsection{Flammability of Hydrogen in Air and Nitrous Oxide}

Hydrogen is the most abundant flammable gas in Hanford tanks. Methane and $\mathrm{NH}_{3}$ also contribute to mixture flammability, though to a much smaller extent in the typical waste tank scenario. Other organic gases may also be present at very small concentrations but have no practical effect on flammability (Hedengren et al. 1997).

The limits for flammability for $\mathrm{H}_{2}-\mathrm{N}_{2} \mathrm{O}$-air mixtures are shown in Figure 3.1 (Coward and

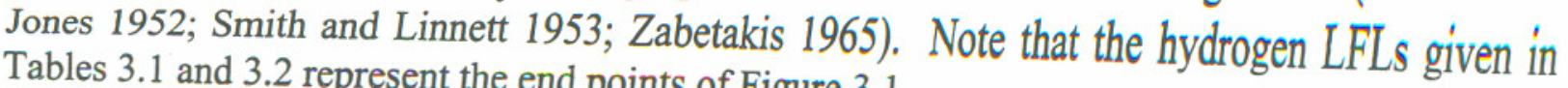
Tables 3.1 and 3.2 represent the end points of Figure 3.1.

(a) Pfahl U and JE Shepherd. April 29, 1997. Flammability and Flame Propagation in $\mathrm{H}_{2}-\mathrm{N}_{2} \mathrm{O}-\mathrm{CH}_{4-}$ $\mathrm{NH}_{3}-\mathrm{O}_{2}-\mathrm{N}_{2}$ Mixtures. Report FM97-4, Explosion Dynamics Laboratory, Pasadena, California. 


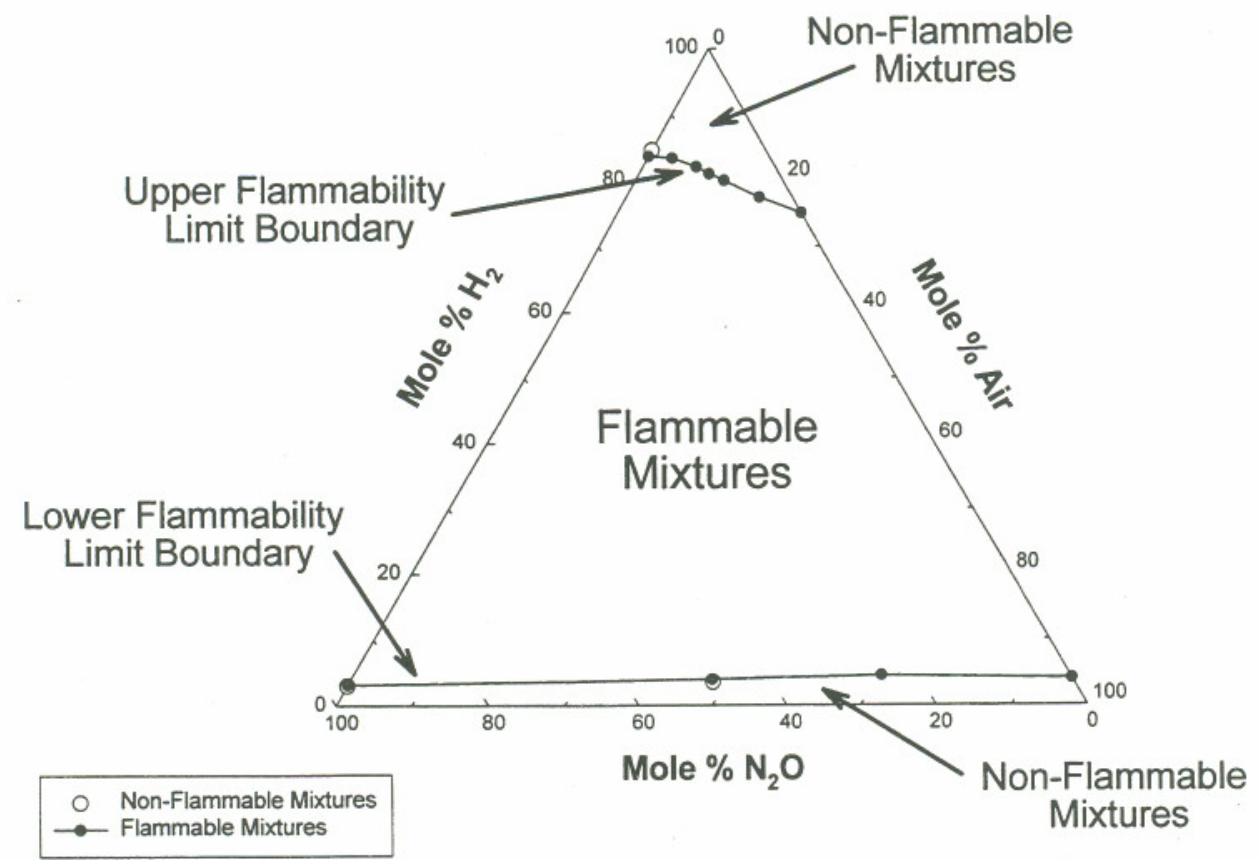

Figure 3.1. Limits of Flammability of the System $\mathrm{H}_{2}-\mathrm{N}_{2} \mathrm{O}-$ Air at $28^{\circ} \mathrm{C}$ and $1 \mathrm{~atm}$ (Coward and Jones 1952; Smith and Linnett 1953; Zabetakis 1965)

The LFLs of $\mathrm{H}_{2}$ in air- $\mathrm{N}_{2} \mathrm{O}$ mixtures were recently investigated in detail by Breshears et al. (1997), Cashdollar et al. (1992), and others. ${ }^{\text {(a) }}$ Their findings were in agreement with the earlier work. These studies all confirm that the LFL for $\mathrm{H}_{2}$ ( 8 to $9 \mathrm{~mol} \% \mathrm{H}_{2}$, quiescent mixtures) does not change significantly when air is replaced by $\mathrm{N}_{2} \mathrm{O}$ as the oxidant (Figure 3.1), even though the reaction of $\mathrm{H}_{2}$ with $\mathrm{N}_{2} \mathrm{O}$ (Eq. 3.1) is significantly more exothermic than with $\mathrm{O}_{2}$ (Eq. 3.2).

$$
\begin{array}{ll}
\mathrm{H}_{2}+1 / 2 \mathrm{O}_{2} \rightarrow \mathrm{H}_{2} \mathrm{O} & \Delta \mathrm{H}_{298}=-57.65 \mathrm{kcal} / \mathrm{mol} \\
\mathrm{H}_{2}+\mathrm{N}_{2} \mathrm{O} \rightarrow \mathrm{H}_{2} \mathrm{O}+\mathrm{N}_{2} & \Delta \mathrm{H}_{298}=-76.99 \mathrm{kcal} / \mathrm{mol}
\end{array}
$$

Analysis by Breshears et al. (1997) shows these results to be consistent with a chemical kinetic model in which (at atmospheric pressures and temperatures below about $1000 \mathrm{~K}$ ) the dominant channel for reaction of hydrogen atoms is formation of $\mathrm{HO}_{2}$, the hydroperoxy radical:

$$
\mathrm{H}+\mathrm{O}_{2}+\mathrm{M} \rightarrow \mathrm{HO}_{2}+\mathrm{M}
$$

(a) Ross MC and JE Shepherd. July 9, 1996. Lean Combustion Characteristics of Hydrogen-Nitrous Oxide-Ammonia Mixtures in Air. Part I. Report FM96-4, Explosion Dynamics Laboratory, Pasadena, California. 
Several subsequent reactions may occur, including the sequence

$$
\begin{gathered}
\mathrm{H}+\mathrm{HO}_{2} \rightarrow 2 \mathrm{OH} \\
\mathrm{OH}+\mathrm{H}_{2} \rightarrow \mathrm{H}_{2} \mathrm{O}+\mathrm{H}
\end{gathered}
$$

Summation of Eq. (3.3), (3.4) and twice (3.5) yields twice (3.1). Reactions (3.3) through (3.5) compose a straight chain mechanism in which the net atom and radical concentration is conserved. However, addition reaction channels such as

$$
\mathrm{H}+\mathrm{HO}_{2} \rightarrow \mathrm{H}_{2}+\mathrm{O}_{2}
$$

result in a net loss of atoms and radicals such that the flame propagation solely by a straight chain mechanism is considered to be highly improbable.

At temperatures above about $1000 \mathrm{~K}$, the chain branching reaction

$$
\mathrm{H}+\mathrm{O}_{2} \rightarrow \mathrm{OH}+\mathrm{O}
$$

becomes the dominant hydrogen atom reaction path, followed by reaction (3.5) and a second chain branching reaction:

$$
\mathrm{O}+\mathrm{H}_{2} \rightarrow \mathrm{OH}+\mathrm{H}
$$

Summing Eq. (3.7), (3.8), and (3.5) yields

$$
2 \mathrm{H}_{2}+\mathrm{O}_{2} \rightarrow \mathrm{H}_{2} \mathrm{O}+\mathrm{H}+\mathrm{OH}
$$

Now, two additional atoms and radicals are produced for each $\mathrm{O}_{2}$ molecule consumed, and the net chain branching reaction can overcome the normal loss mechanisms.

The LFL of 8 to $9 \mathrm{~mol} \% \mathrm{H}_{2}$ (quiescent) for $\mathrm{H}_{2}$-air mixtures corresponds very closely to the amount of $\mathrm{H}_{2}$ combustion required to reach a temperature of about $1000 \mathrm{~K}$, i.e., to a temperature above which the chain branching reaction dominates. Further, the dominant channel for reaction of $\mathrm{N}_{2} \mathrm{O}$ in this system is

$$
\mathrm{H}+\mathrm{N}_{2} \mathrm{O} \rightarrow \mathrm{N}_{2}+\mathrm{OH}
$$

which, summed with reaction (3.5), yields (3.2).

Rate constants for reactions (3.7) and (3.10) are very nearly equal at temperatures above about $700 \mathrm{~K}$, with the result that $\mathrm{N}_{2} \mathrm{O}$ begins to react with $\mathrm{H}_{2}$ only for initial $\mathrm{H}_{2}$ mole fractions that are already above the LFL for $\mathrm{H}_{2}$-air mixtures. Moreover, a very energetic ignition source is 
required to bring the temperature to the point where the reaction can occur. Below that temperature, $\mathrm{N}_{2} \mathrm{O}$ acts as a diluent. An $\mathrm{H}_{2}$ mole fraction of 0.10 or more is required to fully react the $\mathrm{N}_{2} \mathrm{O}$. (a)

No information was found concerning the LFL of $\mathrm{H}_{2}$ in $\mathrm{N}_{2} \mathrm{O}$ as a function of the ignition energy. It is known that, at very high ignition energies (i.e., on the order of $5000 \mathrm{~J}$ ), $\mathrm{N}_{2} \mathrm{O}$ decomposes even in the absence of fuel.

\subsection{Flammability of Ammonia in Air and Nitrous Oxide}

Ammonia is a pervasive constituent of wastes stored at Hanford (Mahoney et al. 1999). Ammonia is difficult to ignite and was not even considered flammable as recently as 1951 (Buckley and Husa 1962). Ammonia has a very low flame speed and requires relatively high concentrations to support combustion (its LFL in air is about $15 \mathrm{~mol} \%$ ) and relatively highenergy ignition sources to initiate combustion ( 8 to $680 \mathrm{~mJ}$ compared with about $0.01 \mathrm{~mJ}$ for $\left.\mathrm{CH}_{4}\right)^{\left({ }^{(a)}\right.}$ These minimum ignition energies pertain to fuel-rich conditions; in general, higher ignition energies are required near the LFL.

Because $\mathrm{NH}_{3}$ is used extensively as a refrigerant, the combustion of $\mathrm{NH}_{3}$-air mixtures has been well studied (Fenton et al. 1995). Accepted limits for $\mathrm{NH}_{3}$-air flammabilities are scattered around $15 \mathrm{~mol} \%$ for upward and $18 \mathrm{~mol} \%$ for downward propagation (Ronney 1987, Table 3.2). Unlike $\mathrm{H}_{2}$, the UFL of $\mathrm{NH}_{3}$ is reduced when $\mathrm{N}_{2} \mathrm{O}$ is substituted for air as the oxidant. The presence of $8 \mathrm{~mol} \% \mathrm{~N}_{2} \mathrm{O}$ (in air) decreased the LFL of $\mathrm{NH}_{3}$ from $18 \mathrm{~mol} \%$ to $15 \mathrm{~mol} \%{ }^{\text {(b) }}$ While the mechanism for the reaction of $\mathrm{NH}_{3}$ with $\mathrm{N}_{2} \mathrm{O}$ was not captured by a simple kinetic model (Breshears et al. 1997), factors contributing to the lowering of the $\mathrm{LFL}$ of $\mathrm{NH}_{3}$ by addition of $\mathrm{N}_{2} \mathrm{O}$ were investigated and discussed. ${ }^{(b)}$

Apparently, the differences in the effect of $\mathrm{N}_{2} \mathrm{O}$ on $\mathrm{H}_{2}$ and $\mathrm{NH}_{3}$ mixtures are due to several factors. Temperature is the main factor. ${ }^{\text {(a) }}$ Lean $\mathrm{H}_{2}$-air flames have a very low product temperature $(<1100 \mathrm{~K})$ and $\mathrm{N}_{2} \mathrm{O}$ decomposes very slowly under these conditions. In contrast, the product temperature of lean $\mathrm{NH}_{3}$-air flames is much higher, and at the higher temperature $\mathrm{N}_{2} \mathrm{O}$ decomposes readily. In mixtures where the only oxidant is $\mathrm{N}_{2} \mathrm{O}$ (no air), the decomposition of $\mathrm{N}_{2} \mathrm{O}$ is stoichiometrically complete. In addition, there appear to be reactive intermediates characteristic of nitrogen chemistry that play a role in $\mathrm{NH}_{3}-\mathrm{N}_{2} \mathrm{O}$ combustion and are not factors for $\mathrm{H}_{2}-\mathrm{N}_{2} \mathrm{O}$ combustion.

The differences in radicals and reactive intermediates are one explanation offered for the observation that the $\mathrm{NH}_{3}-\mathrm{N}_{2} \mathrm{O}$ LFL is lower than the $\mathrm{NH}_{3}$-air LFL. At high temperatures $(>1300 \mathrm{~K})$, the primary reaction responsible for the decomposition of $\mathrm{NH}_{3}$ is

$$
\mathrm{OH}+\mathrm{NH}_{3} \rightarrow \mathrm{H}_{2} \mathrm{O}+\mathrm{NH}_{2}
$$

(a) Pfahl U and JE Shepherd. April 29, 1997. Flammability and Flame Propagation in $\mathrm{H}_{2}-\mathrm{N}_{2} \mathrm{O}-\mathrm{CH}_{4}-$ $\mathrm{NH}_{3}-\mathrm{O}_{2}-\mathrm{N}_{2}$ Mixtures. Report FM97-4, Explosion Dynamics Laboratory, Pasadena, California.

(b) Ross MC and JE Shepherd, Lean Combustion Characteristics of Hydrogen-Nitrous Oxide-Ammonia Mixtures in Air. Part I. Report FM96-4, Explosion Dynamics Laboratory, Pasadena, California. 
In mixtures of $\mathrm{H}_{2}$ and $\mathrm{NH}_{3}$, this reaction can proceed simultaneously with reaction (3.5) without interference. ${ }^{(a)}$ It is known that at lower temperatures $(<1100 \mathrm{~K})$ the chain branching mechanism is not important, but reaction (3.3) is the primary path for hydrogen atom reaction. The primary mechanism for $\mathrm{NH}_{3}$ consumption in lower temperature flames appears to be

$$
\begin{gathered}
\mathrm{NH}_{3}+\mathrm{OH} \rightarrow \mathrm{NH}_{2}+\mathrm{H}_{2} \mathrm{O} \\
\mathrm{NH}_{2}+\mathrm{OH} \rightarrow \mathrm{NH}+\mathrm{H}_{2} \mathrm{O} \\
\mathrm{NH}+\mathrm{NO} \rightarrow \mathrm{N}_{2} \mathrm{O}+\mathrm{H} \text { or } \mathrm{N}_{2}+\mathrm{OH}
\end{gathered}
$$

The decrease in the $\mathrm{LFL}$ of $\mathrm{NH}_{3}$ from $15 \mathrm{~mol} \%$ in air to an estimated $2.6 \mathrm{~mol} \%$ in $\mathrm{N}_{2} \mathrm{O}$ may be due to the decomposition of $\mathrm{N}_{2} \mathrm{O}$ in the high-temperature $\mathrm{NH}_{3}$ flames following the reactions

$$
\mathrm{N}_{2} \mathrm{O}+\mathrm{M} \rightarrow \mathrm{N}_{2}+\mathrm{O}+\mathrm{M}
$$

and

$$
\mathrm{H}+\mathrm{N}_{2} \mathrm{O} \rightarrow \mathrm{N}_{2}+\mathrm{OH}
$$

The flammability limits of $\mathrm{NH}_{3}$ in $\mathrm{N}_{2} \mathrm{O}$ are strong functions of the ignition energy. ${ }^{(b)}$ At an ignition energy of $0.04 \mathrm{~J}$, the LFL is $11.5 \mathrm{~mol} \% \mathrm{NH}_{3}$ rather than the $5.2 \mathrm{~mol} \%$ found for ignition energies of $1 \mathrm{~J}$ or more. The UFL decreases from $67.5 \mathrm{~mol} \%$ at $8 \mathrm{~J}$ ignition energy to $54 \mathrm{~mol} \%$ at $0.04 \mathrm{~J}$ ignition energy. Both the LFL and the UFL are independent of the ignition energy for ignition energies between $1 \mathrm{~J}$ and $10 \mathrm{~J}$ and may remain independent up to $100 \mathrm{~J}$ or more. For a mixture of $40 \% \mathrm{NH}_{3}-60 \% \mathrm{~N}_{2} \mathrm{O}$ (well above the LFL), a minimum ignition energy of $0.07 \mathrm{~mJ}$ was measured (Calcote et al. 1952); it is typical for minimum ignition energies to be found in fuelrich mixtures.

\subsection{Effect of Water Vapor on Ammonia-Air LFL}

Water vapor raises the $\mathrm{LFL}$ of $\mathrm{NH}_{3}$-air mixtures. If the water vapor mole fraction exceeds 8 to $11 \mathrm{~mol} \%$, the mixture is not flammable. For comparison, 17 to $19 \mathrm{~mol} \% \mathrm{~N}_{2}$ is required to inert a mixture whose other components are $\mathrm{NH}_{3}$ and air (at any $\mathrm{NH}_{3} /$ air ratio). The amount of water vapor necessary to prevent combustion increases from about $8 \mathrm{~mol} \%$ at $25^{\circ} \mathrm{C}$ to about 9 $\mathrm{mol} \%$ at $44^{\circ} \mathrm{C}$, and to about $11 \mathrm{~mol} \%$ at $80^{\circ} \mathrm{C}$ (Fenton et al. 1995). This is important because it is possible for the equilibrium headspace humidity to exceed this value at moderate temperatures.

The equilibrium water vapor fraction as a function of temperature and the flammability range for $\mathrm{NH}_{3}$-air-water vapor mixtures are shown on Figure 3.2. The equilibrium water vapor fraction above pure water (CRC 1990) exceeds the inerting value at $41^{\circ}$ to $48^{\circ} \mathrm{C}\left(106^{\circ}\right.$ to $\left.118^{\circ} \mathrm{F}\right)$. The

(a) Ross MC and JE Shepherd. July 9, 1996. Lean Combustion Characteristics of Hydrogen-Nitrous Oxide-Ammonia Mixtures in Air. Part I. Report FM96-4, Explosion Dynamics Laboratory, Pasadena, California.

(b) Pfahl U and JE Shepherd. April 29, 1997. Flammability and Flame Propagation in $\mathrm{H}_{2}-\mathrm{N}_{2} \mathrm{O}-\mathrm{CH}_{4-}$ $\mathrm{NH}_{3}-\mathrm{O}_{2}-\mathrm{N}_{2}$ Mixtures. Report FM97-4, Explosion Dynamics Laboratory, Pasadena, California. 


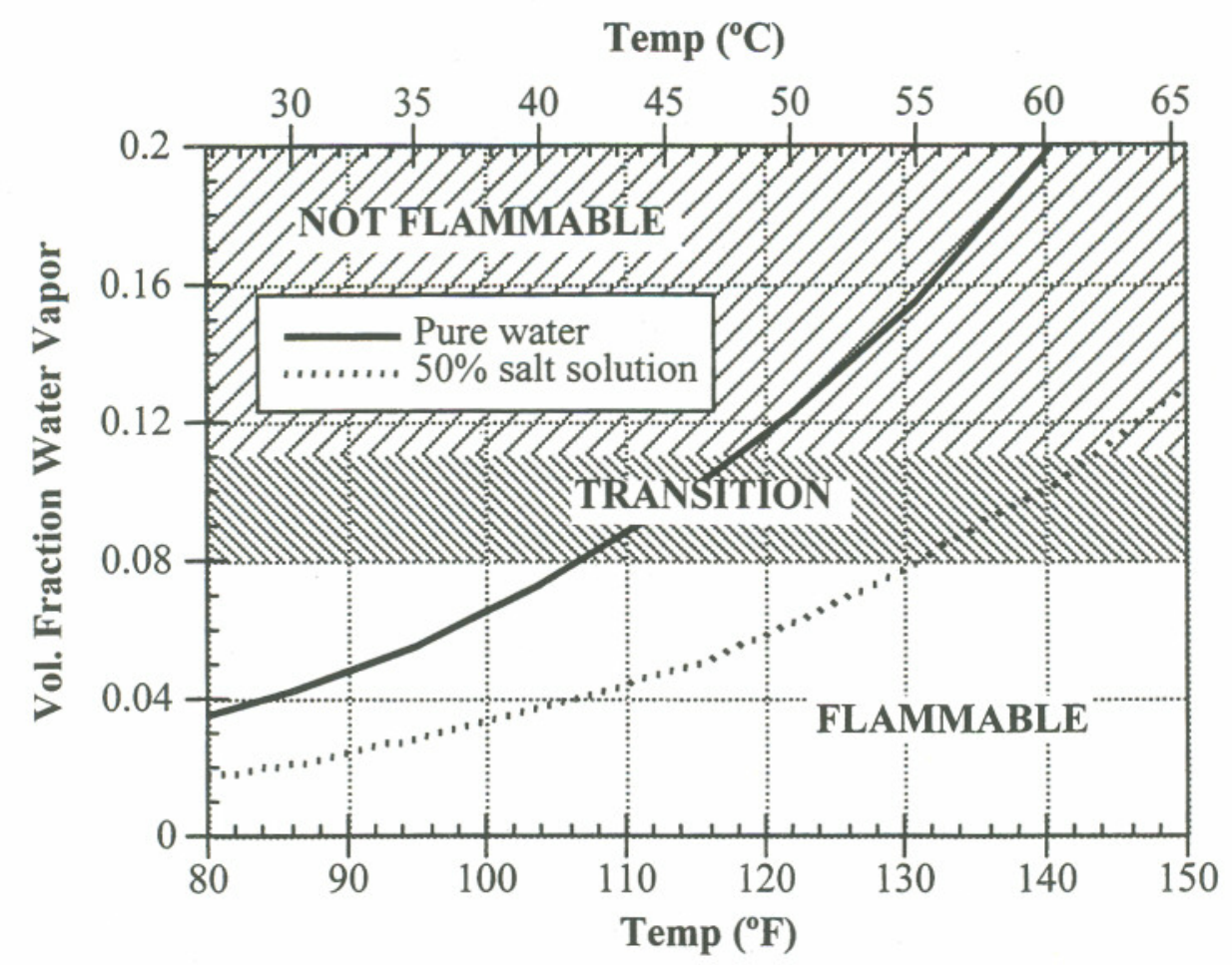

Figure 3.2. Equilibrium Water Vapor Fraction and Ammonia Flammability

vapor pressure over a salt solution containing $50 \mathrm{~mol} \%$ water (shown by the dashed line) is about half the vapor pressure over pure water based on a correlation developed by Mahoney and Trent (1995) from SY-101 chemical simulant data. This increases the temperature at which the mixture is inert to about $55^{\circ}$ to $61^{\circ} \mathrm{C}$. However, even if the temperature were sufficiently high, water vapor cannot confidently be claimed to prevent combustion because the mixture will contain $\mathrm{H}_{2}$, which is not effectively inerted by the relatively low mole fractions of water vapor present in tank headspaces. ${ }^{(a)}$

\subsection{Methane Flammability in Air and Nitrous Oxide}

The flammability of $\mathrm{CH}_{4}$ and other hydrocarbons in air has been studied extensively. The LFL for $\mathrm{CH}_{4}$ in air is $5.0 \mathrm{~mol} \%$ (Zabetakis 1965). The LFL for $\mathrm{CH}_{4}$ decreases to $4.8 \mathrm{~mol} \%$ in a mixture containing $10 \mathrm{~mol} \% \mathrm{~N}_{2} \mathrm{O}$ in air. The flammability limits of ternary mixtures of $\mathrm{CH}_{4}$ $\mathrm{N}_{2} \mathrm{O}-\mathrm{N}_{2}$ have been investigated. The LFL for $\mathrm{CH}_{4}$ in $\mathrm{N}_{2} \mathrm{O}$ is $2.8 \mathrm{~mol} \%$, ${ }^{(b)}$ and the UFL is 40 to $50 \mathrm{~mol} \%$. Adding $70 \mathrm{~mol} \% \mathrm{~N}_{2}$ will inert the mixture.

(a) Ross MC and JE Shepherd. July 9, 1996. Lean Combustion Characteristics of Hydrogen-Nitrous Oxide-Ammonia Mixtures in Air. Part I. Report FM96-4, Explosion Dynamics Laboratory, Pasadena, California.

(b) Pfahl U and JE Shepherd. April 29, 1997. Flammability and Flame Propagation in $\mathrm{H}_{2}-\mathrm{N}_{2} \mathrm{O}-\mathrm{CH}_{4}-$ $\mathrm{NH}_{3}-\mathrm{O}_{2}-\mathrm{N}_{2}$ Mixtures. Report FM97-4, Explosion Dynamics Laboratory, Pasadena, California. 
The characteristics of $\mathrm{CH}_{4}$-air- $\mathrm{N}_{2} \mathrm{O}$ mixtures differ from the results of $\mathrm{H}_{2}$-air- $\mathrm{N}_{2} \mathrm{O}$ mixtures described above. Methane-air- $\mathrm{N}_{2} \mathrm{O}$ mixtures behave similarly to $\mathrm{NH}_{3}-$ air- $\mathrm{N}_{2} \mathrm{O}$ mixtures in that the LFL for $\mathrm{CH}_{4}$ is decreased when $\mathrm{N}_{2} \mathrm{O}$ replaces air as the oxidant within the ternary system. The heats of combustion of $\mathrm{CH}_{4}$-air- $\mathrm{N}_{2} \mathrm{O}$ mixtures are higher than those of the $\mathrm{H}_{2}$-air- $\mathrm{N}_{2} \mathrm{O}$ system. Therefore, the flame temperature at the flammability limit will be much higher for $\mathrm{CH}_{4}$ than for $\mathrm{H}_{2}$. It follows that the rate of thermal decomposition of $\mathrm{N}_{2} \mathrm{O}$ following reaction (3-15) with an Arrhenius activation energy of approximately $60 \mathrm{kcal} / \mathrm{mol}$ (Breshears 1995) will be high at the $\mathrm{CH}_{4} \mathrm{LFL}$, and decomposition will always occur. ${ }^{\text {(a) }}$ This was also observed for the $\mathrm{NH}_{3}$ air- $\mathrm{N}_{2} \mathrm{O}$ system with significant $\mathrm{N}_{2} \mathrm{O}$ decomposition occurring near the lean limit of mixtures containing large fractions of $\mathrm{NH}_{3}$. ${ }^{(a)}$

Although $\mathrm{CH}_{4}$ and $\mathrm{N}_{2} \mathrm{O}$ burn readily, the amount of $\mathrm{CH}_{4}$ in tank wastes is small. Other hydrocarbons are not a flammability concern, even though their LFLs are even lower than $\mathrm{CH}_{4}$, because their concentrations are typically much lower even than those of $\mathrm{CH}_{4}$.

The LFL of $\mathrm{CH}_{4}$ in $\mathrm{N}_{2} \mathrm{O}$ is a strong function of the ignition energy. ${ }^{\text {(a) }}$ At an ignition energy of $0.04 \mathrm{~J}$, the $\mathrm{LFL}$ is $4.8 \mathrm{~mol}_{\%} \mathrm{CH}_{4}$, but it decreases to $2.8 \mathrm{~mol} \%$ for ignition energies of $1 \mathrm{~J}$ or more. The LFL is independent of the ignition energy for ignition energies between $1 \mathrm{~J}$ and $10 \mathrm{~J}$ and may remain independent up to $100 \mathrm{~J}$ or more.

\subsection{Flammability of Hydrogen, Methane, and Ammonia Mixtures in Air}

Experiments (Cashdollar et al. 1992) have shown that the LFL of a mixture of $\mathrm{H}_{2}, \mathrm{NH}_{3}$, and $\mathrm{CH}_{4}$ in an air- $\mathrm{N}_{2} \mathrm{O}$ atmosphere can be computed from the LFL of each fuel using LeChatelier's linear mixing law:

$$
\frac{1}{[\mathrm{MIX}]_{\mathrm{LFL}}}=\frac{\left[\mathrm{H}_{2}\right]_{\mathrm{MIX}}}{\left[\mathrm{H}_{2}\right]_{\mathrm{LFL}}}+\frac{\left[\mathrm{CH}_{4}\right]_{\mathrm{MIX}}}{\left[\mathrm{CH}_{4}\right]_{\mathrm{LFL}}}+\frac{\left[\mathrm{NH}_{3}\right]_{\mathrm{MIX}}}{\left[\mathrm{NH}_{3}\right]_{\mathrm{LFL}}}
$$

where $[\mathrm{MIX}]_{\mathrm{LFL}}=$ concentration of the gas mixture at the LFL in air

[gas $]_{\mathrm{MIX}}=$ concentration of the gas composing the fuel mixture

$[\text { gas }]_{\mathrm{LFL}}=$ concentration of the pure gas at the LFL in air.

The concentration of $\mathrm{H}_{2}$ is usually monitored to detect flammable conditions. The $\mathrm{H}_{2}$ concentration at which a mixture of $\mathrm{H}_{2}$ with other gases is flammable is given by

$$
\left[\mathrm{H}_{2}\right]_{\mathrm{MIX}, \mathrm{LFL}}=\mathrm{X}_{\mathrm{H}_{2}}[\mathrm{MIX}]_{\mathrm{LFL}}
$$

where $X_{\mathrm{H} 2}=$ mole fraction of $\mathrm{H}_{2}$. In a waste tank $23 \mathrm{~m}(75 \mathrm{ft})$ in diameter, the headspace would generally be expected to be turbulent, and the upward propagation flammability limit is appropriate for determining whether ignition is possible.

(a) Ross MC and JE Shepherd. July 9, 1996. Lean Combustion Characteristics of Hydrogen-Nitrous Oxide-Ammonia Mixtures in Air. Part I. Report FM96-4, Explosion Dynamics Laboratory, Pasadena, California. 
Table 3.3 lists the waste gas fractions required to reach the LFL for gas from the gasretaining layer(s) of the RGS-sampled tanks, calculated from Eq. (3.17) and based on the RGS compositions given in Section 2 for the low-gas solubility bound. The waste gas fraction is the mole fraction of waste gas in the mixture of air and waste gas. The fractions in Table 3.3 do not include the extra ammonia that could be released by evaporation and are not conservative for significant evaporative releases. Because of its higher LFL, ammonia has only $27 \%$ as much effect on flammability as hydrogen-it takes $3.75 \mathrm{~mol}^{2} \mathrm{NH}_{3}$ to have as much effect as $1 \mathrm{~mol} \%$ $\mathrm{H}_{2}$. The lower effectiveness of ammonia makes up, to some extent, for the greater uncertainty in its concentration (compared with hydrogen).

Table 3.3. Waste Gas Fractions at the LFL in Air/Gas Mixtures

\begin{tabular}{|c|c|c|c|}
\hline Source of Gas & $\begin{array}{c}\text { Composition } \\
(\mathrm{mol} \%)\end{array}$ & $\begin{array}{l}\text { Fraction }^{(\mathrm{a})} \text { of Gas in } \\
\text { Air/Gas Mixture to } \\
\text { Reach LFL (mol\%) }\end{array}$ & $\begin{array}{c}\text { Fraction }^{(\mathrm{a})} \text { of } \mathrm{H}_{2} \text { in } \\
\text { Mixture } \\
\text { at LFL }(\mathrm{mol} \%)\end{array}$ \\
\hline A-101 nonconvective & $\begin{array}{c}19 \% \mathrm{~N}_{2}, 70 \% \mathrm{H}_{2}, 4.8 \% \mathrm{NH}_{3}, \\
5.7 \% \mathrm{~N}_{2} \mathrm{O}, 0.7 \% \mathrm{CH}_{4}\end{array}$ & 5.6 & 3.9 \\
\hline AN-103 crust & $\begin{array}{c}29 \% \mathrm{~N}_{2}, 62 \% \mathrm{H}_{2}, 1.8 \% \mathrm{NH}_{3}, \\
6.9 \% \mathrm{~N}_{2} \mathrm{O}, 0.6 \% \mathrm{CH}_{4}\end{array}$ & 6.3 & 3.9 \\
\hline AN-103 nonconvective & $\begin{array}{c}33 \% \mathrm{~N}_{2}, 61 \% \mathrm{H}_{2}, 0.9 \% \mathrm{NH}_{3}, \\
4.2 \% \mathrm{~N}_{2} \mathrm{O}, 0.6 \% \mathrm{CH}_{4}\end{array}$ & 6.5 & 4.0 \\
\hline AN-104 nonconvective & $\begin{array}{c}29 \% \mathrm{~N}_{2}, 45 \% \mathrm{H}_{2}, 1.4 \% \mathrm{NH}_{3} \\
23 \% \mathrm{~N}_{2} \mathrm{O}, 0.9 \% \mathrm{CH}_{4}\end{array}$ & 8.6 & 3.9 \\
\hline AN-105 nonconvective & $\begin{array}{c}24 \% \mathrm{~N}_{2}, 59 \% \mathrm{H}_{2}, 0.6 \% \mathrm{NH}_{3}, \\
15 \% \mathrm{~N}_{2} \mathrm{O}, 0.7 \% \mathrm{CH}_{4}\end{array}$ & 6.7 & 3.9 \\
\hline AW-101 nonconvective & $\begin{array}{c}55 \% \mathrm{~N}_{2}, 32 \% \mathrm{H}_{2}, 0.9 \% \mathrm{NH}_{3} \\
7.5 \% \mathrm{~N}_{2} \mathrm{O}, 1.7 \% \mathrm{CH}_{4}\end{array}$ & 12 & 3.8 \\
\hline AX-101 nonconvective & $\begin{array}{c}16 \% \mathrm{~N}_{2}, 60 \% \mathrm{H}_{2}, 9.1 \% \mathrm{NH}_{3}, \\
11 \% \mathrm{~N}_{2} \mathrm{O}, 2.4 \% \mathrm{CH}_{4}\end{array}$ & 6.2 & 3.7 \\
\hline BY-109 nonconvective & $\begin{array}{c}28 \% \mathrm{~N}_{2}, 50 \% \mathrm{H}_{2}, 0.3 \% \mathrm{NH}_{3}, \\
18 \% \mathrm{~N}_{2} \mathrm{O}, 0.8 \% \mathrm{CH}_{4}\end{array}$ & 7.8 & 3.9 \\
\hline S-102 nonconvective & $\begin{array}{c}32 \% \mathrm{~N}_{2}, 33 \% \mathrm{H}_{2}, 1.0 \% \mathrm{NH}_{3} \\
33 \% \mathrm{~N}_{2} \mathrm{O}, 0.4 \% \mathrm{CH}_{4}\end{array}$ & 12 & 4.0 \\
\hline S-106 nonconvective & $\begin{array}{c}25 \% \mathrm{~N}_{2}, 63 \% \mathrm{H}_{2}, 0.4 \% \mathrm{NH}_{3}, \\
11 \% \mathrm{~N}_{2} \mathrm{O}, 0.3 \% \mathrm{CH}_{4}\end{array}$ & 6.3 & 4.0 \\
\hline S-111 nonconvective & $\begin{array}{c}21 \% \mathrm{~N}_{2}, 66 \% \mathrm{H}_{2}, 1.0 \% \mathrm{NH}_{3} \\
11 \% \mathrm{~N}_{2} \mathrm{O}, 0.5 \% \mathrm{CH}_{4}\end{array}$ & 6.0 & 4.0 \\
\hline SX-106 nonconvective & $\begin{array}{c}20 \% \mathrm{~N}_{2}, 51 \% \mathrm{H}_{2}, 4.4 \% \mathrm{NH}_{3}, \\
24 \% \mathrm{~N}_{2} \mathrm{O}, 0.6 \% \mathrm{CH}_{4}\end{array}$ & 7.5 & 3.8 \\
\hline SY-101 crust & $\begin{array}{c}27 \% \mathrm{~N}_{2}, 34 \% \mathrm{H}_{2}, 19 \% \mathrm{NH}_{3} \\
19 \% \mathrm{~N}_{2} \mathrm{O}, 0.6 \% \mathrm{CH}_{4}\end{array}$ & 10 & 3.4 \\
\hline SY-101 mixed slurry & $\begin{array}{c}40 \% \mathrm{~N}_{2}, 26 \% \mathrm{H}_{2}, 7.1 \% \mathrm{NH}_{3}, \\
24 \% \mathrm{~N}_{2} \mathrm{O}, 1.3 \% \mathrm{CH}_{4}\end{array}$ & 14 & 3.6 \\
\hline U-103 nonconvective & $\begin{array}{c}36 \% \mathrm{~N}_{2}, 23 \% \mathrm{H}_{2}, 0.6 \% \mathrm{NH}_{3}, \\
40 \% \mathrm{~N}_{2} \mathrm{O}, 0.4 \% \mathrm{CH}_{4}\end{array}$ & 16 & 3.7 \\
\hline U-109 nonconvective & $\begin{array}{c}46 \% \mathrm{~N}_{2}, 25 \% \mathrm{H}_{2}, 0.9 \% \mathrm{NH}_{3} \\
27 \% \mathrm{~N}_{2} \mathrm{O}, 0.7 \% \mathrm{CH}_{4}\end{array}$ & 15 & 3.8 \\
\hline
\end{tabular}


The effects of inerting by the $\mathrm{N}_{2}$ in the waste gas were not considered, giving somewhat conservative (underestimated) waste-gas fractions. However, little inerting effect is expected at the low fractions of waste gas that are required to reach the LFL.

\subsection{Self-Flammability of Hydrogen, Methane, Ammonia, and Nitrous Oxide Mixtures}

Given the right gas composition and an adequate ignition source, combustion could in theory occur in gas in the pores of a matrix. Thus the self-flammability of the waste gas alone, in the absence of air, must be considered. Under airless conditions, $\mathrm{N}_{2} \mathrm{O}$ serves as the sole oxidant, and $\mathrm{N}_{2}$ may in some cases inert the retained gas.

As the fraction of inert gas (in this case, $\mathrm{N}_{2}$ ) increases in a mixture, the LFL typically increases slightly and the UFL decreases steeply. At a fraction of the inert gas that is known as the inerting concentration, the UFL decreases to the point that it is equal to the LFL. When the inert gas increases above the inerting concentration, combustion cannot occur.

The LFL of $\mathrm{NH}_{3}$ in $\mathrm{N}_{2} \mathrm{O}$ increases almost linearly from $5.2 \mathrm{~mol} \%$ (with no $\mathrm{N}_{2}$ present) to $11.5 \mathrm{~mol} \%$ when the inerting concentration of $60 \mathrm{~mol} \% \mathrm{~N}_{2}$ is present. ${ }^{(a)}$ The UFL of $\mathrm{NH}_{3}$ in $\mathrm{N}_{2} \mathrm{O}$ at $60 \mathrm{~mol} \% \mathrm{~N}_{2}$ is $16 \mathrm{~mol} \% \mathrm{NH}_{3}$, somewhat higher than the LFL. When no $\mathrm{N}_{2}$ is present, the UFL in $\mathrm{N}_{2} \mathrm{O}$ of $\mathrm{NH}_{3}$ is $71 \mathrm{~mol} \%$.

The LFL of $\mathrm{CH}_{4}$ in $\mathrm{N}_{2} \mathrm{O}$ increases smoothly, though not quite linearly, from $2.8 \mathrm{~mol} \%$ (with no $\mathrm{N}_{2}$ present) to $6.3 \mathrm{~mol} \%$ when $70 \mathrm{~mol} \% \mathrm{~N}_{2}$ is present (inerting concentration). The UFL of $\mathrm{CH}_{4}$ in $\mathrm{N}_{2} \mathrm{O}$ is $50 \mathrm{~mol} \%$ in the absence of $\mathrm{N}_{2}$ and $6.3 \mathrm{~mol}_{0} \mathrm{CH}_{4}$ (at the inerting concentration).

The effect of $\mathrm{N}_{2}$ on the UFL and LFL of $\mathrm{H}_{2}$ in $\mathrm{N}_{2} \mathrm{O}$ is not known. Nitrogen has little effect on the LFL of $\mathrm{H}_{2}$ in air; the LFL in air is $4 \mathrm{~mol} \%$ with no excess $\mathrm{N}_{2}$ and at the inerting concentration of $\mathrm{N}_{2}{ }^{(b)}$ If the same behavior is assumed for $\mathrm{H}_{2}$ in $\mathrm{N}_{2} \mathrm{O}$, the LFL of $\mathrm{H}_{2}$ in $\mathrm{N}_{2} \mathrm{O}$ would be $3 \mathrm{~mol} \%$ at the inerting concentration of $\mathrm{N}_{2}$ (about $60 \mathrm{~mol} \% \mathrm{~N}_{2}$ ). Because the LFLs and UFLs of the fuel gases in $\mathrm{N}_{2} \mathrm{O}$ vary nearly linearly with $\mathrm{N}_{2}$ concentration, they can be expressed as

$$
\begin{gathered}
{\left[\mathrm{H}_{2}\right]_{\mathrm{LFL}}=0.03} \\
{\left[\mathrm{H}_{2}\right]_{\mathrm{UFL}}=0.84-(0.84-0.03)\left[\mathrm{N}_{2}\right] / 0.6} \\
{\left[\mathrm{NH}_{3}\right]_{\mathrm{LFL}}=0.052+(0.115-0.052)\left[\mathrm{N}_{2}\right] / 0.6} \\
{\left[\mathrm{NH}_{3}\right]_{\mathrm{UFL}}=0.71-(0.71-0.16)\left[\mathrm{N}_{2}\right] / 0.6} \\
{\left[\mathrm{CH}_{4}\right]_{\mathrm{LFL}}=0.028+(0.063-0.028)\left[\mathrm{N}_{2}\right] / 0.7} \\
{\left[\mathrm{CH}_{4}\right]_{\mathrm{UFL}}=0.50-(0.50-0.063)\left[\mathrm{N}_{2}\right] / 0.7}
\end{gathered}
$$

(a) Pfahl U and JE Shepherd April 29. 1997. Flammability and Flame Propagation in $\mathrm{H}_{2}-\mathrm{N}_{2} \mathrm{O}-\mathrm{CH}_{4}-$ $\mathrm{NH}_{3}-\mathrm{O}_{2}-\mathrm{N}_{2}$ Mixtures. Report FM97-4, Explosion Dynamics Laboratory, Pasadena, California.

(b) Shepherd JE. April 30, 1997. "Combustion and Explosion Experiments at Caltech." California Institute of Technology presentation to SCOPE Panel, Richland, Washington. 
The validity of Eq. (3.19) through (3.24) was tested by applying them to gas mixtures whose flammability was measured by other researchers. ${ }^{(a)}$ Mixtures that contained, respectively, $40 \%$ $\mathrm{H}_{2} / 20 \% \mathrm{CH}_{4} / 40 \% \mathrm{~N}_{2} \mathrm{O}$ and $35 \% \mathrm{H}_{2} / 20 \% \mathrm{NH}_{3} / 10 \% \mathrm{CH}_{4} / 35 \% \mathrm{~N}_{2} \mathrm{O}$ were self-flammable, as predicted. A mixture that contained $29 \% \mathrm{H}_{2} / 11 \% \mathrm{NH}_{3} / 1 \% \mathrm{CH}_{4} / 24 \% \mathrm{~N}_{2} \mathrm{O} / 35 \% \mathrm{~N}_{2}$ (intended to simulate SY-101 retained gas) was predicted to be self-flammable but was not. It became flammable when mixed with less than $10 \mathrm{~mol} \%$ air.

Table 3.4 contains an assessment of the self-flammability of the gases from the nonconvective layer(s) of each of the RGS-sampled tanks based on Eq. (3.19) through (3.24) and the RGS retained gas compositions given in Section 2 for the low gas-solubility bound. In 11 of

Table 3.4. Waste Gas Fractions at the LFL in Air/Gas Mixtures

\begin{tabular}{|c|c|c|}
\hline Source of Gas & Composition & Flammability \\
\hline $\begin{array}{l}\text { A-101 } \\
\text { nonconvective }\end{array}$ & $\begin{array}{l}19 \% \mathrm{~N}_{2}, 70 \% \mathrm{H}_{2}, 4.8 \% \mathrm{NH}_{3}, \\
5.7 \% \mathrm{~N}_{2} \mathrm{O}, 0.7 \% \mathrm{CH}_{4}\end{array}$ & $\begin{array}{l}\mathrm{H}_{2} \text { is } 120 \% \text { of the UFL; } \mathrm{NH}_{3} \text { and } \mathrm{CH}_{4} \text { together are } \\
85 \% \text { of the LFL; not self-flammable }\end{array}$ \\
\hline AN-103 crust & $\begin{array}{l}29 \% \mathrm{~N}_{2}, 62 \% \mathrm{H}_{2}, 1.8 \% \mathrm{NH}_{3}, \\
6.9 \% \mathrm{~N}_{2} \mathrm{O}, 0.6 \% \mathrm{CH}_{4}\end{array}$ & $\begin{array}{l}\mathrm{H}_{2} \text { is } 140 \% \text { of the UFL; } \mathrm{NH}_{3} \text { and } \mathrm{CH}_{4} \text { together are } \\
36 \% \text { of the LFL; not self-flammable }\end{array}$ \\
\hline $\begin{array}{l}\text { AN-103 } \\
\text { nonconvective }\end{array}$ & $\begin{array}{l}33 \% \mathrm{~N}_{2}, 61 \% \mathrm{H}_{2}, 0.9 \% \mathrm{NH}_{3}, \\
4.2 \% \mathrm{~N}_{2} \mathrm{O}, 0.6 \% \mathrm{CH}_{4}\end{array}$ & $\begin{array}{l}\mathrm{H}_{2} \text { is } 160 \% \text { of the UFL; } \mathrm{NH}_{3} \text { and } \mathrm{CH}_{4} \text { together are } \\
24 \% \text { of the LFL; not self-flammable }\end{array}$ \\
\hline $\begin{array}{l}\text { AN-104 } \\
\text { nonconvective }\end{array}$ & $\begin{array}{l}29 \% \mathrm{~N}_{2}, 45 \% \mathrm{H}_{2}, 1.4 \% \mathrm{NH}_{3}, \\
23 \% \mathrm{~N}_{2} \mathrm{O}, 0.9 \% \mathrm{CH}_{4}\end{array}$ & $\begin{array}{l}\mathrm{H}_{2} \text { is } 100 \% \text { of the UFL; } \mathrm{NH}_{3} \text { and } \mathrm{CH}_{4} \text { together are } \\
38 \% \text { of the LFL; possibly self-flammable }\end{array}$ \\
\hline $\begin{array}{l}\text { AN-105 } \\
\text { nonconvective }\end{array}$ & $\begin{array}{l}24 \% \mathrm{~N}_{2}, 59 \% \mathrm{H}_{2}, 0.6 \% \mathrm{NH}_{3}, \\
15 \% \mathrm{~N}_{2} \mathrm{O}, 0.7 \% \mathrm{CH}_{4} \\
\end{array}$ & $\begin{array}{l}\mathrm{H}_{2} \text { is } 110 \% \text { of the UFL; } \mathrm{NH}_{3} \text { and } \mathrm{CH}_{4} \text { together are } \\
25 \% \text { of the LFL; not self-flammable }\end{array}$ \\
\hline $\begin{array}{l}\text { AW-101 } \\
\text { nonconvective }\end{array}$ & $\begin{array}{l}55 \% \mathrm{~N}_{2}, 32 \% \mathrm{H}_{2}, 0.9 \% \mathrm{NH}_{3}, \\
7.5 \% \mathrm{~N}_{2} \mathrm{O}, 1.7 \% \mathrm{CH}_{4} \\
\end{array}$ & $\begin{array}{l}\mathrm{H}_{2} \text { is } 330 \% \text { of the UFL; } \mathrm{NH}_{3} \text { and } \mathrm{CH}_{4} \text { together are } \\
39 \% \text { of the LFL; not self-flammable }\end{array}$ \\
\hline $\begin{array}{l}\text { AX-101 } \\
\text { nonconvective }\end{array}$ & $\begin{array}{l}16 \% \mathrm{~N}_{2}, 60 \% \mathrm{H}_{2}, 9.1 \% \mathrm{NH}_{3}, \\
11 \% \mathrm{~N}_{2} \mathrm{O}, 2.4 \% \mathrm{CH}_{4} \\
\end{array}$ & $\begin{array}{l}\mathrm{H}_{2} \text { is } 100 \% \text { of the UFL; } \mathrm{NH}_{3} \text { is } 130 \% \text { of the LFL; } \\
\text { possibly self-flammable }\end{array}$ \\
\hline $\begin{array}{l}\text { BY-109 } \\
\text { nonconvective }\end{array}$ & $\begin{array}{l}28 \% \mathrm{~N}_{2}, 50 \% \mathrm{H}_{2}, 0.3 \% \mathrm{NH}_{3}, \\
18 \% \mathrm{~N}_{2} \mathrm{O}, 0.8 \% \mathrm{CH}_{4} \\
\end{array}$ & $\begin{array}{l}\mathrm{H}_{2} \text { is } 110 \% \text { of the UFL; } \mathrm{NH}_{3} \text { and } \mathrm{CH}_{4} \text { together are } \\
23 \% \text { of the LFL; not self-flammable }\end{array}$ \\
\hline $\begin{array}{l}\text { S-102 } \\
\text { nonconvective }\end{array}$ & $\begin{array}{l}32 \% \mathrm{~N}_{2}, 33 \% \mathrm{H}_{2}, 1.0 \% \mathrm{NH}_{3}, \\
33 \% \mathrm{~N}_{2} \mathrm{O}, 0.4 \% \mathrm{CH}_{4}\end{array}$ & $\begin{array}{l}\mathrm{H}_{2} \text { is } 80 \% \text { of the UFL; } \mathrm{NH}_{3} \text { and } \mathrm{CH}_{4} \text { together are } \\
21 \% \text { of the LFL; self-flammable }\end{array}$ \\
\hline $\begin{array}{l}\text { S-106 } \\
\text { nonconvective }\end{array}$ & $\begin{array}{l}25 \% \mathrm{~N}_{2}, 63 \% \mathrm{H}_{2}, 0.4 \% \mathrm{NH}_{3}, \\
11 \% \mathrm{~N}_{2} \mathrm{O}, 0.3 \% \mathrm{CH}_{4} \\
\end{array}$ & $\begin{array}{l}\mathrm{H}_{2} \text { is } 120 \% \text { of the UFL; } \mathrm{NH}_{3} \text { and } \mathrm{CH}_{4} \text { together are } \\
12 \% \text { of the LFL; not self-flammable }\end{array}$ \\
\hline $\begin{array}{l}\text { S-111 } \\
\text { nonconvective }\end{array}$ & $\begin{array}{l}21 \% \mathrm{~N}_{2}, 66 \% \mathrm{H}_{2}, 1.0 \% \mathrm{NH}_{3}, \\
11 \% \mathrm{~N}_{2} \mathrm{O}, 0.5 \% \mathrm{CH}_{4} \\
\end{array}$ & $\begin{array}{l}\mathrm{H}_{2} \text { is } 120 \% \text { of the UFL; } \mathrm{NH}_{3} \text { and } \mathrm{CH}_{4} \text { together are } \\
26 \% \text { of the LFL; not self-flammable }\end{array}$ \\
\hline $\begin{array}{l}\text { SX-106 } \\
\text { nonconvective }\end{array}$ & $\begin{array}{l}20 \% \mathrm{~N}_{2}, 51 \% \mathrm{H}_{2}, 4.4 \% \mathrm{NH}_{3}, \\
24 \% \mathrm{~N}_{2} \mathrm{O}, 0.6 \% \mathrm{CH}_{4}\end{array}$ & $\begin{array}{l}\mathrm{H}_{2} \text { is } 90 \% \text { of the UFL; } \mathrm{NH}_{3} \text { and } \mathrm{CH}_{4} \text { together are } \\
76 \% \text { of the LFL; self-flammable }\end{array}$ \\
\hline SY-101 crust & \begin{tabular}{|l|}
$27 \% \mathrm{~N}_{2}, 34 \% \mathrm{H}_{2}, 19 \% \mathrm{NH}_{3}$ \\
$19 \% \mathrm{~N}_{2} \mathrm{O}, 0.6 \% \mathrm{CH}_{4}$ \\
\end{tabular} & $\begin{array}{l}\mathrm{H}_{2} \text { is } 70 \% \text { of the UFL; } \mathrm{NH}_{3} \text { is } 240 \% \text { of the LFL; } \\
\text { self-flammable }\end{array}$ \\
\hline $\begin{array}{l}\mathrm{U}-103 \\
\text { nonconvective }\end{array}$ & $\begin{array}{l}36 \% \mathrm{~N}_{2}, 23 \% \mathrm{H}_{2}, 0.6 \% \mathrm{NH}_{3}, \\
40 \% \mathrm{~N}_{2} \mathrm{O}, 0.4 \% \mathrm{CH}_{4}\end{array}$ & $\begin{array}{l}\mathrm{H}_{2} \text { is } 65 \% \text { of the UFL; } \mathrm{NH}_{3} \text { and } \mathrm{CH}_{4} \text { together are } \\
15 \% \text { of the LFL; self-flammable }\end{array}$ \\
\hline $\begin{array}{l}\mathrm{U}-109 \\
\text { nonconvective }\end{array}$ & $\begin{array}{l}46 \% \mathrm{~N}_{2}, 25 \% \mathrm{H}_{2}, 0.9 \% \mathrm{NH}_{3}, \\
27 \% \mathrm{~N}_{2} \mathrm{O}, 0.7 \% \mathrm{CH}_{4}\end{array}$ & $\begin{array}{l}\mathrm{H}_{2} \text { is } 110 \% \text { of the UFL; } \mathrm{NH}_{3} \text { and } \mathrm{CH}_{4} \text { together are } \\
23 \% \text { of the LFL; not self-flammable }\end{array}$ \\
\hline
\end{tabular}

(a) Pfahl U and JE Shepherd. April 29, 1997. Flammability and Flame Propagation in $\mathrm{H}_{2}-\mathrm{N}_{2} \mathrm{O}-\mathrm{CH}_{4}-$ $\mathrm{NH}_{3}-\mathrm{O}_{2}-\mathrm{N}_{2}$ Mixtures. Report FM97-4, Explosion Dynamics Laboratory, Pasadena, California. 
the 15 cases, the $\mathrm{H}_{2}$ mole fraction is equal to or greater than the UFL for the mixture. Because the mixture UFLs are not precisely defined, any mixture in which $\mathrm{H}_{2}$ is less than $110 \%$ of the UFL is considered potentially self-flammable. Of the 15 wastes listed, nine retain gas that contains too little oxidant to be self-flammable.

The gases in the $\mathrm{AN}-104$ and $\mathrm{AX}-101$ nonconvective layers contain borderline concentrations of $\mathrm{H}_{2}$ and may be self-flammable. However, the total fuel/oxidant ratio (including $\mathrm{NH}_{3}$ and $\mathrm{CH}_{4}$ as fuels) may be too large to allow combustion, particularly for the higher- $\mathrm{NH}_{3} \mathrm{AX}-101$ waste. In the four remaining wastes (S-102, SX-106, SY-101, and U-103), $\mathrm{H}_{2}$ is below the UFL and the gas is self-flammable. Considering that the UFL model in Eq. (3.19) through (3.24) overpredicts the UFL, thereby increasing the range of mixtures that are modeled as self-flammable, it is possible that some of the waste gases would not actually exhibit self-flammability even though it was predicted.

It cannot be overstressed that this self-flammability assessment considers only the intrinsic properties of the gas mixture, as if the gas were contained in a large vessel rather than in the pores, bubbles, or fissures in the waste matrix. The assessment does not consider the amount of ignition energy required to initiate combustion. Many of the data used to support the flammability estimate were obtained with ignition energies of $8 \mathrm{~J}$ or more, which would be unusually high energies for accidental sparks $(20 \mathrm{~mJ}$ energies are typically seen in static sparks on clothing). The self-flammability assessment also does not consider whether interconnected pathways exist in the waste to permit flame propagation or whether heat loss to the walls of a small passage would prevent propagation. All of these limiting factors make flame propagation within the waste implausible, as is discussed in Section 4.

\subsection{Conclusions}

The following conclusions were drawn from this flammability research:

- The upward propagation LFL for a gas mixture obeyed LeChatelier's linear mixing law (Eq. 3.17 and 3.18)

- Nitrous oxide is inert in $\mathrm{H}_{2}$ combustion below the downward propagation limit of 8 $\mathrm{mol} \% \mathrm{H}_{2}$

- Nitrous oxide participates in $\mathrm{NH}_{3}$ and $\mathrm{CH}_{4}$ combustion at their LFLs and affects both the UFL and the LFL

- Neither water vapor nor waste-gas $\mathrm{N}_{2}$ can be counted on to prevent combustion in tank headspaces or in the waste itself in every tank

- In many wastes, there is not enough $\mathrm{N}_{2} \mathrm{O}$ to support combustion in the absence of air.

Overall, $\mathrm{H}_{2}$ dominates the flammability issue even at relatively low concentrations, and flammability limits for $\mathrm{H}_{2}$ in the presence of other fuel gases can be readily calculated. 


\subsection{Deflagration and Detonation}

When a gas mixture is exposed to an ignition source that is energetic enough to initiate combustion, the resulting flame propagation may be either by subsonic deflagration or supersonic detonation. This section reviews experimental studies of the outcome of ignition of such gas mixtures and discusses the parameters that govern whether deflagration or detonation could result.

Deflagration is subsonic flame propagation away from the ignition site. The peak pressure caused by combustion is essentially uniform throughout an enclosure and depends on the completeness of combustion, the resulting adiabatic flame temperature, and the increase (or decrease) in the number of moles of gas dictated by the combustion reaction stoichiometry. A detonation involves supersonic flame propagation. The peak pressure of a detonation is localized at the shock wave moving through the gas mixture. For a given gas mixture, a deflagration and a detonation may both release the same amount of energy, but the peak pressure of the detonation shock wave is approximately double that of the deflagration and the reflection of the shock wave can produce pressures more than twice as high as those in the shock wave itself (Zalosh 1988). An additional concern is that venting cannot effectively reduce the short-duration peak pressure of a detonation. The response time of the enclosure structure also affects the relative damage produced by deflagrations and detonations.

While the possibility of deflagration in an open space (such as the headspace of a waste tank) is defined purely by the composition of the gas it contains, the possibility of detonation is defined both by the gas composition and the dimensions of the space. In general, either a high length-to-diameter ratio is needed to allow a deflagration to make the transition to detonation or a very high ignition energy is needed to directly produce a detonation.

It is possible for both deflagrations and detonations to be transmitted within the pores of a porous medium or from an open space to the pores. (For assessing Hanford waste, "pores" denotes not only pores between particles but also other larger cracks and bubble networks.) Propagation of detonation in pores, like flame propagation, requires that the pore diameter be greater than some minimum value. The minimum pore diameter is larger (more constraining) for detonation than for deflagration. However, to a large extent, the question of in-pore propagation is moot because most Hanford wastes do not consist of porous media in the sense of a globally interconnecting network of passages but of separated bubbles or small isolated networks.

\subsection{Deflagration in Open Spaces}

The potential for deflagration in the open spaces of a tank, such as the headspace itself and the volumes of risers and other tank apparatus, is determined by the flammability of the gas mixture and its associated minimum ignition energy. Both the flame speeds and the peak pressures generated by deflagration are significant in defining the effect of a deflagration on the tank waste and structure.

Flame propagation into a quiescent mixture begins as a laminar spherical front, but turbulence, whether induced by the motion of the front itself or by other gas motion, increases 
both the burning velocity and the surface area of the front. Studies have measured the laminar burning velocity for lean waste gas/air mixtures including a number of gas mixtures relevant to the Hanford waste retained gases. ${ }^{(a, b)}$ There were few burning velocity data for the fuel-rich range and no data for mixtures in which $\mathrm{N}_{2} \mathrm{O}$ was the only oxidant. Figure 4.1 summarizes the experimental results.

The data show that the burning velocity generally increases as the fraction of fuel in the gas increases. An increase in the amount of $\mathrm{H}_{2}$ in the waste gas proportionally increases the burning velocity in the lower half of the fuel-fraction range shown in Figure 4.1. This effect can be seen by comparing the behavior of $\mathrm{H}_{2}$ alone with that of the mixtures containing varying amounts of $\mathrm{H}_{2}$. Methane, when present as $10 \mathrm{~mol} \%$ or more of the waste gas, apparently also increases the

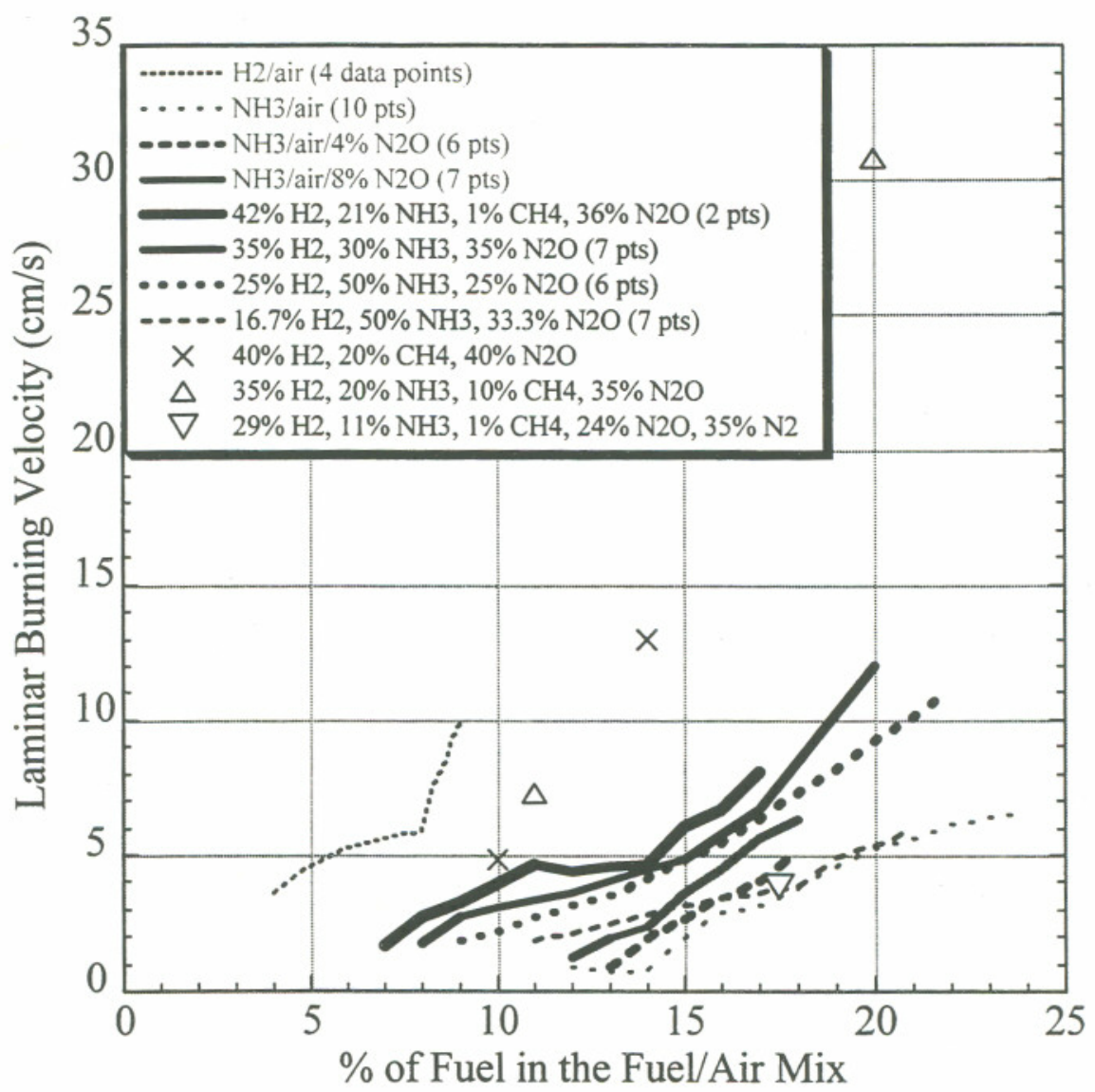

Figure 4.1. Laminar Burning Velocities for Gas/Air Mixtures

(a) Ross MC and JE Shepherd. July 1996. Lean Combustion Characteristics of Hydrogen-Nitrous Oxide-Ammonia Mixtures in Air, Part I. Report FM96-4, Explosion Dynamics Laboratory, Pasadena, California.

(b) Pfahl U and JE Shepherd. July 1997. Flammability, Ignition Energy, and Flame Speeds in $\mathrm{NH}_{3}-\mathrm{H}_{2}-$ $\mathrm{CH}_{4}-\mathrm{N}_{2} \mathrm{O}-\mathrm{O}_{2}-\mathrm{N}_{2}$ Mixtures. Report FM97-4R1, Explosion Dynamics Laboratory, Pasadena, California. 
burning velocity, though this high a methane concentration has never been measured in Hanford wastes. As the waste gas fraction increases, $\mathrm{NH}_{3}$ and mixtures containing primarily $\mathrm{NH}_{3}$ do not show as pronounced an increase in burning velocity as the lower- $\mathrm{NH}_{3}$, higher- $\mathrm{H}_{2}$ mixtures. It is also clear that the burning velocity of $\mathrm{NH}_{3}$ is higher in the presence of $\mathrm{N}_{2} \mathrm{O}$ than in pure air, and that high $\mathrm{N}_{2}$ (as in the last mixture listed in the figure's legend) tends to reduce the burning velocity.

The cited references contain a few measurements that indicate that higher burning velocities than those shown in Figure 4.1 are possible. When $75 \%$ of the mixture comprising $40 \% \mathrm{H}_{2}, 20 \%$ $\mathrm{CH}_{4}$, and $40 \% \mathrm{~N}_{2} \mathrm{O}$ was burned in a fuel-rich regime in air, the burning velocity was $45 \mathrm{~cm} / \mathrm{s}$. Turbulent burning is another situation in which high burning velocities were seen. For the same implausibly high- $\mathrm{CH}_{4}$ mixture, lower-bound turbulent burning velocities of $60 \mathrm{~cm} / \mathrm{s}$ were measured at fuel fractions of about 25 and $50 \%$. At the lean end of the flammability range $(15 \%$ fuel and less), the turbulent velocities were about double the laminar velocities. At the rich end ( $75 \%$ fuel), the turbulent velocity was not much greater than the laminar $-50 \mathrm{~cm} / \mathrm{s}$ compared with $45 \mathrm{~cm} / \mathrm{s}$.

The measured peak pressure from a deflagration is often compared with the pressure predicted by assuming adiabatic, isochoric ${ }^{(a)}$ complete combustion (the AICC pressure). In general, measured peak pressures ${ }^{(\mathrm{b}, \mathrm{c})}$ were nearly equal to the AICC pressure when the fuel concentration was above the downward propagation LFL and were low when the fuel concentration was at the upward propagation LFL (Slezak et al. 1998). The increase in peak pressure with fuel concentration followed an S-shaped curve. The peak pressures were less than $10 \mathrm{bar}$ in all measurements made with air as the primary oxidant, where the fuel gases included $\mathrm{H}_{2}, \mathrm{NH}_{3}$, and $\mathrm{CH}_{4}$. Peak pressures of about 12 bar were measured for low concentrations of $\mathrm{NH}_{3}$ ( $8 \mathrm{~mol} \%$ or less) in $\mathrm{N}_{2} \mathrm{O}$ with no air present.

In $\mathrm{H}_{2}-\mathrm{N}_{2} \mathrm{O}$-air mixtures near the downward propagation LFL, the peak pressures remained equal to about $85 \%$ of the AICC pressure for $\mathrm{H}_{2}$-air mixtures, though as much as $18 \% \mathrm{~N}_{2} \mathrm{O}$ was added. As was already noted in Section 3.1, $\mathrm{N}_{2} \mathrm{O}$ does not react completely in $\mathrm{H}_{2}$-air mixtures until $\mathrm{H}_{2}$ reaches about $10 \mathrm{~mol} \%$.

In $\mathrm{NH}_{3}$-air mixtures, the peak pressures under turbulent conditions were about $85 \%$ of the AICC pressures for $\mathrm{NH}_{3}$ concentrations above $16 \mathrm{~mol} \%$. However, under quiescent conditions the peak pressures followed the typical S-shape. They were only a little above the initial pressure for $18 \mathrm{~mol}^{2} \mathrm{NH}_{3}$ or less, while the peak pressures were about $60 \%$ of AICC pressure for $\mathrm{NH}_{3}$ of $20 \mathrm{~mol} \%$ or more. As with the burning velocity, the peak pressure is substantially increased by turbulence (in this case, produced by a fan). Like turbulence, $\mathrm{N}_{2} \mathrm{O}$ addition caused a decrease in the $\mathrm{NH}_{3}$ concentration at which higher peak pressures appeared in combustion of $\mathrm{NH}_{3}$-air mixtures (that is, the rise in the "S" curve occurred at lower $\mathrm{NH}_{3}$ ).

(a) isochoric $=$ constant volume.

(b) Ross MC and JE Shepherd. July 1997. Lean Combustion Characteristics of Hydrogen-Nitrous Oxide-Ammonia Mixtures in Air, Part I. Report FM96-4, Explosion Dynamics Laboratory, Pasadena, California.

(c) Pfahl U and JE Shepherd. July 1997. Flammability, Ignition Energy, and Flame Speeds in $\mathrm{NH}_{3}-\mathrm{H}_{2}-$ $\mathrm{CH}_{4}-\mathrm{N}_{2} \mathrm{O}-\mathrm{O}_{2}-\mathrm{N}_{2}$ Mixtures. Report FM97-4R1, Explosion Dynamics Laboratory, Pasadena, California. 
Turbulence had much the same effect on $\mathrm{H}_{2}-\mathrm{N}_{2} \mathrm{O}-\mathrm{NH}_{3}$ mixtures combined with air as on combinations of single fuel gases and air. Under turbulent conditions in a mixture of $42 \% \mathrm{H}_{2}$, $21 \% \mathrm{NH}_{3}, 36 \% \mathrm{~N}_{2} \mathrm{O}$, and $1 \% \mathrm{CH}_{4}$, the peak pressure rose from the initial pressure at $7 \mathrm{vol} \%$ gas to about $90 \%$ of the AICC pressure at $15 \mathrm{~mol} \%$ gas (and remained at that fraction of the AICC pressure for higher gas concentrations). Under quiescent conditions, the same gas mixture remained at the initial pressure even at a concentration of $15 \mathrm{~mol} \%$ gas, then rose to about $80 \%$ of the AICC pressure at $17 \mathrm{~mol} \%$ gas. Turbulence decreased the steepness of the slope in the "S" curve and moved it to lower gas concentrations. Similar turbulence effects were exhibited by a number of other mixtures that contained $\mathrm{H}_{2}, \mathrm{~N}_{2} \mathrm{O}$, and $\mathrm{NH}_{3}$.

The magnitudes of peak pressures under turbulent conditions can be summarized in the following way. The peak pressures were less than $10 \mathrm{bar}$ in all measurements made with more than $80 \mathrm{vol} \%$ air, where the fuel gases included $\mathrm{H}_{2}, \mathrm{NH}_{3}$, and $\mathrm{CH}_{4}$. Peak pressures of 12 to 13 bar were measured for low concentrations of $\mathrm{NH}_{3}$ ( $8 \mathrm{~mol} \%$ or less) in $\mathrm{N}_{2} \mathrm{O}$ with no air present. Lean $\mathrm{CH}_{4} / \mathrm{N}_{2} \mathrm{O}$ mixtures (less than 8 vol\% $\mathrm{CH}_{4}$ ) also produced peak pressures in the 12 to 13 bar range. When large amounts of $\mathrm{N}_{2}\left(60 \%\right.$ or more) were added to lean $\mathrm{NH}_{3} / \mathrm{N}_{2} \mathrm{O}$ and $\mathrm{CH}_{4} / \mathrm{N}_{2} \mathrm{O}$ mixtures, the peak pressure was reduced by about $30 \%$, depending on how much $\mathrm{N}_{2}$ was present. A mixture that contained $35 \mathrm{~mol} \% \mathrm{H}_{2}, 20 \mathrm{~mol} \% \mathrm{NH}_{3}, 35 \mathrm{~mol} \% \mathrm{~N}_{2} \mathrm{O}$, and $10 \mathrm{~mol} \%$ $\mathrm{CH}_{4}$ produced a peak pressure of 4 bar at $12 \mathrm{vol} \%$ in air, $10 \mathrm{bar}$ at $50 \mathrm{vol} \%$ in air, and $11 \mathrm{bar}$ in the absence of air. These peak pressures were 80 to $90 \%$ of the AICC pressures. A partially inerted mixture that contained $29 \mathrm{~mol} \% \mathrm{H}_{2}, 11 \mathrm{~mol} \% \mathrm{NH}_{3}, 24 \mathrm{~mol} \% \mathrm{~N}_{2} \mathrm{O}, 1 \mathrm{~mol} \% \mathrm{CH}_{4}$, and $35 \mathrm{~mol} \% \mathrm{~N}_{2}$ produced a peak pressure of 4 bar at about $22 \mathrm{vol} \%$ in air and 9 bar at $90 \mathrm{vol} \%$ in air. It was not flammable in the absence of air.

In general, measurements showed that it was typical for the peak pressure to be $90 \%$ or less of the AICC values and to be greater than four times the initial pressure. The presence of turbulence increased the peak pressure. The presence of $\mathrm{N}_{2} \mathrm{O}$ also increased peak pressures while inerting with $\mathrm{N}_{2}$ produced significant reductions in peak pressure.

\subsection{Deflagration Within Waste}

As detailed by Stewart et al. (1996), the gas retained by Hanford waste is present in several different forms:

- small bubbles or bubble/solid aggregates in the liquid in convective layers

- particle-displacing bubbles that may be isolated (in low-strength wet waste) or connected in networks of limited extent (in high-strength wet waste)

- pore-filling bubbles, again in networks of limited extent, probably only present in wet waste with pore diameters on the order of $100 \mu \mathrm{m}$

- pores at the top of dry waste that are primarily air-filled but through which is diffusing gas generated in the lower, wetter waste.

Combustion propagation is not considered possible for most of these forms of retained gas. Gas in the convective layer is not capable of combustion, being surrounded by liquid. The same is probably true for isolated particle-displacing bubbles. The possibility of deflagration in dry 
waste pores that are open to the air, and therefore contain a gas-air mixture, has been considered and shown to be implausible. Stewart et al. (1996) showed that, in Hanford waste, even with conservatively high gas generation rates, diffusion dilutes the gas in open pores far below flammability. Slezak et al. (1998) demonstrated that it was not possible for waste to both retain gas at potentially flammable concentrations and have pores large enough to support flame propagation. The large pores (high permeability) would allow gas to escape by diffusion, reducing the gas concentration in the pores below flammable levels. In addition, the burning velocities might well be lower in gas-air mixtures than in waste gas alone, making the propagation of flame more difficult in pores that were open to the air. Since the gas in the pores in dry waste will not support combustion, deflagrations cannot propagate from the headspace into the waste.

Depending on the self-flammability of the gas, the diameter of the passages in the bubble network, and the availability of an ignition source, the gas in submerged bubble networks might in theory support combustion. However, the extent of theoretically possible burn propagation is small; waste strength and hydrostatic considerations limit the extent of bubble networks to $1 \mathrm{~m}$ or less vertically, and no more than thrice their height horizontally (Stewart et al. 1996). "Fracture bubbles" may exist in the region between the lithodendritic lower waste and the hydrodendritic upper waste. The maximum height of these bubbles is on the order of centimeters (depending on waste strength), and their maximum diameter is believed to be less than 10 times the height.

Studies of pore space deflagration have included experiments with flame propagation in tubes as well as experiments in porous media. ${ }^{(a)}$ The experiments in porous media have been conducted with particles of uniform size and shape in the absence of water (which is expected to mitigate combustion). The tank wastes are wet, and the passages are of a range of sizes and shapes. Because of these differences, and because experimental gases have typically been hydrocarbon-air mixtures rather than $\mathrm{H}_{2}-\mathrm{NH}_{3}-\mathrm{N}_{2} \mathrm{O}-\mathrm{N}_{2}$ mixtures, there is uncertainty and probably considerable conservatism in application of these experimental results to tank waste modeling.

The theoretical potential for deflagration in the pore space of a porous medium is defined not only by the flammability of the gas and the ignition energy but also by the Peclet number. The Peclet number is defined as

$$
P e=\frac{S_{L} c_{p} \rho d_{m}}{k}
$$

where $S_{L}$ is the laminar burning velocity of the gas, $d_{m}$ the equivalent pore diameter, $c_{p}$ the specific heat capacity of the gas, $\rho$ the density of the gas, and $k$ the thermal conductivity of the gas. $^{(a)}$ For any flammable gas mixture there is a critical Peclet number (pore diameter) below which propagation of the deflagration is not possible. The minimum Peclet number for flame propagation (critical Peclet number), $\mathrm{Pe}^{*}$, through a tube was found experimentally to be 85

(a) Pfahl U, JE Shepherd, and C Unal. February 23, 1998. Combustion Within Porous Waste. Report FM97-18, Explosion Dynamics Laboratory, Pasadena, California. 
(Lyamin and Pinaev 1985). Experiments conducted by Trimis and Durst (1996) in a dry porous medium found $\mathrm{Pe}^{*}=65$.

Using a critical Peclet number of 65 , standard properties for the constituent gases, and a range of laminar burning velocities, we obtained the estimates of minimum equivalent pore diameter for flame propagation that are given in Table 4.1. The burning velocity is uncertain for waste gas mixtures in the absence of air: a lower end value of $10 \mathrm{~cm} / \mathrm{s}$ can be seen in the velocities measured at moderate concentrations of fuel in air, as in Figure 4.1. Other references have used a burning velocity of $100 \mathrm{~cm} / \mathrm{s}$ as a basis for estimates. ${ }^{\text {(a) }}$

Table 4.1. Minimum Pore Diameter to Allow Deflagration in Pores

\begin{tabular}{|c|c|c|c|}
\hline \multirow[b]{2}{*}{ Source of Gas } & \multirow{2}{*}{$\begin{array}{c}\mathrm{k} / \mathrm{c}_{\mathrm{p}} \rho \\
\left(\mathrm{cm}^{2} / \mathrm{s} @ 40^{\circ} \mathrm{C}\right)\end{array}$} & \multicolumn{2}{|c|}{ Minimum Equivalent Pore Diameter (mm) } \\
\hline & & for $S_{L}=10 \mathrm{~cm} / \mathrm{s}$ & for $S_{L}=100 \mathrm{~cm} / \mathrm{s}$ \\
\hline A-101 nonconvective & 0.34 & 22 & 2.2 \\
\hline AN-103 crust & 0.28 & 18 & 1.8 \\
\hline AN-103 nonconvective & 0.28 & 18 & 1.8 \\
\hline AN-104 nonconvective ${ }^{(a)}$ & $0.19^{(\mathrm{a})}$ & $12^{(\mathrm{a})}$ & $1.2^{(\mathrm{a})}$ \\
\hline AN-105 nonconvective & 0.24 & 16 & 1.6 \\
\hline AW-101 nonconvective & 0.19 & 12 & 1.2 \\
\hline $\mathrm{AX}-101$ nonconvective ${ }^{(\mathrm{a})}$ & $0.28^{(a)}$ & $18^{(\mathrm{a})}$ & $1.8^{(\mathrm{a})}$ \\
\hline BY-109 nonconvective & 0.21 & 14 & 1.4 \\
\hline S-102 nonconvective ${ }^{(a)}$ & $0.15^{(\mathrm{a})}$ & $10^{(\mathrm{a})}$ & $1.0^{(\mathrm{a})}$ \\
\hline S-106 nonconvective & 0.27 & 17 & 1.7 \\
\hline S-111 nonconvective & 0.29 & 19 & 1.9 \\
\hline SX-106 nonconvective ${ }^{(a)}$ & $0.20^{(a)}$ & $13^{(\mathrm{a})}$ & $1.3^{(\mathrm{a})}$ \\
\hline SY-101 crust $^{(a)}$ & $0.18^{(a)}$ & $12^{(\mathrm{a})}$ & $1.2^{(\mathrm{a})}$ \\
\hline U-103 nonconvective ${ }^{(a)}$ & $0.14^{(\mathrm{a})}$ & $9.0^{(a)}$ & $0.90^{(\mathrm{a})}$ \\
\hline U-109 nonconvective & 0.15 & 10 & 1.0 \\
\hline
\end{tabular}

The pores must be greater than about $1 \mathrm{~mm}$ in equivalent diameter for the potentially selfflammable gases to deflagrate in the pores. The presence of fracture bubbles or bubble networks in waste would increase the equivalent pore size above what would be expected from the typical particle size of $0.1 \mathrm{~mm}$ or less. Based on the current understanding of retained gas morphology, flame propagation within the waste in a region of limited extent cannot be ruled out. Such a region might comprise a bubble network or a fracture bubble with a horizontal extent of as much as a meter.

\subsection{Detonation in Headspace}

The potential for detonation in the open spaces of a tank, such as in the headspace itself and the volumes of risers and other tank apparatus, is defined by the detonation cell width. The larger the cell width, the less the potential for detonation. The detonation cell width, $\lambda$, is the measured transverse dimension of the cells generated by the wave structure at the detonation 
front and reliably characterizes the detonability of a gas mixture. The cell width is typically measured from the pattern left on a sooted foil by a detonation.

The detonation cell width depends on the properties of the gas. It decreases as the initial pressure increases and varies along a $U$-shaped curve as the fuel/oxidizer ratio increases. The cell width is typically high near the lower and upper flammability limits and reaches a much lower minimum near the stoichiometric fuel/oxidizer ratio, as shown in Figure 4.2. ${ }^{\text {(a) }}$ The effect of diluents such as $\mathrm{N}_{2}$ is to increase $\lambda$ throughout the range of fuel/oxidizer ratios and narrow the range of fuel/oxidizer ratios for which detonation is possible. Cell widths usually increase monotonically as diluent increases.

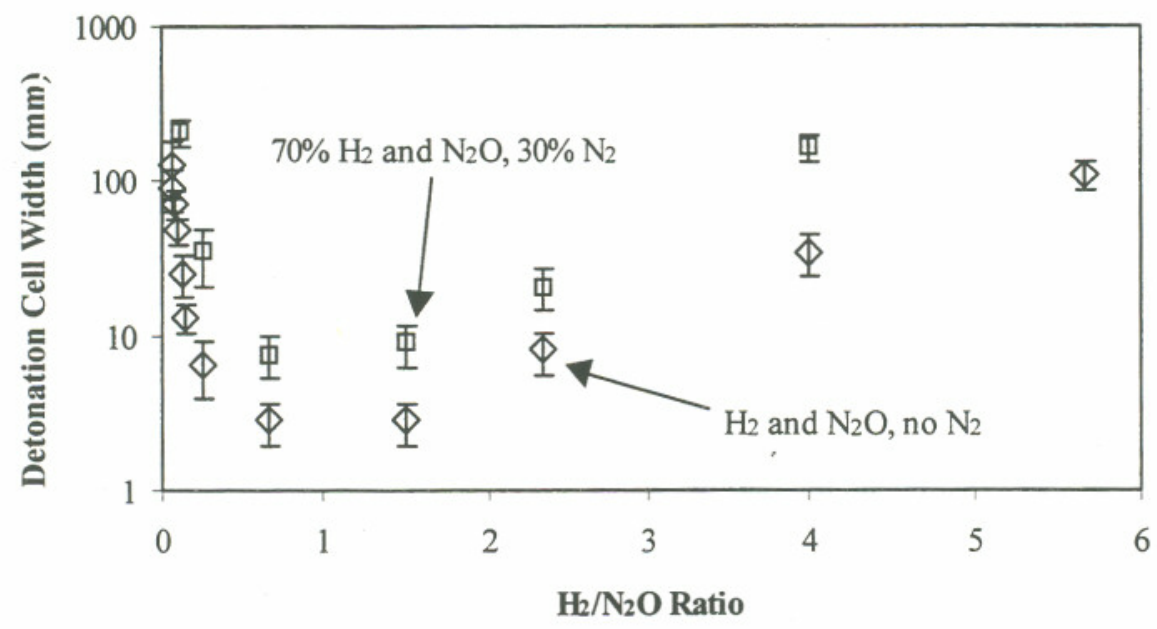

Figure 4.2. Typical Variation of Detonation Cell Widths with Composition

Detonation cell width measurements have been made for a variety of gas mixtures similar to those in the gases retained in Hanford waste tanks. ${ }^{\text {(a) }}$ The measurements were made at initial pressures of 0.7 to $1 \mathrm{~atm}$ using an extremely high ignition energy of $10 \mathrm{~kJ}$ or more. The results, which have been adjusted to $1 \mathrm{~atm}$ pressure by Slezak et al. (1998), are shown in Table 4.2.

As shown in Table 4.2, the mixtures representing SY-101 gas tended to maintain constant, relatively small $\lambda$ values for air in the range from $0 \%$ to $40 \%$ air. When air was further increased, the cell width increased dramatically. This behavior occurred because the SY-101 mixtures were fuel-rich. The sparseness of measurements for the gas mixtures representing A-101, the three AN tanks, and AW-101 leaves it unclear whether they would show similar behavior.

The SY-101 mixtures gave substantially larger values of $\lambda$ than the $\mathrm{H}_{2} / \mathrm{N}_{2} \mathrm{O}$ mixtures for similar amounts of dilution with air. The increase in cell width probably resulted from the presence of $\mathrm{NH}_{3}$ and (to a lesser extent) of $\mathrm{CH}_{4}$. The cell width was considerably greater at low dilution for the SY-101 mixture with $\mathrm{N}_{2}$ than for the mixture without $\mathrm{N}_{2}$, indicating the effect of

(a) Pfahl U, E Schultz, and JE Shepherd. April 10, 1998. Detonation Cell Width Measurements for $\mathrm{H}_{2}-$ $\mathrm{N}_{2} \mathrm{O}-\mathrm{N}_{2}-\mathrm{O}_{2}-\mathrm{CH}_{4}-\mathrm{NH}_{3}$ Mixtures. Report FM98-5, Explosion Dynamics Laboratory, Pasadena, California. 
waste gas $\mathrm{N}_{2}$. The tendency of $\mathrm{N}_{2}$ to reduce detonability (i.e., to increase $\lambda$ ) can also be seen in the results for the mixture representing AW-101.

From the data presented in Table 4.2 as well as other data, ${ }^{(a)}$ the following general conclusions were drawn:

- Cell widths for $\mathrm{H}_{2}$ and $\mathrm{CH}_{4}$ were slightly smaller for $\mathrm{O}_{2}$ as the oxidizer than for $\mathrm{N}_{2} \mathrm{O}$. However, when $\mathrm{NH}_{3}$ was the fuel, $\mathrm{N}_{2} \mathrm{O}$ as oxidizer produced cell widths that were a factor of two smaller than for $\mathrm{O}_{2}$.

- At stoichiometric fuel/oxidizer ratios, $\mathrm{CH}_{4}$ produced cell widths that were two to four times larger than produced by $\mathrm{H}_{2}$, and $\mathrm{NH}_{3}$ cell widths were a factor of 10 or more larger than those for $\mathrm{H}_{2}$. Additions of as little as $3 \% \mathrm{CH}_{4}$ or $\mathrm{NH}_{3}$ significantly increased the cell widths over the value found for $\mathrm{H}_{2} / \mathrm{N}_{2} \mathrm{O}$ mixtures.

- Air dilution produced slightly smaller cell widths in $\mathrm{H}_{2}$ and $\mathrm{CH}_{4}$ mixtures than $\mathrm{N}_{2}$ dilution, with no apparent difference between air and $\mathrm{N}_{2}$ dilution for $\mathrm{NH}_{3}$.

- Dilution of 65 to $80 \%$ air or $\mathrm{N}_{2}$ was sufficient to give cell widths of $100 \mathrm{~mm}$ for all stoichiometric fuel/oxidizer combinations except $\mathrm{NH}_{3} / \mathrm{O}_{2}$, for which $35 \%$ dilution with $\mathrm{N}_{2}$ sufficed. However, fuel-rich mixtures (such as the simulated gases for AN-103 and A-101) had cell widths well below $100 \mathrm{~mm}$ when diluted $65 \%$ by air.

Detonations can be directly caused by very high ignition energies. The minimum energy to produce a detonation in a stoichiometric mixture of $\mathrm{H}_{2}$ and air is $5 \mathrm{~kJ}$ (Zalosh 1988). Even higher energies are required for non-stoichiometric mixtures, or for the other fuels in the tank waste gas. (The minimum detonation energies for fuels in a $\mathrm{N}_{2} \mathrm{O}$ atmosphere are not known.) Under some circumstances, a deflagration flame can accelerate and become a detonation (referred to as a deflagration-detonation transition, or DDT). This is a more common source of detonations than direct induction. In general, for a DDT to occur in an enclosure, the enclosure must have a high length-to-diameter ratio (30 to 100); however, DDTs have been observed in shorter enclosures, and the prediction of DDTs remains uncertain (Zalosh 1988). The geometry of waste tank headspace would probably not encourage a DDT, except in the case of unusually high turbulence or if the volume was constricted by large installed hardware (e.g., a large number of airlift circulators).

If ignition were to occur inside equipment that provided a high length-to-diameter ratio, a DDT could result. The detonation in the equipment could not propagate into the headspace unless the piping in the equipment had a diameter greater than the critical diameter $d_{c}$. According to Zalosh (1988), the critical diameter for this configuration is

$$
\mathrm{d}_{\mathrm{c}}=13 \lambda \quad \text { (propagate from pipe to open space) }
$$

(a) Pfahl U, E Schultz, JE Shepherd. April 10, 1998. Detonation Cell Width Measurements for $\mathrm{H}_{2}-\mathrm{N}_{2} \mathrm{O}$ $\mathrm{N}_{2}-\mathrm{O}_{2}-\mathrm{CH}_{4}-\mathrm{NH}_{3}$ Mixtures. Report FM98-5, Explosion Dynamics Laboratory, Pasadena, California. 
Table 4.2. Detonation Cell Widths for Various Dilutions

\begin{tabular}{|c|c|c|c|c|}
\hline Mixture & Diluent & Condition & Dilution & $\begin{array}{l}\text { Detonation Cell } \\
\text { Width (mm) }\end{array}$ \\
\hline $\begin{array}{l}\text { stoichiometric } \mathrm{H}_{2} / \mathrm{N}_{2} \mathrm{O} \\
(1: 1)\end{array}$ & air & $\begin{array}{l}\text { No dilution } \\
\text { Maximum measured dilution }\end{array}$ & $\begin{array}{l}0 \% \\
50 \% \\
76 \%\end{array}$ & $\begin{array}{c}0.9-1.9 \\
5-11 \\
92-122\end{array}$ \\
\hline $\begin{array}{l}\text { stoichiometric } \mathrm{H}_{2} / \mathrm{N}_{2} \mathrm{O} \\
(1: 1)\end{array}$ & $\mathrm{N}_{2}$ & $\begin{array}{l}\text { No dilution } \\
\text { Maximum measured dilution }\end{array}$ & $\begin{array}{c}0 \% \\
50 \% \\
70 \%\end{array}$ & $\begin{array}{c}0.9-1.9 \\
10-18 \\
100-335\end{array}$ \\
\hline $\begin{array}{l}42 \% \mathrm{H}_{2}, 21 \% \mathrm{NH}_{3}, 36 \% \\
\mathrm{~N}_{2} \mathrm{O}, 1 \% \mathrm{CH}_{4} \\
\left(\mathrm{SY}-101 \text { without } \mathrm{N}_{2} \text { ) }\right.\end{array}$ & air & $\begin{array}{l}\text { No dilution } \\
\text { Maximum measured dilution }\end{array}$ & $\begin{array}{l}0 \% \\
50 \% \\
75 \%\end{array}$ & $\begin{array}{c}7-11 \\
10-18 \\
75-181\end{array}$ \\
\hline $\begin{array}{l}29 \% \mathrm{H}_{2}, 11 \% \mathrm{NH}_{3}, 24 \% \\
\mathrm{~N}_{2} \mathrm{O}, 1 \% \mathrm{CH}_{4}, 35 \% \mathrm{~N}_{2} \\
\text { (SY-101) }\end{array}$ & air & $\begin{array}{l}\text { No dilution } \\
\text { Maximum measured dilution }\end{array}$ & $\begin{array}{l}0 \% \\
41 \% \\
60 \%\end{array}$ & $\begin{array}{c}19-35 \\
16-39 \\
92-108\end{array}$ \\
\hline $\begin{array}{l}31 \% \mathrm{H}_{2}, 0.02 \% \mathrm{NH}_{3}, \\
4.3 \% \mathrm{~N}_{2} \mathrm{O}, 1.6 \% \mathrm{CH}_{4}, \\
63 \% \mathrm{~N}_{2} \\
(\mathrm{AW}-101)\end{array}$ & air & & $42 \%$ & $68-106$ \\
\hline $\begin{array}{l}47 \% \mathrm{H}_{2}, 0.02 \% \mathrm{NH}_{3}, 19 \% \\
\mathrm{~N}_{2} \mathrm{O}, 0.9 \% \mathrm{CH}_{4}, 33 \% \mathrm{~N}_{2} \\
(\mathrm{AN}-104)\end{array}$ & air & & $\begin{array}{l}40 \% \\
54 \%\end{array}$ & $\begin{array}{l}8-14 \\
9-17\end{array}$ \\
\hline $\begin{array}{l}61 \% \mathrm{H}_{2}, 0.05 \% \mathrm{NH}_{3}, \\
3.8 \% \mathrm{~N}_{2} \mathrm{O}, 0.01 \% \mathrm{CH}_{4}, \\
35 \% \mathrm{~N}_{2} \\
\text { (AN-103) }\end{array}$ & air & & $\begin{array}{l}58 \% \\
65 \%\end{array}$ & $\begin{array}{c}5-16 \\
19-42\end{array}$ \\
\hline $\begin{array}{l}63 \% \mathrm{H}_{2}, 0.02 \% \mathrm{NH}_{3}, 11 \% \\
\mathrm{~N}_{2} \mathrm{O}, 0.7 \% \mathrm{CH}_{4}, 25 \% \mathrm{~N}_{2} \\
(\mathrm{AN}-105)\end{array}$ & air & & $\begin{array}{l}54 \% \\
59 \%\end{array}$ & $\begin{array}{l}7-14 \\
7-14\end{array}$ \\
\hline $\begin{array}{l}75 \% \mathrm{H}_{2}, 2.4 \% \mathrm{NH}_{3}, 5.6 \% \\
\mathrm{~N}_{2} \mathrm{O}, 0.7 \% \mathrm{CH}_{4}, 16 \% \mathrm{~N}_{2} \\
(\mathrm{~A}-101)\end{array}$ & air & & $\begin{array}{l}62 \% \\
68 \%\end{array}$ & $\begin{array}{l}8-14 \\
7-20\end{array}$ \\
\hline
\end{tabular}

\subsection{Detonation Within Waste}

The potential for detonation in the pore space of tank waste is defined by the detonation cell width of the gas itself and by the pore diameter. The same physical arguments that made it impossible for pores that were open to the air to hold enough gas to support deflagration also apply to detonation (Slezak et al. 1998). Therefore, the gas must be capable of supporting detonation under airless conditions

As was the case for deflagrations, detonations cannot propagate within pores or from an open space into pores when the pore diameter is less than a certain critical value. The critical (minimum) diameter has been assumed ${ }^{(a)}$ to be the same as for propagation from a pipe into an open space, $d_{c}>13 \lambda$ (Eq. 4.2).

(a) Pfahl U, JE Shepherd, and C Unal. February 23, 1998. Combustion Within Porous Waste. Report FM97-18, Explosion Dynamics Laboratory, Pasadena, California. 
Of the mixtures that were used to simulate gas retained in tank waste (see Table 4.2 for a list), only one had the detonation cell width measured at $0 \%$ air dilution. This SY-101 gas simulant $\left(29 \% \mathrm{H}_{2}, 11 \% \mathrm{NH}_{3}, 24 \% \mathrm{~N}_{2} \mathrm{O}, 1 \% \mathrm{CH}_{4}, 35 \% \mathrm{~N}_{2}\right)$ is somewhat less fuel-rich than the retained gas that was subsequently measured by RGS $\left(34 \% \mathrm{H}_{2}, 19 \% \mathrm{NH}_{3}, 19 \% \mathrm{~N}_{2} \mathrm{O}, 0.6 \% \mathrm{CH}_{4}\right.$, $27 \% \mathrm{~N}_{2}$ ). The cell width for the retained gas could therefore be somewhat smaller than that measured for the simulant, 19 to $35 \mathrm{~mm}$ (Table 4.2). However, the critical diameter for propagation ( 260 to $460 \mathrm{~mm}$ ) is so much greater than the expected size of pores, networks, or fractures in the waste that a slightly smaller critical diameter would not change the conclusion that detonation cannot propagate within the SY-101 matrix.

A reaction model, calibrated using the cell widths measured at high dilution, ${ }^{(a)}$ was used to estimate the cell widths for undiluted mixtures representing gases in A-101, AN-103, AN-104, $\mathrm{AN}-105$, and $\mathrm{AW}-101$. The results showed that there was too little $\mathrm{N}_{2} \mathrm{O}$ in the gas simulants for $\mathrm{AW}-101, \mathrm{AN}-103$, and A-101 to allow a detonation in the undiluted gas. In the AN-104 mixture $\left(19 \% \mathrm{~N}_{2} \mathrm{O}\right)$ the cell width was calculated to be about $80 \mathrm{~mm}$, and, in the AN-105 mixture (11\% $\mathrm{N}_{2} \mathrm{O}$ ), $4000 \mathrm{~mm}$. Here again, the critical diameter $13 \lambda$ for detonation propagation is much higher than any plausible passage size.

Of the tanks whose gases were not simulated, several (according to Table 3.3) retained gas that contained $\mathrm{H}_{2}$ and $\mathrm{N}_{2} \mathrm{O}$ that were comparable to the gas simulants for $\mathrm{AN}-104$ and $\mathrm{AN}-105$. This group included AX-101 $\left(60 \% \mathrm{H}_{2}, 11 \% \mathrm{~N}_{2} \mathrm{O}\right), \mathrm{BY}-109\left(50 \% \mathrm{H}_{2}, 18 \% \mathrm{~N}_{2} \mathrm{O}\right), \mathrm{S}-106\left(63 \% \mathrm{H}_{2}\right.$, $\left.11 \% \mathrm{~N}_{2} \mathrm{O}\right)$, and $\mathrm{S}-111\left(66 \% \mathrm{H}_{2}, 11 \% \mathrm{~N}_{2} \mathrm{O}\right)$. It seems likely that cell widths at $0 \%$ air dilution would be at least 50 to $100 \mathrm{~mm}$ for these gases, though this estimate is uncertain and a reaction zone model would be needed to provide a better estimate. Part of the uncertainty comes from the compositions of the gases, part from the fact that the gases are retained at hydrostatic pressures of $1.5 \mathrm{~atm}$ or more. The higher initial pressure would be expected to reduce the cell width, compared to 1-atm measurements.

Tanks S-102 (33\% $\left.\mathrm{H}_{2}, 33 \% \mathrm{~N}_{2} \mathrm{O}\right)$, SX-106 (51\% $\left.\mathrm{H}_{2}, 24 \% \mathrm{~N}_{2} \mathrm{O}\right), \mathrm{U}-103\left(23 \% \mathrm{H}_{2}, 40 \% \mathrm{~N}_{2} \mathrm{O}\right)$, and U-109 $\left(25 \% \mathrm{H}_{2}, 27 \% \mathrm{~N}_{2} \mathrm{O}\right)$ contained much more $\mathrm{N}_{2} \mathrm{O}$ and more closely resembled the gas simulant for SY-101. The SY-101 gas simulant had a cell width of 19 to $35 \mathrm{~mm}$ at airless conditions and $1 \mathrm{~atm}$. Again, using this cell width for other (though similar) compositions introduces much uncertainty. However, because the critical diameter is $13 \lambda$, even the minimum $\lambda$ measured for nitrogen-containing gas mixtures (about $7.5 \mathrm{~mm}$, for a mixture of $28 \% \mathrm{H}_{2}, 42 \%$ $\mathrm{N}_{2} \mathrm{O}, 30 \% \mathrm{~N}_{2}$, similar to U-103 gas) still implies that a crack of $98 \mathrm{~mm}$ (about 4 in.) diameter would be required for detonation propagation.

Not only would a crack in waste need to be of a large diameter throughout its length, but the length of the crack would probably need to be at least 10 times the diameter for a detonation to make the transition to a detonation. Our conclusion is that detonation propagation is not plausible in the tanks whose retained gas compositions have been measured.

(a) Pfahl U, JE Shepherd, and C Unal. February 23, 1998. Combustion Within Porous Waste. Report FM97-18, Explosion Dynamics Laboratory, Pasadena, California. 


\subsection{Conclusions}

The following conclusions were drawn from the deflagration and detonation research summarized above:

- When the fuel concentration in air was at or above the downward propagation LFL, deflagrations of waste gas mixtures typically produced peak pressures of $80 \%$ to $90 \%$ of the pressure predicted for adiabatic, isochoric complete combustion. The AICC pressure can therefore be used as a slightly conservative representation of actual pressures resulting from a burn.

- Peak pressures from deflagrations of waste gases were usually four or more times the initial pressure and were less than 10 times the initial pressure in all the measurements made with air as the primary oxidant.

- The presence of $\mathrm{N}_{2} \mathrm{O}$ increased the peak pressures of deflagrations, while $\mathrm{N}_{2}$ significantly reduced the peak pressure.

- Deflagrations are unlikely to propagate within Hanford wastes because retained gas does not appear to take the form of millimeter-diameter pores interconnected in a large network. Creating an ignition source within the waste is also problematic. However, small-scale deflagrations involving fracture bubbles of several $\mathrm{cm}$ extent or bubble networks of up to $1 \mathrm{~m}$ extent cannot be ruled out.

- $\mathrm{NH}_{3}$ and $\mathrm{CH}_{4}$ reduced the detonability of $\mathrm{H}_{2} / \mathrm{N}_{2} \mathrm{O}$ mixtures.

- Dilution of 65 to $80 \%$ air or $\mathrm{N}_{2}$ was sufficient to give detonation cell widths of $100 \mathrm{~mm}$ for all stoichiometric fuel/oxidizer combinations except $\mathrm{NH}_{3} / \mathrm{O}_{2}$, for which $35 \%$ dilution with $\mathrm{N}_{2}$ sufficed. However, fuel-rich mixtures (such as the simulated gases for AN-103 and A-101) had cell widths well below $100 \mathrm{~mm}$ when diluted $65 \%$ by air.

Detonations will not propagate within the RGS-sampled Hanford wastes; the same conditions that make deflagration unlikely make detonation implausible. 



\subsection{Ignition}

The preceding sections show that some of the gas mixtures created within the waste and released to the headspace of the tank are indeed flammable. If these gases were allowed to collect without dilution, ignition could result in a deflagration or detonation. This section evaluates the requirements for initiating a burn of flammable gases.

\section{Requirements for Ignition}

Mechanisms for ignition of a given mixture of combustible gases are complex and involve formation of a critical concentration of molecular fragments by the energy in electrostatic or mechanical sparks. Several energy sources and configurations have been used to study flame ignition. It has been determined that an ordinary capacitor discharge spark consistently yields the lowest ignition energy for any specific combustible mixture (Strehlow 1984). Therefore, experiments that use capacitive spark discharge may (conservatively) underestimate the ignition energy that would be required for ignition if supplied by less effective energy sources.

Studies of the requirements for ignition of hydrogen have defined the "minimum ignition energy" (MIE), the energy below which the ignition of a combustible mixture cannot occur and above which ignition occurs. Most of the work on minimum ignition energies was done with capacitive spark discharges. For hydrogen the MIE is on the order of $0.01 \mathrm{~mJ}$ (Pratt 1997). To put this in perspective, the range of energies in sparks from static discharges perceived by humans can range from microjoules to tens of millijoules. A $1 \mathrm{~mJ}$ spark is perceptible, a $10 \mathrm{~mJ}$ spark is a prick, a $30 \mathrm{~mJ}$ spark is a sharp prick, and a $100 \mathrm{~mJ}$ spark will result in a slight jerk (Pratt 1997). Thus, the sparks from humans touching metal far exceed the energy required to ignite some hydrogen/air mixtures.

The MIE for a gas varies with the stoichiometry of the mixture, as shown for benzene in Figure 5.1 (Britton 1992). The optimum concentration that gives the lowest MIE (LMIE) is not the stoichiometric fuel/oxidant mixture but a slightly fuel-rich one. The MIE at the LFL is several orders of magnitude greater than that for the optimum mixture. This same situation exists for hydrogen-oxygen systems (Lewis and Elbe 1987, p. 347), as shown in Figure 5.2. The MIE is about $0.02 \mathrm{~mJ}$ for $\mathrm{H}_{2}-\mathrm{O}_{2}-\mathrm{N}_{2}$ at $25-30 \%$ hydrogen. At $5 \% \mathrm{H}_{2}$ the MIE is greater than $1 \mathrm{~mJ}$.

Because the gas mixtures of interest to the Flammable Gas Safety Issue might behave differently than the individual components, an experiment was conducted at the California Institute of Technology ${ }^{(a)}$ to evaluate the effect of various ignition energies on the LFL of mixtures relevant to Hanford tank waste gases containing $\mathrm{H}_{2}, \mathrm{NH}_{3}, \mathrm{~N}_{2} \mathrm{O}, \mathrm{CH}_{4}$, and $\mathrm{N}_{2}$. The researchers found that, for ignition energies less than $10 \mathrm{~J}$, the flammability limit (in air) of Mixtures $27\left(40 \% \mathrm{H}_{2}, 40 \% \mathrm{~N}_{2} \mathrm{O}, 20 \% \mathrm{CH}_{4}\right), 28\left(35 \% \mathrm{H}_{2}, 35 \% \mathrm{~N}_{2} \mathrm{O}, 10 \% \mathrm{CH}_{4}, 20 \% \mathrm{NH}_{3}\right)$, and $29\left(29 \% \mathrm{H}_{2}, 24 \% \mathrm{~N}_{2} \mathrm{O}, 11 \% \mathrm{NH}_{3}, 35 \% \mathrm{~N}_{2}, 1 \% \mathrm{CH}_{4}\right)$ occurred at $7 \%, 9 \%$, and $14 \%$ fuel in air, respectively. None of the three mixtures showed any pronounced dependence of the LFL on ignition energy between 0.04 and $8 \mathrm{~J}$.

(a) Pfahl U and JE Shepherd. 1997. Flammability, Ignition Energy, and Flame Speeds in NH3-H2-CH4N2O-O2-N2 Mixtures. Report FM97-4R1, Explosion Dynamics Laboratory, Pasadena, California. 


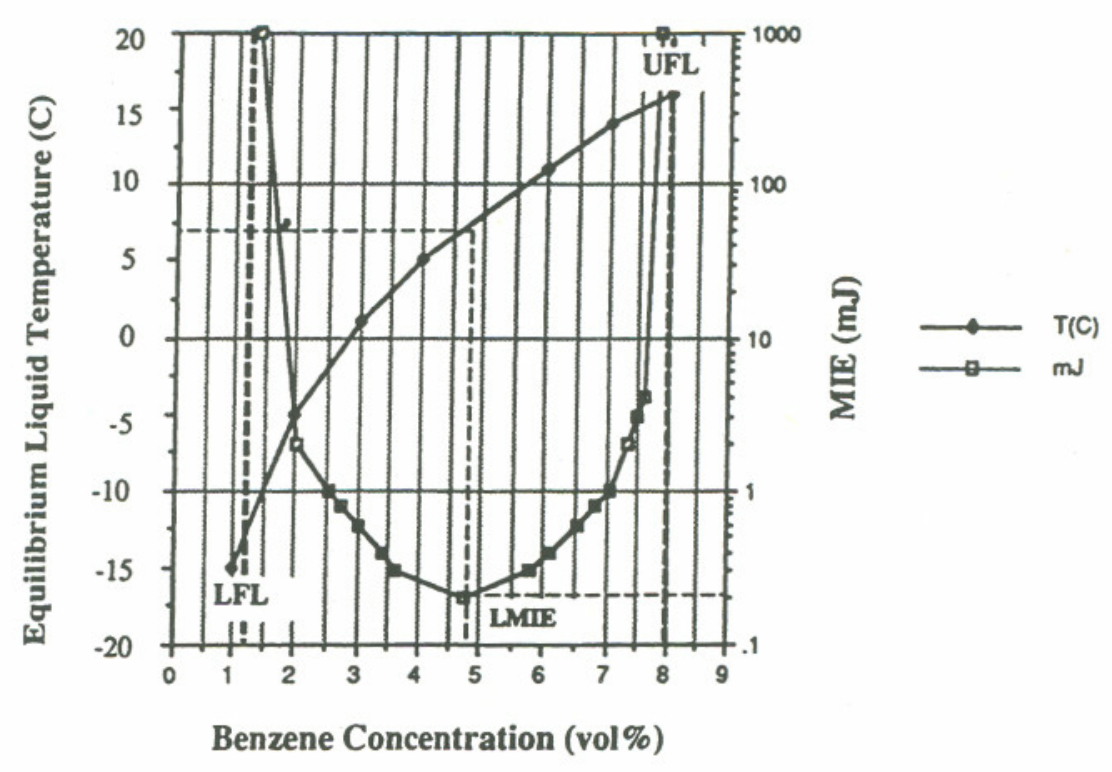

Figure 5.1. Typical Relationship Between Stoichiometry and Minimum Ignition Energy (Britton 1992)

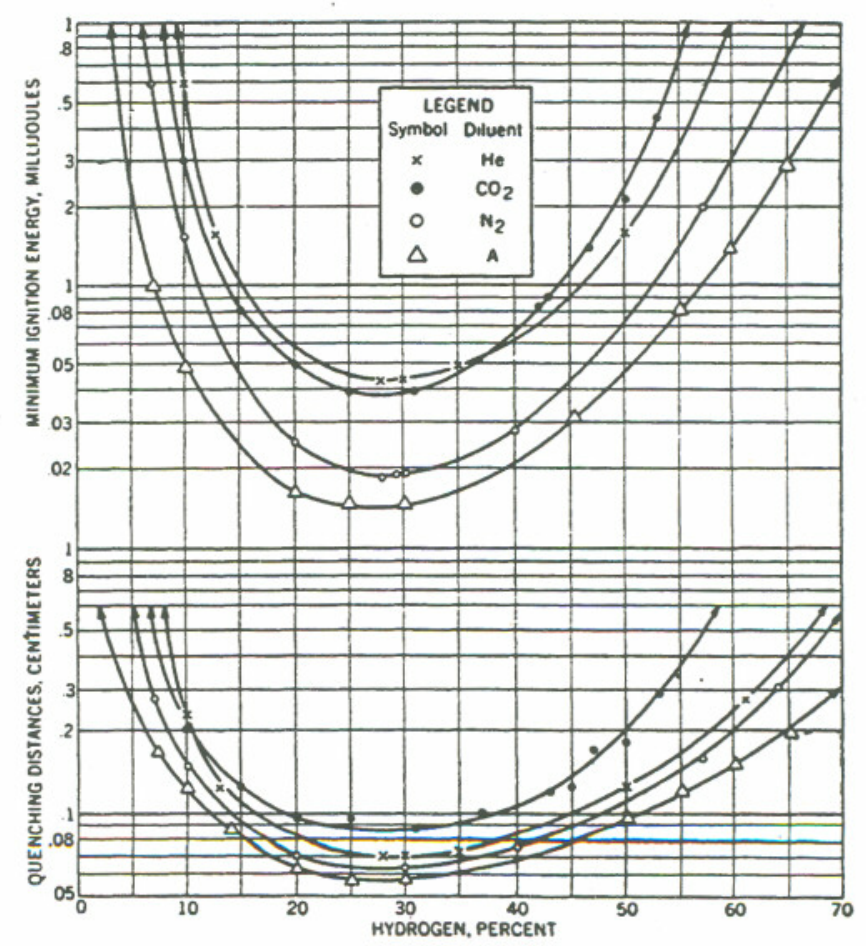

Figure 5.2. Relationship Between Stoichiometry and Minimum Ignition Energy for $\mathrm{H}_{2} / \mathrm{O}_{2} /$ Inert (Lewis and Elbe 1987) 
Friction sparks that result from the impact of two surfaces can serve as an ignition source for flammable gas mixtures. The temperature of a spark struck from steel can approach $1400^{\circ} \mathrm{C}$. The ignition potential of a spark depends upon its total heat content; thus the size of the particle produced is an important factor. Mechanical sparks cool quickly and can ignite gases only under very favorable conditions. A study was done to determine which metal would be best suited for use in Tank 241-SY-101 (Pearce 1992, p. 45-57). The study showed that hot-spot temperatures achieved by normal or glancing blows were less than the temperature required to ignite hydrogen-air mixtures; that the presence of rust made ignition more likely; and that stainless steel was one of the most sparking-resistant materials available. The results of this work led to using stainless steel for new components in Tank 241-SY-101 and other similar tanks. In addition, special tools of copper-beryllium and other low-sparking alloys are being used at the Hanford Site to minimize the danger of sparks in hazardous locations.

Flammable gas mixtures can be ignited by a hot surface. The minimum temperature at which a mixture will burst into flame spontaneously is known as the auto-ignition temperature (AIT). The AIT is typically measured in air. Some typical values are $520^{\circ} \mathrm{C}$ for hydrogen, $650^{\circ} \mathrm{C}$ for ammonia, and $630^{\circ} \mathrm{C}$ for methane (Kuchta 1985). An evaluation was conducted at $\mathrm{CIT}^{(\mathrm{a})}$ for gas mixtures relevant to the Hanford tanks. For $\mathrm{H}_{2}-\mathrm{N}_{2} \mathrm{O}-\mathrm{NH}_{3}$ mixtures, the investigators estimated the AIT to be in the range of $457^{\circ}$ to $507^{\circ} \mathrm{C}$. Procedural protections restrict welding and other activities that might produce such high surface temperatures.

The dome spaces of the Hanford tanks are connected to the ambient environment via filtered ventilation systems. Due to the water content of the waste and the humidity of the inlet air, the dome spaces have a reasonably high relative humidity; that is, the atmosphere in the headspace is not dry. The relative humidity can range from 20 to $60 \%$. As noted in Section 3.3, the humidity does not have a significant effect on the LFL of gas mixtures in which hydrogen is the main contributor; however, high humidity could be expected to reduce the sparking potential of some materials.

In summary, ignition of flammable mixtures that contain hydrogen as the principal component can occur at very low levels of energy for electrostatic sparks. Accordingly, the operating controls for the tank farms at the Hanford Site incorporate controls for ignition sources and for monitoring flammable gases.

(a) Shepherd JE and MC Ross. April 11, 1995. "Explosion Hazard Evaluation for a Sample Container." Letter to Los Alamos National Laboratory from Graduate Aeronautical Laboratories, California Institute of Technology, Pasadena, California. 



\subsection{References}

Abbud-Madrid A and PD Ronney. 1990. "Effects of Radiative and Diffuse Transport Processes on Premixed Flames near Flammability Limits." Proceedings of $23^{\text {rd }}$ Symposium on Combustion, pp. 423-431. The Combustion Institute, Pittsburgh, Pennsylvania.

Antoniak ZI and KP Recknagle. 1997. Initial Parametric Study of the Flammability of Plume Releases in Hanford Waste Tanks. PNNL-11639, Pacific Northwest National Laboratory, Richland, Washington.

Ashby EC, EK Barefield, CL Liotta, and HM Neumann. 1992. Hanford Tank Safety Minutes of the Tank Waste Science Panel Meeting, March 24-27, 1992. WW Schultz and DM Strachan, eds. PNL-8278, Pacific Northwest Laboratory, Richland, Washington.

Ashby EC, F Doctorovich, CL Liotta, HM Neumann, EK Barefield, A Konda, K Zhang, J Hurley, and DD Siemer. 1993. "Concerning the Formation of Hydrogen in Nuclear Waste: Quantitative Generation of Hydrogen via a Cannizzaro Intermediate." J. American Chemical Society, 115:1171.

Ashby EC, A Annis, EK Barefield, D Boatright, R Doctorovich, CL Liotta, HM Neumann, CF Yao, K Zhang, and NF McDuffie. 1994. Synthetic Waste Chemical Mechanism Studies. WHC-EP-0823, Westinghouse Hanford Company, Richland, Washington.

Barefield EK, D Boatright, A Desphande, R Doctorovich, CL Liotta, HM Neumann, and S Seymore. 1995. Mechanisms of Gas Generation from Simulated SY Tank Farm Wastes: FY 1994 Progress Report. PNL-10822, Pacific Northwest Laboratory, Richland, Washington.

Barefield EK, D Boatright, A Desphande, R Doctorovich, CL Liotta, HM Neumann, and S Seymore. 1996. Mechanisms of Gas Generation from Simulated SY Tank Farm Wastes: FY 1995 Progress Report. PNL-11247, Pacific Northwest National Laboratory, Richland, Washington.

Barker SA, WB Barton, DR Bratzel, M Epstein, PA Gauglitz, GD Johnson, SN Maruvada, CE Olson, ML Sauer, SE Slezak, CW Stewart, and J Young. 1999. Flammable Gas Safety Analysis Data Review. SNL-000198, Sandia National Laboratories, Albuquerque, New Mexico.

Breshears WD. 1995. "Falloff Behavior in the Thermal Dissociation Rate of $\mathrm{N}_{2} \mathrm{O}$." J. Phys. Chem. 99, 12529-12535.

Breshears WD, HA Fry, JL Lyman, RC Oldenbort, and DK Zerkle. 1997. Final Report: Gas Flammability Modeling. LA-UR-97-2206, Los Alamos National Laboratory, Los Alamos, New Mexico.

Britton LG. 1992. "Using Material Data in Static Hazard Assessment." Plant/Operations Progress 7(2):56-70. 
Bryan SA and LR Pederson. 1994. Composition, Preparation, and Gas Generation Results from Simulated Wastes of Tank 241-SY-101. PNL-10075, Pacific Northwest Laboratory, Richland, Washington.

Bryan SA and LR Pederson. 1995. Thermal and Combined Thermal and Radiolytic Reactions Involving Nitrous Oxide, Hydrogen, and Nitrogen in the Gas Phase; Comparison of Gas Generation Rates in Supernate and Solid Fractions of Tank 241-SY-101 Simulated Waste. PNL10490, Pacific Northwest Laboratory, Richland, Washington

Bryan SA, LR Pederson, RD Scheele, and SR Adami. 1993. Proceedings of the $4^{\text {th }}$ Annual International Conference on High-Level Radioactive Waste Management, Vol. 2, p. 1348. American Nuclear Society, Las Vegas, Nevada.

Buckley WL and HW Husa. 1962. "Combustion Properties of Ammonia." Chemical Engineering Progress, Vol. 58, pp. 81-84.

Calcote HF, JCA Gregory, CM Barnett, and RB Gilmer. 1952. "Spark Ignition." Industrial and Engineering Chemistry 44(11):2656-2662.

Camaioni DM, WD Samuels, JC Lenihan, AK Sharma, MO Hogan, MA Lilga, SA Clauss, KL Wahl, and JA Campbell. 1997. Organic Tanks Safety Program FY97 Waste Aging Studies. PNL-10794, Pacific Northwest National Laboratory, Richland, Washington.

Cannon NS and RC Knight. November 1995. Retained Gas Sampler System Acceptance Test Report. WHC-SD-WM-ATR-137 Rev. 0, Westinghouse Hanford Company, Richland, Washington.

Cannon NS. 1996. Retained Gas Sampler System Acceptance Test Report. WHC-SD-WMATR-137 Rev. 1, Westinghouse Hanford Company, Richland, Washington.

Cashdollar KL, M Hertzberg, IA Zlochower, CE Lucci, GM Green and RA Thomas. 1992. Laboratory Flammability Studies of Mixtures of Hydrogen, Nitrous Oxide, and Air. WHC-SDWM-ES-219, Westinghouse Hanford Company, Richland, Washington.

Coward HF and GW Jones. 1952. United States Bureau of Mines Bulletin 503.

CRC. 1990. CRC Handbook of Chemistry and Physics, 71st Edition, DR Lide, ed. CRC Press, Boston.

Delegard CH. 1980. Laboratory Studies of Complexed Waste Slurry Volume Growth in Tank 241-SY-101. RHO-LD-124, Rockwell Hanford Operations, Richland, Washington. Epstein M. 1995. Turbulent Free-Convection Mixing in a Tank Headspace. FAI/95-63, Fauske
\& Associates, Inc., Burr Ridge, Illinois. 
Epstein M and JP Burelbach. 1998. Experimental and Theoretical Turbulent Diffusion Modeling of Light Gas Releases in a Tank Headspace: 2. Local Releases. FAI/98-50, Fauske \& Associates, Inc., Burr Ridge, Illinois.

Fenton DL, RD Kelley, AS Khan, and KS Chapman. 1995. "Combustion Characteristics: Review of Ammonia-Air Mixtures.” ASHRAE Transactions, Vol. 101, pp. 476-485.

Hedengren DC, JD Bingham, SA Barker, JM Connor, and SD Estey. 1997. Calculation of Flammable Gas Mixtures in Double-Contained Receiver Tanks. HNF-SD-WM-CN-118, Lockheed Martin Hanford Corp., Richland, Washington.

Hertzberg M. 1976. "The Theory of Flammability Limits, Natural and Convection." Bureau of Mines Report of Investigation, V8127, pp. 1-15.

Huckaby JL, JA Edwards, JC Evans, JS Fruchter, JL Julya, KB Olsen, KH Pool, BL Thomas, KL Silvers, L Jensen, LL Buckley, SR Wilmarth, and LD Pennington. 1996. Comparison of Vapor Sampling System (VSS) and In Situ Vapor Sampling (ISVS) Methods on Tanks C-107, BY-108, and S-102. PNNL-11186, Pacific Northwest National Laboratory, Richland, Washington.

Huckaby JL, KB Olsen, DS Sklarew, JC Evans, and KM Remund. 1997a. Measurements of Waste Tank Passive Ventilation Rates Using Tracer Gases. PNNL-11683, Pacific Northwest National Laboratory, Richland, Washington.

Huckaby JL, JC Hayes, L Jensen, LL Buckley, RD Cromar, LD Pennington, and SR Wilmarth. 1997b. Homogeneity of Passively Ventilated Waste Tanks. PNNL-11640, Pacific Northwest National Laboratory, Richland, Washington.

Huckaby JL, JC Evans, DS Sklarew, and AV Mitroshkov. 1998. Waste Tank Ventilation Rates Measured with a Tracer Gas Method. PNNL-11925, Pacific Northwest National Laboratory, Richland, Washington.

Johnson GD. 1997. Flammable Gas Program Topical Report. WHC-SP-1193 Rev. 2, Westinghouse Hanford Company, Richland, Washington

Jones E and Kerr JC. 1949. "Inflammability Limits of Ammonia, Nitrous Oxide, and Air." J.S.C.I 68:31.

King CM, SA Bryan, and LR Pederson. 1997. Gas Generation from Tank 241-S-102. PNNL11600 , Pacific Northwest National Laboratory, Richland, Washington.

King CM and SA Bryan. 1999. Thermal and Radiolytic Gas Generation Tests on Material from Tanks 241-U-103, 241-AW-101, 241-S-106, and 241-S-102: Status Report. PNNL-12181, Pacific Northwest National Laboratory, Richland, Washington. 
Kuchta JM. 1985. "Investigation of Fire and Explosion Accidents in the Chemical, Mining, and Fuel-Related Industries-A Manual.” Bulletin \#680, United States Bureau of Mines, Washington, D.C.

Lewis B and G Von Elbe. 1961. Combustion, Flames, and Explosions of Gases. Academic Press, New York.

Los Alamos National Laboratory. 1994. A Safety Assessment for Proposed Pump Mixing Operations to Mitigate Episodic Gas Releases in Tank 241-SY-101. LA-UR-92-3196 Rev. 9, Los Alamos National Laboratory, Los Alamos, New Mexico.

Lyamin GA and AV Pineav. 1985. "Supersonic (detonation) combustion of gases in inert porous media." Sov. Phys. Dokl. 30: 694-696.

Mahoney LA and DS Trent. 1995. Correlation Models for Waste Tank Sludges and Slurries. PNL-10695, Pacific Northwest Laboratory, Richland, Washington.

Mahoney LA, ZI Antoniak, JM Bates, and ME Dahl. 1999. Retained Gas Sampling Results for the Flammable Gas Program. PNNL-13000, Pacific Northwest National Laboratory, Richland, Washington.

McCain DJ. 1999. Results of Vapor Space Monitoring of Flammable Gas Watch List Tanks. HNF-SD-WM-TI-797 Rev. 4, Lockheed Martin Hanford Corp. for Fluor Daniel Hanford, Inc., Richland, Washington.

Meisel D, H Diamond, EP Horowitz, CD Jonah, MS Matheson, MC Sauer, and JC Sullivan. 1991a. Radiation Chemistry of Synthetic Waste. ANL-91/40, Argonne National Laboratory, Argonne, Illinois.

Meisel D, H Diamond, EP Horowitz, MS Matheson, MC Sauer, JC Sullivan, F Barnabas, E Cerny, and YD Cheng. 1991b. Radiolytic Generation of Gases from Synthetic Waste. ANL91/40, Argonne National Laboratory, Argonne, Illinois.

Meisel D, CD Jonah, MS Matheson, MC Sauer, JC Sullivan, F Barnabas, E Cerny, YD Cheng, and T Wojta. 1992. Radiation Chemistry of High Level Waste. ANL-91/40, Argonne National Laboratory, Argonne, Illinois.

Meisel D, CD Jonah, S Kapoor, MS Matheson, and MC Sauer. 1993. Radiolytic and Radiolytically Induced Generation of Gases from Synthetic Wastes. ANL-93/43, Argonne National Laboratory, Argonne, Illinois.

Meyer PA, ME Brewster, SA Bryan, G Chen, LR Pederson, CW Stewart, and G Terrones. 1997. Gas Retention and Release Behavior in Hanford Double-Shell Waste Tanks. PNNL-11536 Rev. 1, Pacific Northwest National Laboratory, Richland, Washington. 
Norton JD and LR Pederson. 1994. Ammonia in Simulated Hanford Double-Shell Tank Wastes: Solubility and Effects on Surface Tension. PNL-10173, Pacific Northwest Laboratory, Richland, Washington.

Norton JD and LR Pederson. 1995. Solubilities of Gases in Simulated Tank 241-SY-101 Wastes. PNL-10785, Pacific Northwest Laboratory, Richland, Washington.

Pacific Northwest National Laboratory. March 31, 1999. Tank Characterization Database, Version 3.22.

Pearce KL. 1992. 101-SY Gas Monitor System Sample Probe Design Support Analysis. WHCSD-WM-DA-077, Westinghouse Hanford Company, Richland, Washington.

Pederson LR and SA Bryan. 1996. Status and Integration of Studies of Gas Generation in Hanford Waste. PNNL-11297, Pacific Northwest National Laboratory, Richland, Washington.

Person JC. 1996. Effects of Oxygen Cover Gas and NaOH Dilution on Gas Generation in 241-SY-101 Waste. WHC-SD-WM-DTR-043, Westinghouse Hanford Company, Richland, Washington.

Pratt TH. 1997. Electrostatic Ignitions of Fires and Explosions. Burgoyne Incorporated.

Ronney PD. 1987. "Effect of Chemistry and Transport Properties on Near Limit Flames at Microgravity." Combustion Science and Technology, Vol. 59, pp. 123-141.

Shekarriz A. 1994. Retained Gas Sampler Flow Visualization Guide. PNL-10138, Pacific Northwest Laboratory, Richland, Washington.

Siciliano ER. 1998. Drill String Gas Data. HNF-1754 Rev. 0, Fluor Daniel Northwest, Inc., Richland, Washington.

Slezak SE, DC Williams, W Cheng, F Gelbard, DR Bratzel. 1998. Refined Safety Analysis Methodology for Flammable Gas Risk Assessment in the Hanford Site Tanks. HNF-SD-WMES-410 Rev. 2, Fluor Daniel Hanford, Inc., Richland, Washington.

Smith S and JW Linnett. 1953. J. Chem Soc London, Part 1, pp. 37-43.

Spalding DB. 1957. "A Theory of Inflammability Limits and Flame Quenching." Proc. Royal Soc. (London) Series A., Vol. 240, p. 83.

Stewart CW, ME Brewster, PA Gauglitz, LA Mahoney, PA Meyer, KP Recknagle, and HC Reid. 1997. Gas Retention and Release Behavior in Hanford Single-Shell Waste Tanks. PNNL-11536 Rev. 1, Pacific Northwest National Laboratory, Richland, Washington.

Strehlow RA. 1984. Combustion Fundamentals. McGraw-Hill Book Company, New York. 
Trimis D and F Durst. 1996. "Combustion in a porous medium-advances and applications." Combust. Sci. and Tech. 121: 153-168.

Webb BJ. 1994. Summary Report on the Design of the Retained Gas Sampler System. WHCSO-WM-ER-387, Westinghouse Hanford Company, Richland, Washington.

Zabetakis MG. 1965. The Flammability Characteristics of Combustible Gases and Vapors. United States Bureau of Mines Bulletin 627.

Zalosh RG. 1988. "Explosion Protection." SFPE Handbook of Fire Protection Engineering, $1^{\text {st }}$ Edition. National Fire Protection Association, Quincy, Massachusetts. 


\section{Distribution}

No. of

Copies

\section{Offsite}

2 DOE Office of Scientific and Technical Information

C. S. Abrams

2270 Henryanna Ave.

Idaho Falls, ID 83404

H. Babad

2540 Cordoba Ct.

Richland, WA 99352

D. O. Campbell

102 Windham Road

Oak Ridge, TN 37830

P. d'Entremont

Savannah River Site

Aiken, SC 29802

C. W. Forsberg

Oak Ridge National Laboratory

P.O. Box 2008, MS-6495

Oak Ridge, TN 37831-6495

B. C. Hudson

P.O. Box 271

Lindsborg, KS 67456

M. W. First

295 Upland Ave.

Newton Highland, ME 02161

J. Jackson

Lawrence Livermore National Laboratory

P.O. Box 808 , L-382

Livermore, CA 94551-0808
No. of

$\underline{\text { Copies }}$

M. S. Kazimi

Massachusetts Institute

of Technology

Department of Nuclear Engineering

77 Massachusetts Avenue

Cambridge, MA 02139

J. L. Kovach

P.O. Box 29151

Columbus, OH 43229

T. S. Kress

102-B Newridge Road

Oak Ridge, TN 37830

W. L. Kubic

Los Alamos National Laboratory

P.O. Box 1663

Los Alamos, NM 87545

T. E. Larson

2711 Walnut St.

Los Alamos, NM 87544

D. T. Oakley

9612 Hall Rd.

Potomac, MD 20854

D. A. Powers

Sandia National Laboratory

Nuclear Facilities Safety Department

MS-0744

Albuquerque, NM 87185-0744

G. E. Schmauch

6842 Linden Circle

Macumgie, PA 18062 
No. of

$\underline{\text { Copies }}$

Offsite

S. E. Slezak

806 Hermosa NE

Albuquerque, NM 87110

L. M. Stock

6695 SW 86 ${ }^{\text {th }}$ Ave.

Portland, OR 97223
No. of

Copies

D.C. Hedengren

R2-11

K. M. Hodgson

R2-11

T. A. Hu

R2-11

G. D. Johnson (3)

R1-44

N. W. Kirch

R2-11

L. J. Kripps

R1-44

C. E. Leach

R1-44

D.J. McCain

R2-11

R. E. Raymond

S7-70

D. A. Reynolds

R2-11

\section{Onsite}

4 DOE Office of River Protection

$\begin{array}{ll}\text { C. A. Groendyke } & \text { H6-60 } \\ \text { J.-S. Shuen } & \text { H6-60 } \\ \text { D. H. Irby } & \text { H6-60 } \\ \text { Y. G. Noorani } & \text { H6-60 }\end{array}$

18 PHMC Team
S. A. Barker
W. B. Barton
R. E. Bauer
C. Carro
R. J. Cash
J. M. Grigsby

R1-44

$\mathrm{R} 2-11$

S7-70

R1-44

R1-44

R1-44

29 Pacific Northwest National Laboratory

J. M. Bates

K7-15

S. Q. Bennett

J. W. Brothers (5)

S. A. Bryan

J. A. Fort

P. A. Gauglitz

J. L. Huckaby

L. A. Mahoney (10)

P. A. Meyer

L.M. Peurrung

C. W. Stewart

Information Release (5)
K7-90

K9-20

P7-25

K7-15

K6-28

$\mathrm{K} 7-15$

K7-15

K7-15

K6-24

K7-15

K1-06 